UNIVERSIDADE DE SÃO PAULO

FACULDADE DE ZOOTECNIA E ENGENHARIA DE ALIMENTOS

KARINA APARECIDA FIORETTI

A FORMAÇÃO NO ENSINO PROFISSIONALIZANTE NO SEGMENTO DO AGRONEGÓCIO: UM ESTUDO DE CASO NA ETEC AGRÍCOLA DE SANTA RITA DO PASSA QUATRO

PIRASSUNUNGA

2019 


\section{A FORMAÇÃO NO ENSINO PROFISSIONALIZANTE NO SEGMENTO DO AGRONEGÓCIO: UM ESTUDO DE CASO NA ETEC AGRÍCOLA DE SANTA RITA DO PASSA QUATRO \\ (VERSÃO CORRIGIDA)}

Dissertação de Mestrado apresentada à Faculdade de Zootecnia e Engenharia de Alimentos, da Universidade de São Paulo, como parte dos requisitos para obtenção do título de Mestrado em Ciências.

Área de Concentração: Gestão, Inovação na Indústria Animal

Orientador: Prof. Dr. Marcelo Machado De Luca de Oliveira Ribeiro 
Ficha catalográfica elaborada pelo Serviço de Biblioteca e Informação, FZEA/USP, com os dados fornecidos pelo(a) autor(a)

F518f Fioretti, Karina Ap

A formação no ensino profissionalizante no

segmento do agronegócio: Um estudo de caso na Etec

Agrícola de Santa Rita do Passa Quatro. / Karina Ap Fioretti; orientador Dr. Marcelo Machado De Luca de Oliveira Ribeiro. -- Pirassununga, 2019.

$91 \mathrm{f}$.

Dissertação (Mestrado - Programa de Pós-Graduação em Mestrado Profissional Gestão e Inovação na Indústria Animal) -- Faculdade de Zootecnia e Engenharia de Alimentos, Universidade de São Paulo.

1. Agronegócio. 2. Centro Paula Souza. 3. Educação Profissional. 4. Estado de São Paulo. 5. Estudantes Etecs Agrícolas. I. Ribeiro, Dr. Marcelo Machado De Luca de Oliveira, orient. II. Título. 


\section{A FORMAÇÃO NO ENSINO PROFISSIONALIZANTE NO SEGMENTO DO AGRONEGÓCIO: UM ESTUDO DE CASO NA ETEC AGRÍCOLA DE SANTA RITA DO PASSA QUATRO}

Data da aprovação:

Banca Examinadora:

Dissertação de Mestrado apresentada à Faculdade de Zootecnia e Engenharia de Alimentos, da Universidade de São Paulo, como parte dos requisitos para obtenção do título de Mestrado em Ciências.

Área de Concentração: Gestão, Inovação na Indústria Animal

Prof. Dr. Marcelo Machado de Luca de Oliveira Ribeiro - FZEA/USP Presidente da Banca Examinadora - Orientador

Prof. Dr. Cesar Gonçalves de Lima - FZEA/USP

Profa Dra. Catarina Abdalla Gomidi- FZEA/USP

Profa Dra. Maria Ângela Fagnani - UNICAMP 
Dedico essa dissertação à minha família: pai, mãe, irmão, afilhada, tia Cidinha, meu marido Cláudio e a saudosa vó Domingas. 


\section{AGRADECIMENTOS}

Primeiramente gostaria de agradecer a Deus, pelo dom da vida e saúde; aos meus pais, Jairo e Antônia, pelo amor incondicional, paciência, esforço e dedicação na minha educação.

Ao meu irmão, Juninho, pelo companheirismo e carinho demonstrado em todos os momentos da minha vida.

À minha saudosa avó Domingas e tia Cidinha que sempre rezaram e torceram por mim.

A todos meus queridos amigos de trabalho da Etec Manoel dos Reis Araújo, Santa Rita do Passa Quatro, que muito contribuíram para a confecção desta pesquisa, com documentos, correções e entrevistas, em especial, Clunes, Maria Salete, Ana Maria Andreghetto, Gustavo (biblioteca), Ana Júlia Rani, Maria Amélia, Dona Zenilde, Josiane, Walter Pizetta, Luís Carlos Pizetta e aos estudantes de todas as séries do curso de Agropecuária.

Ao meu marido Cláudio pela parceria, motivação, paciência e, principalmente, por me acompanhar nas aulas de sexta-feira à noite, ficando no estacionamento da faculdade esperando o termino do curso.

À Faculdade de Zootecnia e Engenharia de Alimentos e ao Programa de Mestrado Profissional em Gestão e Inovação na Indústria Animal pela excelência em minha formação e por possibilitar a quem trabalha o presente estudo.

E para finalizar, ao Professor Dr Marcelo, orientador, que me acolheu com muita paciência e dedicação, estimulando minha formação científica, meu eterno agradecimento pelo apoio, confiança e amizade. 
"A vida tem mais imaginação do que carregamos dentro dos nossos sonhos."

Cristóvão Colombo 
FIORETTI, Karina Ap. "A formação no ensino profissionalizante no segmento do agronegócio: Um estudo de caso na Etec Agrícola de Santa Rita do Passa Quatro". 2019. 91 f. Dissertação (Mestrado) - Faculdade de Zootecnia e Engenharia de Alimentos, Universidade de São Paulo, Pirassununga, 2019.

A História da educação profissional no Brasil pode ser compreendida a partir do desenvolvimento das forças produtivas enquanto superestrutura derivada das relações econômicas e, também, a partir das diversas formas de trabalho e cultura que os grupos sociais produzem. Nesse sentido, a educação profissional requer, além do domínio operacional de um determinado fazer, a compreensão do saber tecnológico, a valorização da cultura do trabalho e a mobilização dos valores necessários à tomada de decisões. A modernização do sistema de produção em vista das necessidades do mercado, implicou uma série de reformas, incialmente no que tange à prática profissional, na diligência política e nas relações sociais. Nesse sentido, a presente pesquisa pretende analisar as experiências vividas pela escola agrícola, do Centro Paula Souza, a ETEC Manoel dos Reis Araújo, Santa Rita do Passa Quatro, Estado de São Paulo, e suas contribuições para com a formação de mão de obra especializada, ou seja, busca-se verificar especificamente como os estudantes percebem a formação que recebem e o papel da instituição. Para tanto, será analisado, a partir das expectativas do estudante, o que esperam com relação à sua formação ao longo do curso, se as competências e habilidades adquiridas foram de encontro aos seus anseios, em vista do espaço que pretendem ocupar no mercado de trabalho. Sendo assim, acreditou-se na hipótese de que os recursos humanos formados, nessa instituição, interessam ao mercado de trabalho afim, o agronegócio. $O$ percurso metodológico da pesquisa está pautado em análises de dados quantitativos e qualitativos oferecidos pela Secretaria Tecnológica do Estado de São Paulo, pelas Escolas Técnicas do Centro Paula Souza, as ETECs e, em entrevistas com estudantes do $3^{\circ}$ ano, do Ensino Médio Integrado ao Técnico-ETIM, professores e matérias práticas (técnicas) e produtores rurais (locais), com finalidade de identificar o atual perfil do público alvo dessa instituição. Espera-se, com essa pesquisa, enriquecer o quadro historiográfico da educação profissionalizante do Estado de São Paulo, desenvolvendo um estudo das experiências da ETEC Agrícola, tanto da sua estrutura passada quanto da atual, discutindo a formação dos alunos a partir de suas expectativas de mercado e a possibilidade de inserção no agronegócio.

Palavras-chave: Agronegócio; Centro Paula Souza; Educação Profissional; Estado de São Paulo; Estudante; ETEC Agrícola. 


\section{ABSTRACT}

FIORETTI, Karina Ap. "Training in vocational education in the agribusiness segment: A case study at Etec Agrícola de Santa Rita do Passa Quatro ". 2019. 91 f. Dissertation (Master's) - - Faculdade de Zootecnia e Engenharia de Alimentos, Universidade de São Paulo, Pirassununga, 2019.

The history of professional education in Brazil can be understood from the development of the productive forces as the superstructure derived from economic relations, and also from the different forms of work and culture that social groups produce. In this sense, professional education requires, besides the operational domain of a particular task, the understanding of technological knowledge, the work culture valorization and the mobilization of the necessary values for decision making. The modernization of the production system in view of the market needs, implied a series of reforms, initially with regard to work itself, political diligence and social relations. In view of this, the present research intends to analyze the experiences lived in the agricultural school, of Centro Paula Souza, Etec Manoel dos Reis Araújo, in the city of Santa Rita do Passa Quatro, State of São Paulo and its contributions to the supply of skilled labor, that is, we will specially check the current student profile of this institution. For this purpose, it will be analyzed, based on the student's expectations, what he/she expects in relation to his/her qualification during the course, if the abilities and acquired skills were found according to his/her wishes, in view of what the ones who intend to follow in the job market. Therefore, it is believed that the human resources graduated there are of interest to the labor market, agribusiness. The methodological course of the research will be based on analyzes of quantitative and qualitative data offered by the Technological Department of the State of São Paulo, by the Technical Schools of Centro Paula Souza, the Etecs, and in interviews with students of the $3^{\text {rd }}$ grade Etim (High School Integrated to Technical) teachers and practical subjects (technicals) and rural producers (local) with the purpose of identifying the current profile of the target public of this institution. It is expected, therefore, to enrich the historiographic chart of professional education in the State of São Paulo, by studying the experiences of EtecAgrícola, both its past structure and its current structure, discussing the students' education based on their market expectations and the possibility of insertion in agribusiness. In order to do so, it will be analyzed, based on the expectations of the student, what he expects in relation to his training during the course, if the skills and acquired skills were in agreement with his wishes, in view of what they intend to follow in the job market. Thus, it is believed that the human resources trained there are of

Keywords: History of Professional Education; Centro Paula Souza; Etec Agrícola;

Student; State of São Paulo; Agribusiness. 


\section{LISTA DE TABELAS}

Tabela 1: Participação dos alunos no SARESP 2016 52

Tabela 2: Avaliação do nível de desenvolvimento e aprendizagem, em Língua Portuguesa. 52

Tabela 3: Avaliação do nível de desenvolvimento e aprendizagem, em Matemática....53 


\section{LISTA DE GRÁFICOS}

Gráfico 1: Comparação do percentual de alunos níveis da escala de proficiência no SARESP, 2014 a 2016, em Língua Portuguesa.

Gráfico 2: Comparação do percentual de alunos níveis da escala de proficiência no SARESP, 2014

Gráfico 3: Comparação do percentual de alunos níveis da escala de proficiência no SARESP, 2014 a 2016, e com a meta esperada no Saresp. .54

Gráfico 4: Comparação do percentual de alunos níveis da escala de proficiência no SARESP, 2014 a 2016, em Matemática. 54

Gráfico 5: Comparação de alunos iniciantes com alunos egressos .75 


\section{LISTA DE SIGLAS}

CEETEPS - Centro de Educação Tecnológica Paula Souza

ETEC - Escola Técnica

ETIM - $\quad$ Ensino Técnico Integrado ao Médio

FATEC - $\quad$ Faculdade Tecnológica

SARESP - $\quad$ Sistema de Avaliação do Rendimento Escolar do Estado de São Paulo SP - $\quad$ São Paulo 


\section{SUMÁRIO}

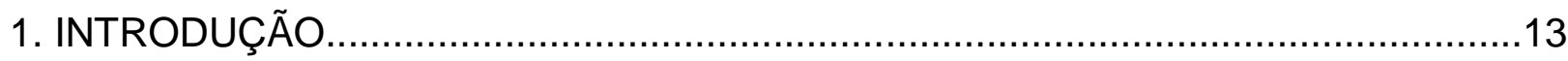

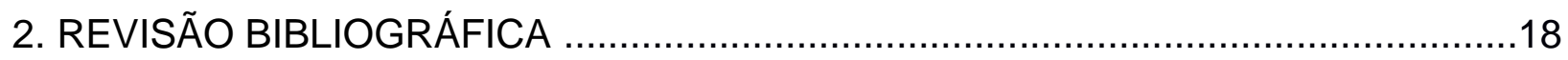

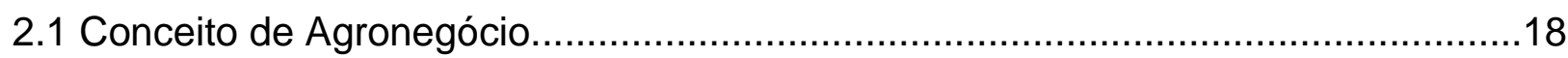

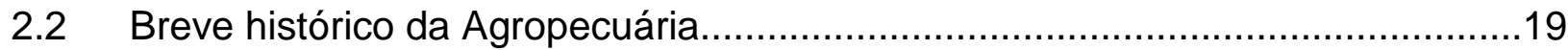

2.3 Histórico da Educação

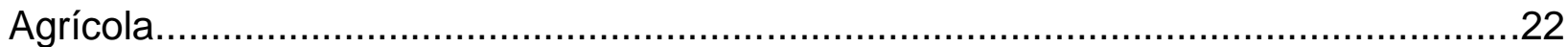

2.4. Breve discussão sobre o papel das Escolas Técnicas Agrícolas do Centro Paula Souza e sua trajetória histórica

31

2.5. Breve Histórico da ETEC Manuel dos Reis Araújo, Santa Rita do Passa Quatro -

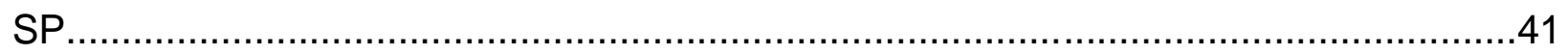

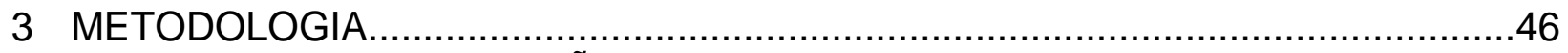

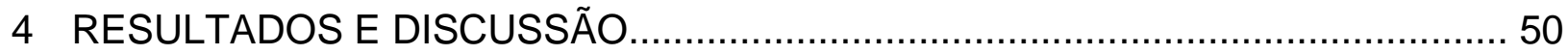

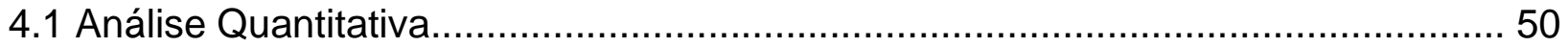

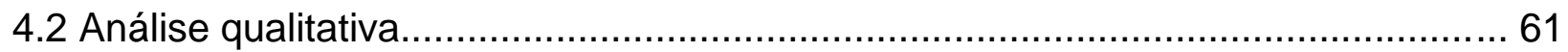

4.2.1 Entrevistas realizadas com alunos do ETIM em Agropecuária........................... 62

4.2.2. Questionário para os alunos da terceira série do ETIM em Agropecuária turma

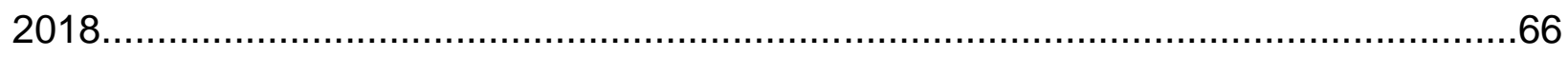

4.2.3 Questionário para os professores de matérias técnicas do ETIM, em

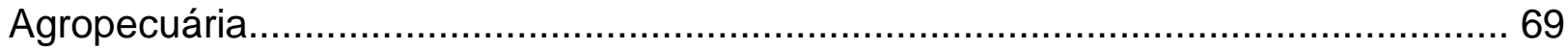

4.2.4 Resultados obtidos através de entrevistas com proprietários de terras.............. 70

4.3 Análise geral dos resultados obtidos..................................................................

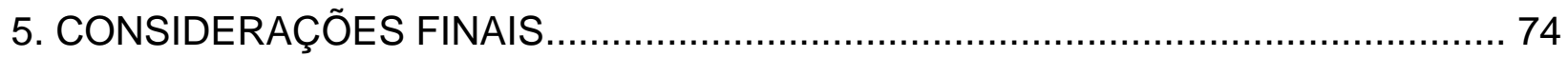

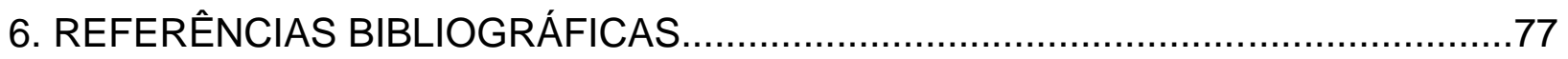

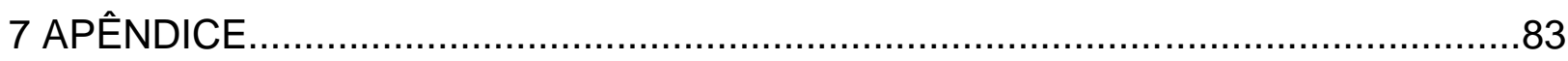

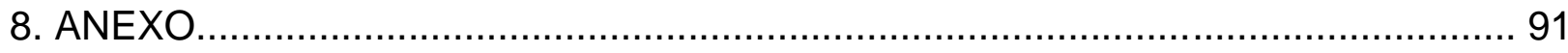




\section{INTRODUÇÃO}

Nas últimas décadas do século XIX e durante o século $X X$ a sociedade brasileira passou por transformações estruturais e fundamentais (CANO, 1977). No âmbito sócio-político identifica-se a mudança do regime de Monarquia para República e a transposição do trabalho escravo para o trabalho livre e, mais especificadamente, do ponto de vista econômico, a reestruturação do sistema produtivo, baseada na mudança da base técnica e na diversificação da produção, após o ciclo do café, com a introdução de maquinários e aperfeiçoamento dos aparatos de comunicação e a criação de instituições, são as transformações mais importantes para a formação do novo quadro sócio econômico brasileiro, que caracteriza os sucessivos modelos de desenvolvimento que o país enfrentou daí em diante (MOLINA, 2010).

Sendo a agropecuária a principal atividade econômica do país e, em se tratando de um momento da história de forte desenvolvimento científico, o mercado mundial, especificamente a partir da Europa e dos Estados Unidos, encontrava-se numa busca intensa de expansão e crescimento. Assim, a demanda, que se acentua no pós Segunda Guerra Mundial, consistia na busca por maior produção de matéria prima e alimentos, aumento do número de consumidores e, por mão de obra especializada que soubesse manejar as novas tecnologias da indústria e do campo.

Essas transformações levaram o Estado e a iniciativa privada a propor algumas ações para a criação de instituições de pesquisa e ensino agrícola, objetivando a otimização da produção no campo, tornando o setor mais racionalizado e produtivo, para que o Brasil pudesse competir a nível internacional e também suprir as necessidades internas:

A sociedade capitalista, em seu processo de desenvolvimento, é marcada, em períodos específicos de sua "evolução", pela ocorrência de mudanças drásticas na forma de organização do trabalho (POCHMANN, 2001) implicando consequências para o conjunto dos trabalhadores. Olhando, especificamente para os agricultores, pode-se observar que, ao longo do tempo, em todos os momentos de transformações, esses sujeitos têm sido alvo de um processo de destruição/construção, que continua desde a Primeira Revolução Industrial até nossos dias. (GRITTI, 2007, p. 01)

Tais ações levaram a adequação da mão de obra brasileira, oferecendo, através da criação de instituições de ensino e de pesquisa, a qualificação necessária, a 
cada época, para o trabalho no campo, já que o Brasil, passa a vivenciar um momento histórico específico, qual seja, o desenvolvimento e crescimento de um modo de produção construído nos termos de relações capitalistas:

Inicialmente, a atividade produtiva decorrente deste modelo produtivo, prescindia de qualificação para o conjunto dos trabalhadores. Portanto, uma educação pública para a população não era tida como necessária. [...]é com o fim da escravidão, com a produção cafeeira e também com o desenvolvimento de outras culturas de importância para a agricultura, que decorre a necessidade de qualificação para o trabalho agrícola. Assim, o "ensino da escola elementar, como a escola técnica de $2^{\circ}$ grau, começou a impor-se como uma forma de suprir as necessidades que se esperava fossem atendidas a partir do ensino escolar" (GRITI, 2007, apud CALAZANS, 1993, p. 15).

Observa-se que, anteriormente ao início da ciência Agronômica moderna ${ }^{1}$, o trabalho no campo se realizava com a combinação de misticismo, empirismo, tradição oral e secular. Alguns estudos apontam evidências de que no Brasil ocorreram fenômenos astronômicos que foram considerados desgraças divinas. A passagem de cometas em 1666 e, um eclipse lunar em 1685, foram vistos como maldição divina, responsáveis pelas pestes em geral e óbitos que acometeram os escravos e trabalhadores livres, mais os desastres das colheitas daqueles anos (DEL PRIORE, 2006).

Desse modo, o desenvolvimento de um modelo educacional encontrou alguns entraves no Brasil. Por conta dos preconceitos com relação aos trabalhos manuais, antes tarefa delegada aos escravos, ou seja, vista como atividades pouco nobres, e

${ }^{1}$ A agricultura moderna tem suas origens ligadas às descobertas do século XIX, a partir de estudos dos cientistas Saussure (1797-1845), Boussingault (1802-1887) e Liebig (18031873). Liebig difundiu a ideia de que o aumento da produção agrícola seria diretamente proporcional à quantidade de substâncias químicas incorporadas ao solo, no entanto, mesmo com sua teoria desmascarada com o surgimento de evidências científicas a respeito dos equívocos de Liebig, a repercussão de suas descobertas havia criado um mercado altamente lucrativo de fertilizantes artificiais. (FRADE, Carmem Oliveira. A construção de um espaço para pensar e praticar a Agroecologia na UFRRJ e seus arredores. Dissertação de Mestrado. Rio de Janeiro: CPDA/UFRRJ, 2000.) 17) [...]. As descobertas de todos esses cientistas marcam o fim de uma longa data, da Antiguidade até o século XIX, na qual o conhecimento agronômico era essencialmente empírico. A nova fase será caracterizada por um período de rápidos progressos científicos e tecnológicos. (EHLERS, Eduardo. Agricultura Sustentável: Origens e perspectivas de um novo paradigma. São Paulo: Livros da Terra, 1996:In :MOLINA, Rodrigo Sarruge, 2010) 
consideradas até mesmo indignas e degradantes, havia a necessidade de se construir, segundo lanni (1977), um sistema forte, competitivo e integrado na nova realidade capitalista em finais do século XIX e início do XX, fortemente gerido pelas elites, com processos de formação de mão-de-obra que já integrassem mudanças sociais e culturais.

A escola aparece, segundo Saviani (1999), apud MOLINA (2010), como uma instituição, inicialmente desenvolvida com o intuito informal e espontâneo e que, em seguida, se constitui como uma estrutura material que é desenvolvida para atender as necessidades sociais de caráter permanente:

O processo de criação de instituições coincide com o processo de institucionalização de atividades que antes eram exercidas de forma não institucionalizada, assimétrica, informal, espontânea. A instituição corresponde, portanto, a uma atividade de tipo secundário, derivada da atividade primária que se exerce de modo difuso e inintencional. (MOLINA, 2010, p. 04)

$E$, mesmo quando pensamos a escola dentro de sua perspectiva pedagógica histórico/crítica, temos que, segundo Saviani (2013, p.85) a "Pedagogia HistóricoCrítica" não é outra coisa senão aquela pedagogia empenhada decididamente em colocar a educação a serviço da referida transformação das relações de produção."

Nesse sentido, deposita-se na proposta de ensino agrícola a personificação de instrumento formador dos indivíduos desejados pela sociedade moderna ${ }^{2}$ que atenda os novos modelos da demanda do consumo.

É frente ao desejo de modernizar a agricultura que, a partir da década de 1910, é proposta uma política pública para o ensino agrícola no Brasil. A partir do projeto proposto pelo Ministério da Agricultura no decreto no 8.319, assistiremos a uma série de intervenções do Estado. Nossa análise de fontes consultadas apontou o agrônomo como individuo que seria responsável por uma inovação no mundo rural, e o ensino agrícola como o instrumento de formação e de legitimação desse agente social. (ARAÚJO, 2013, p. 04)

Um exemplo da primeira tentativa da parceria Estado e iniciativa privada, na região de São Paulo, foi a Escola Agrícola Prática de Piracicaba, posteriormente transformada na Escola Superior de Agricultura Luiz de Queiróz (Esalq/USP).É

2 ARAÚJO, Bruno Melo de. O Ensino Agrícola e a Educação. XXVI Simpósio nacional de História. ANPUH. Conhecimento histórico e dialogo social. Natal, RN, 22 a 26 de julho de 2013. 
importante ressaltar que naquela época a referida escola destacava-se das outras unidades federativas por conta da lavoura cafeeira. Segundo Perecin (2004), o intuito dessa instituição era difundir noções, preceitos e práticas agrícolas, focadas em lições teóricas elementares, subordinadas à Secretaria da Agricultura. Mais tarde, dentro do segmento de educação técnica e tecnológica nascem, na década de 1960, as Escolas Técnicas de Nível Médio-ETECs e as Faculdades de Tecnologia-FATECs, ambas pertencentes ao Centro Paula Souza.

Sabe-se que as ETECs Agrícolas, que ainda eram chamadas de Escolas de Iniciação Agrícola, em geral, começaram a crescer no Brasil a partir da promulgação da primeira Lei de Diretrizes e Bases, que rege a educação nacional, fato que ocorreu na década de 1960. Estas escolas foram denominadas "Escolas Agrícolas" e, somente na década de 1990 passaram para Secretaria Tecnológica. É importante ressaltar que as Escolas Agrícolas, que antes ficavam a cargo da Secretaria da Educação, passaram a se chamar ETE e, após os anos 2000, com projeto de expansão do governo Estadual para o Centro Paula Souza, ETEC.

Para completar a formação de quadros especializados, cada ETEC, em vista das necessidades das regiões, nas quais estão instaladas, implantaram novos cursos técnicos, além dos agrícolas. No caso de Santa Rita do Passa Quatro, São Paulo, existem os cursos técnicos de Açúcar e Álcool, Química, Enfermagem, Recursos Humanos e Informática. Atualmente o Centro Paula Souza conta com 35 das chamadas "ETECs Agrícolas" espalhadas pelo Estado de São Paulo.

Ao observar-se na presente pesquisa as experiências vividas pela escola agrícola, do Centro Paula Souza, a ETEC Manoel dos Reis Araújo, Santa Rita do Passa Quatro, Estado de São Paulo e suas contribuições para com o fornecimento de mão de obra especializada, utilizando-se da verificação do perfil atual do estudante dessa instituição, acredita-se na hipótese de que os recursos humanos formados, nessa instituição de ensino, interessam ao mercado de trabalho afim, ou seja, ao agronegócio.

Nesse sentido, o objetivo específico consiste em analisar as expectativas dos estudantes em relação à sua formação ao longo do curso, se as competências e habilidades adquiridas foram de encontro aos seus anseios, tendo em vista o que pretendem seguir no mercado de trabalho. Como objetivo geral busca-se: abordar um breve histórico a respeito da agricultura brasileira; descrever o histórico da educação profissional agrícola; apresentar um breve histórico da ETEC Manuel dos Reis Araújo, Santa Rita do Passa Quatro - SP, tendo em vista sua missão, visão e objetivos 
estratégicos, cuja finalidade é a construção contínua da formação crítica e profissional do estudante.

O percurso metodológico da pesquisa será pautado em análises de dados quantitativos e qualitativos oferecidos pela Secretaria Tecnológica do Estado de São Paulo, pelas Escolas Técnicas do Centro Paula Souza, as ETECs, e em entrevistas com estudantes do $3^{\circ}$ ano, do Ensino Médio Integrado ao Técnico-ETIM, professores e matérias práticas (técnicas) e produtores rurais (locais), com finalidade de identificar o atual perfil do público alvo dessa instituição.

Espera-se, através dessa pesquisa, enriquecer o quadro historiográfico da educação profissionalizante do Estado de São Paulo, elaborando um estudo das experiências da ETEC Agrícola, tanto da sua estrutura passada quanto da atual, discutindo a formação dos alunos a partir de suas expectativas de mercado e a possibilidade de inserção no agronegócio.

Para efetuar as intenções apresentadas, a dissertação foi dividida em: Resumo: 1- Introdução; 2 -Revisão Bibliográfica; 3 - Metodologia: - 3.1. - Análise quantitativas e 3.2.- Analise qualitativas; 4 - Resultados e Discussões; 5- Conclusões; 6 - Referências bibliográficas; 7 -Apêndices; 8- Anexos. 


\section{REVISÃO BIBLIOGRÁFICA}

Esse capítulo apresenta um embasamento teórico, focalizando o tema em questão, analisando os vários elementos que o compõe, através da busca de diálogo com autores que sustentam a análise aqui pretendida. O seu conteúdo aborda 0 conceito de agricultura e agronegócio, histórico da Educação Profissional, a implantação do Centro Paula Souza e a fundação da Etec Manuel dos Reis Araújo. Em seguida, destaca a importância do Plano de Curso que ampara o Ensino Médio Integrado ao Técnico em Agropecuária.

\subsection{Conceito de Agronegócio}

Dentro do tema proposto para estudo, sobretudo no que diz respeito ao título do trabalho, coloca-se o segmento do agronegócio como primeira opção de inserção do estudante do curso técnico em Agropecuária. Segundo o Plano de Curso (2016, p. 138):

[...] é essa peculiaridade que produz o grande desafio do ensino agropecuário, por um lado comprometido com o desenvolvimento social do jovem e da atividade rural, e por outro, promotor do desenvolvimento do agronegócio, oferecendo oportunidades e capacitando o jovem de qualquer origem, interessado na atividade agrícola de forma mais abrangente e que extrapola a propriedade rural.

Tendo em vista o agronegócio como parte integrante de seu interesse no processo ensino/aprendizagem do curso, é importante descrever seu significado, sua abrangência de mercado e a demanda de qualificação de trabalho necessária para atender suas finalidades.

Nesse sentido, segundo Toresan (2006) e Zylbersztajn (2000), a primeira definição de agronegócio partiu de dois professores de Harvard, que foram os pais do conceito (agribusiness): John H. Davis e Ray Goldberg ${ }^{3}$. Usando as técnicas matriciais de insumo-produto, observaram que havia um novo sistema diferente do antigo, em

3 Agribusiness coordination: a systems approach to the wheat, soybean and Florida orange economies. Division of research. Graduate School of Business Administration. Boston: Harvard University, 1957 ( In: Silva, da Nivaldo Pereira) 
gênero e espécie. Esse novo sistema, denominado agribusiness, seria o conjunto das operações de produção e distribuição de insumos e novas tecnologias agrícolas, da produção, do armazenamento, do transporte, do processamento e distribuição dos produtos agrícolas e seus derivados. (SILVA, 2011)

O conceito sobre agronegócio, na visão de Sobral (2009), ganhou proporção a partir dos anos de 1980, período conhecido como globalização da economia. Assim, com a intensificação da aplicação da tecnologia, visando uma nova configuração do processo produtivo, a palavra agronegócio ganha um novo sentido, levando em consideração a construção da imagem da agricultura, com propriedades mais modernas, agregando informações aos produtos e processos de produção de insumos ${ }^{4}$, implementos, equipamentos e a cadeia em si.

Nesse sentido, é importante destacar que, para alavancar a produção agrícola, o sistema incorporou variadas tecnologias, destinadas às atividades rurais. Essas inovações interferem diretamente na cadeia produtiva, coordenando as formas de produção, devido às necessidades dos grandes produtores e exportadores de aplicar os avanços tecnológicos no agronegócio.

Pode-se caracterizar o termo como referente ao que consiste em negócios no setor da agropecuária. Assim, compreende tudo o que envolve desde a fabricação dos insumos essenciais, a produção agropecuária propriamente dita e, os procedimentos que envolvem a produção até atingir o consumidor final. $O$ agronegócio é o desdobramento do processo que tem como fonte de sustentação a agropecuária. 0 processo agrícola passa por alterações constantes, desde que o homem passou a explorar os recursos naturais para sua sobrevivência, é possível identificar profundas alterações no processo agrícola. O conteúdo a seguir descreve um breve histórico da atividade agrícola.

\subsection{Breve histórico da Agropecuária}

A história da agricultura se confunde com a história da humanidade, no sentido último de constituir o processo produtivo fundamental que permitiu ao ser humano organizar suas diferentes sociedades nas mais diversas condições. Quando se aborda esse assunto, logo tem-se em mente o processo histórico ligado a essa prática, que vai

$4 \quad$ Esses "insumos modernos" são entendidos como máquinas, tratores colheitadeiras, fertilizantes, defensivos químicos etc. 
desde seu surgimento, relacionado com o processo pelo qual o homem deixou de caçar e coletar alimentos na natureza, para cultivar a terra e criar animais, até os dias atuais com toda sua tecnologia e formas de produção.

Essa primeira fase é conhecida como "revolução agrícola neolítica" e teria ocorrido há cerca de dez a doze mil anos. Provocou impactantes mudanças na relação homem/natureza, permitindo quando e como pudesse controlar o cultivo e a domesticação de plantas e animais (SANTILLI, 2009, p.35).

Em seu livro "Agrobiodiversidades e Direito dos Agricultores", Santilli(2009, p. 36) defende:

Essa mudança na relação do homem com a natureza foi lenta e gradual, e pode-se dizer, usando as palavras de Harlan, que "a agricultura não foi descoberta ou inventada" longo de séculos e passou por transformações sucessivas, que afetaram as sociedades humanas em tempos e lugares distintos. $\mathrm{O}$ desenvolvimento dos sistemas agrícolas esteve associado a mudanças ambientais, sociais, econômicas e culturais.

[...] a agricultura contribuiu, entretanto, para um aumento de dez vezes da população humana (que passou de 5 para 50 milhões de pessoas no período de dez mil a cinco mil anos atrás), já que permitia alimentar um número maior de pessoas do que a caça e a coleta. (...) Ela teria sido ainda facilitada por um novo processo de fabricação de instrumentos: polimento de pedra, (...).

Assim sendo, é possível observar a importância da agricultura para o processo de crescimento e desenvolvimento da sociedade humana e quanto foi útil a invenção e sofisticação de técnicas e tecnologias de manejo com a terra para a sobrevivência dos seres humanos. Na citação anterior, fica claro que, historicamente, o aprimoramento dessas práticas auxiliaram, tanto para suportar o aumento populacional, quanto para garantir a qualidade de vida das pessoas.

Em um salto histórico, mais especificamente nos finais de século XIX e início do século $\mathrm{XX}$, com o desenvolvimento do pensamento científico, principalmente por conta das políticas de incentivo à industrialização e ao aumento da produção no campo, marcadas na segunda fase da Revolução Industrial ocorre uma grande mudança no processo de formação e de especialização do trabalho. Como observa Molina(2010, p. 16), em seu artigo sobre História da Educação Agrícola:

$5 \quad$ Jack R. Harlan. The living fields: our agricultural heritage. Cambridge: Cambridge University Press, 1995, p.239. In: SANTILLI, 2009, p. 36. 
(...) o século XIX e as primeiras décadas do XX, o contexto econômico era de forte concorrência no mercado mundial de produtos agropecuários, reflexo direto do novo imperialismo desencadeado pelas nações industrializadas da Europa que começaram a produzir matéria prima e alimentos em suas colônias em todo globo terrestre. Assim, parte dos ruralistas nacionais de tendência ilustrada empresarial entenderam a importância de inovar o sistema produtivo com máquinas, comunicação (estradas, portos, trem) e a introdução de instituições de pesquisa agrícola (...).

Foi no século $X X$ que ocorreram as mais acentuadas mudanças, principalmente no que se refere aos efeitos tecnológicos. Esse período ficou conhecido como a era das grandes revoluções que transformaram, sem precedentes, o modo de vida das sociedades em geral. Nesse sentido, Sacilotto (2016, p. 57) destaca:

[...] As demandas de consumo mais diversificados, o período da guerra e pós, a necessidade de provera produção local para substituir as importações, o nacionalismo crescente que também contamina a área educacional produz nova institucionalidade para educação profissional, delimitada pela complexidade crescentes dos processos produtivos, pela ampliação das ocupações no âmbito da divisão técnica do trabalho, pelo surgimento de novas especialidade.

No final da Segunda Guerra Mundial, 1939 - 1945, essa transformação ficou bastante evidenciada devido às disputas dos países vencedores que procuraram manter a hegemonia do mundo dividindo-o em dois blocos, socialista (URSS) e capitalista (EUA). O ponto de partida seria a reconstrução dos países arrasados pelo conflito, financiados por planos econômicos organizados pelas grandes potências em questão, tais como os Plano Marshall ${ }^{6}$ (EUA)e Comecon $^{7}$ (URSS).

$6 \quad$ Com base na Doutrina Truman, no ano de 1948 foi instaurado o Plano Marshall, o nome faz referência a seu inventor o então secretário do Estado Americano George Marshall, que visava à reconstrução da Europa. Inicialmente o Plano Marshall iria beneficiar alguns países de influência soviética, disponibilizando bilhões de dólares com intenção de seduzir essas nações da Europa central a ficar do lado dos EUA (capitalismo). Isso deixou a URSS preocupada, temendo que seus países satélites viessem a ficar do lado norte-americano colocando em risco a segurança nacional. Como esses países não aceitaram os recursos, ficaram de fora do plano. Disponível em: https://mundoeducacao.bol.uol.com.br/geografia/plano-marshall.htm. Consultado em: 10/08/2018.

7 COMECON é a sigla correspondente a Conselho para Assistência Econômica Mútua, uma organização internacional fundada em 1949. O COMECON visava à integração econômica das nações do Leste Europeu e o impedimento do avanço do Plano Marshall sobre a região. 
O intuito era buscar cada vez mais aliados para suas respectivas ideologias político-econômicas. Nesse sentido, maciços investimentos foram aportados nas inovações tecnológicas de máquinas, equipamentos e, principalmente, no que tange à cadeia do sistema produtivo de linha primária, ou seja, agrícola. Assim sendo, o investimento na agricultura visava abastecer a demanda do crescente mercado que necessitava de novas opções de consumo, uma vez que a Europa se encontrava em escassez de vários produtos do gênero, pois os campos foram totalmente destruídos pela Segunda Guerra Mundial.

Percebe-se, com isso, que para atender a estrutura social e econômica dessa realidade da segunda metade do século $X X$, tem-se o nascimento de uma nova dinâmica de organização do conjunto de operações embutidos dentro das perspectivas da cadeia produtiva agrícola e pecuária, a qual denomina-se como agronegócio.

O conteúdo a seguir apresenta breves embasamentos históricos sobre o surgimento da Educação Profissional Agrícola no Brasil e, o quanto está diretamente vinculada às necessidades da agricultura e seus desdobramentos.

\subsection{Histórico da Educação Profissional Agrícola}

A formação e o treinamento são importantes ferramentas para a capacitação do profissional rural. Assim, busca-se as informações necessárias para equacionar a produção do agronegócio. Tomando o conhecimento como o grande desafio das organizações atualmente, busca-se transformar o agronegócio sustentável em melhoria na condição de vida do ser humano, com menor degradação do meio ambiente, gerando a capacidade de diferenciação dos produtos dentro do mercado e, abrindo novas oportunidades para agricultores e produtores.

O Brasil, em grande medida, é um país cuja economia depende dos produtos agrícolas. Historicamente, se explica pelo contexto do processo de colonização, período no qual a exploração ocorreu, principalmente, tendo como foco as riquezas proporcionadas pela natureza.

Gasqueset al. (2004) ressaltam que o agronegócio representa um segmento de grande importância para a economia brasileira, que contribui para estabilizar a

Disponível em: https://www.estudopratico.com.br/comecon-integracao-das-nacoes-do-lesteeuropeu/. Consultado em 10/08/2018. 
macroeconomia, gerando empregos e renda, possibilitando equilibrar o déficit comercial provindo de outros setores produtivos.

Assim sendo, houve por parte da iniciativa pública e privada preocupações com o desenvolvimento de práticas embutida de ações mais produtivas para atingir resultados crescentemente expressivos na cadeia produtiva.

Dessa maneira, apesar do desenvolvimento de atividades econômicas de diversas naturezas, se observa que apesar do avanço social e econômico proposto pela nova ordem mundial, dentro do que convencionou-se chamar de "Globalização", o Brasil ainda mantém no agronegócio a base de sua ordenação e projeção econômica. Segundo informações obtidas pelo jornal "O Estado de São Paulo”, de março de 2010, seu projeto histórico inicial de política comercial, de agroexportador, o posiciona como o terceiro país do mundo em exportações de gêneros agrícola:

O Brasil ultrapassou o Canadá e se tornou o terceiro maior exportador de produtos agrícolas do mundo. Na última década, o País já havia deixado para trás Austrália e China. Hoje, apenas Estados Unidos e União Europeia vendem mais alimentos no planeta que os agricultores e pecuaristas brasileiros.

Dados da Organização Mundial de Comércio (OMC), divulgados este ano, apontam que o Brasil exportou US\$ 61,4 bilhões em produtos agropecuários em 2008, comparado com US\$ 54 bilhões do Canadá. Em 2007, os canadenses mantinham estreita vantagem, com vendas de US $\$ 48,7$ bilhões, ante US\$ 48,3 bilhões do Brasil.

[...] O ritmo de crescimento da produção brasileira de alimentos já deixava claro que a virada estava prestes a ocorrer. Entre 2000 e 2008, as exportações agrícolas do Brasil cresceram 18,6\%, em média, por ano, acima dos 6,3\% do Canadá, 6\% da Austrália, 8,4\% dos Estados Unidos e 11,4\% da União Europeia. Em 2000, o País ocupava o sexto lugar no ranking dos exportadores agrícolas. ${ }^{8}$

O cenário de exportação de produtos agrícolas atualmente encontra-se responsável por $70 \%$ do total de produtos enviados para o exterior. No entanto, no Brasil a atividade representa $8 \%$ do PIB (Produto Interno Bruto) brasileiro e gera emprego para pelo menos $10 \%$ da população economicamente ativa do país. (Plano de Curso, 2016, p 05)

A atividade do setor agrícola é uma das mais importantes da economia brasileira, pois, embora componha pouco mais de $5 \%$ do PIB brasileiro

8 Disponível em: https://economia.estadao.com.br/noticias/geral,brasil-ja-e-o-terceiro-maiorexportador-agricola-do-mundo,520500. Consultado em 31/08/2018 
na atualidade, é responsável por quase $\mathrm{R} \$ 100$ bilhões em volume de exportações em conjunto com a pecuária, segundo dados da Secretaria de Relações Internacionais do Ministério da Agricultura, Pecuária e Abastecimento (SRI/Mapa). A produção agrícola no Brasil, portanto, é uma das principais responsáveis pelos valores da balança comercial do país. $^{9}$

Porém, essa discussão tem âmbitos muito mais profícuos do que se atreveu a presente pesquisa, principalmente quando se observa estudos de autores, sejam economistas, historiadores, jornalista e sociólogos, que tratam com propriedade o assunto, tais como Albuquerque (1977, p 05):

Com efeito, é possível observar o modo pelo qual o crescimento é gerado, comparando fatos empíricos com os modelos teóricos que neles se originam; este método, no entanto, implica um raciocínio circular. Conquanto as teorias ortodoxas do crescimento possam ser muito uteis na formulação de política - no sentido de que apresentam um alvo a ser atingido - pouco ajudam no estabelecimento de relacionamentos casuais e na explicação de tendências históricas.

Ainda nesse contexto, Albuquerque (1977, p. 06), inspirado por Caio Prado, cita um trecho de História Econômica do Brasil:

O simples fato da inversão, como pretende a teoria ortodoxa, ou mesmo o fato mais geral e amplo da origem e formação do capital e de sua acumulação, pouco ou nada explica dos fatos originários que impulsionam o crescimento. O que deve ser considerado e dá conta desse crescimento é o que está por trás e na base das inversões.

O não historicismo e a subestimação da especificidade histórica dos países subdesenvolvidos tornam a teoria ortodoxa incapaz de avaliar as circunstâncias peculiares em cada lugar ou categoria sócio econômica, condicionam as inversões e dão a medida de sua fecundidade e capacidade de determinar um processo auto estimulante de crescimento que é o que se procura realizar.

Devido às mudanças na demanda de consumo, denominadas por Prado(1969), apud Albulquerque(1977), de processo auto estimulante de crescimento, houve uma preocupação com relação à melhoria dos procedimentos educacionais para obtenção de maior produção em todos os âmbitos, seja na indústria ou no campo ( FRIGOTTO, 2006).

Segundo Silva (2007, p.02):

9 Disponível em: $\underline{\text { https://mundoeducacao.bol.uol.com.br/geografia/agricultura-no-brasil- }}$ atual.htm. Consultado em 31/08/2018 
Sendo o Brasil um país extremamente agrícola, deve incorporar as inovações tecnológicas nas atividades voltadas para o campo. 0 sucesso neste processo de modernização deve-se aos investimentos públicos e privados, efetuados na melhoria contínua dos equipamentos e máquinas, e na especialização dos recursos humanos, principalmente no treinamento dos técnicos na área agrícola.

Voltados para a preocupação de desenvolvimento e aumento da produção agrícola que, em consequência, alimenta diretamente o agronegócio, a principal fonte de arrecadação brasileira, o caminho mais eficaz é o investimento na área. Esses investimentos vão desde os implementos, equipamentos, ou seja, tudo que alimenta e proporciona a cadeia produtiva agrícola, até a parceira do setor privado e público na busca pelo aperfeiçoamento de mão de obra qualificada. Nesse sentido, descreve Sobral (2009, p. 81 e 82):

A prosperidade econômica no Brasil, no final do século XIX e início do século $X X$, se orientava através da atividade agroexportadora - cultura do café. No entanto, já existiam no país, incentivos para o desenvolvimento da indústria. A preparação de mão-de-obra para as indústrias estava a cargo de poucas instituições. "A partir de 1906, a Câmara dos Deputados, através da proposição 195, habilitou o Estado a destinar recursos financeiros para a criação de escolas profissionais federais". Afonso Pena, na época Presidente da República, de certo modo, norteou o desenvolvimento das escolas profissionais ao considerar que: "a criação e multiplicação de institutos de ensino técnico e profissional, muito podem contribuir também para o progresso das indústrias, proporcionando-lhes mestres e operários instruídos e hábeis".

Nesse período ocorre a criação de escolas voltadas ao ensino de habilidades profissionais, consideradas de ensino técnico a partir de 1909, pois nesse ano, no dia 23 de setembro, o Decreto no 7.566 de Nilo Peçanha (Presidente da República por morte de Afonso Pena), institui a Rede Federal de Escolas Industriais. As chamadas "Escolas de Aprendizes e Artífices" (uma em cada estado da União) tinham por finalidade formar contra-mestres e operários. "Essas escolas possuíam orientação didática própria e subordinavam-se diretamente às Diretorias Gerais da Indústria e Comércio e de Contabilidade, do Ministério da Agricultura".

Essa foi uma primeira tentativa ousada do Estado de implantar um sistema educacional voltado para qualificação da formação no setor. Tendo em vista que os recursos eram bastante precários, devido ao grande volume da população miserável e uma filosofia educacional, que adotava prerrogativas de relevância discriminatória e reducionista, os interesses eram simplesmente atender a demanda da economia cafeeira. Nesse contexto, Sobral (2009, p 83) percebe: 
[...] Com efeito, o período republicano referendou a concepção de um ensino profissional com características exclusivas de ensino voltado para os menos favorecidos. A pressão da agricultura na economia brasileira gerou o Decreto no 8.319, de 20 de novembro de 1910, que trouxe a primeira regulamentação e estruturação do ensino agrícola no Brasil, passando a ser ministrado em quatro categorias, a saber: Ensino Agrícola Superior, Ensino Agrícola Médio, Aprendizes Agrícolas e Ensino Primário Agrícola. Esse Decreto apresenta como finalidade precípua "a instrução técnica profissional relativa à agricultura e às indústrias correlatas, compreendendo: Ensino Agrícola, Ensino de Zootecnia, Ensino de Indústrias Rurais e Ensino de Medicina Veterinária".

A ideia do progresso, presente na primeira república, como fator decisivo na superação do atraso em que se encontrava o país, quando comparado com países europeus, vai fazer da técnica e do seu domínio o caminho para o desenvolvimento.

Tais acontecimentos apresentam reflexos na educação, pois debates entre educadores de diferentes correntes de pensamento começam a acontecer, potencializando a discussão sobre o tema no Brasil. Incluemse aqui as ideias do grupo de pioneiros do "ruralismo pedagógico", que, percebendo estarem as políticas educacionais centralizadas no meio urbano, em função da crescente urbanização pela industrialização emergente, acabavam por marginalizar a educação no meio rural. Importa lembrar que o crescimento das cidades e a incapacidade de absorção de toda mão-de-obra disponível pelo mercado de trabalho urbano faziam com que o problema migratório fosse visto pelos grupos dominantes como uma permanente ameaça. Políticos e educadores manifestavam-se no mesmo sentido: era preciso conter a migração, e um dos instrumentos para fixar o homem no campo era a educação. $E$ dentro desse contexto inicia-se aí o "ruralismo pedagógico", como tentativa de fazer o homem do campo compreender o "sentido rural da civilização brasileira" e de reforçar os seus valores a fim de prendê-lo à terra, para tanto era preciso adaptar os programas e currículos ao meio físico e à "cultura rural".

Por essa via de fatos, observa-se o compromisso, que ao longo de vários anos,foi sendo selado através da criação de diferentes medidas legislativa. Essas medidas pretendiam dar ênfase à qualificação profissional, voltada para o atendimento das necessidades da economia do setor primário e, também, absorver o contingente de trabalhadores vindos da imigração e da migração.

No caso dos investimentos públicos na área da educação profissional agrícola, especificamente no Estado de São Paulo, houve a preocupação em manter e dar subsídios para um sistema de ensino específico, as ETECs, ou antigas Escolas Agrícolas. Desse modo, decide-se pela manutenção de 35 escolas agrícolas espalhadas no interior do estado de São Paulo, que oferecem e se preocupam com esse tipo de qualificação, conforme será abordado em um subitem dessa pesquisa.

Porém, no Brasil a educação profissional agrícola, como já mencionado, antes de consolidar-se como processo efetivo de formação ensino/aprendizagem, enfrentou 
muitos preconceitos e preceitos, mesmo porque, a concepção de trabalho e qualificação para seu ofício como projeto de vida é uma ideia bastante recente.

Quando buscamos olhar para a dimensão histórica que dá origem ao processo de formação de mão-de-obra no Brasil, temos que, considerando desde os primeiros trabalhos dos jesuítas, até os anos 30 , do século XX, prevaleceu a ideia do trabalho enquanto dimensão inferior da vida humana, havendo um dualismo concebido como natural e necessário entre o trabalho manual e intelectual. Destinado, quase como castigo, aos setores marginalizados da sociedade, a ideia de formação para o trabalho (KUNZE, 2009). Contudo, vale lembrar, que o ensino agrícola veio a configurar-se como uma solução para o clima de instabilidade gerado no campo pelos movimentos da abolição e Proclamação da República. (ARAÚJO, 2013)

Sacilotto(2016, p 53), confirma a prerrogativa histórica:

Considerando que o aumento constante da população das cidades exige que se facilite às classes proletárias os meios de vencer as dificuldades sempre crescentes da luta pela existência; para isso se torna necessário, não só habilitar os filhos dos desfavorecidos da fortuna com o indispensável preparo técnico e intelectual, como fazê-los adquirir hábitos de trabalho profícuo, que os afastará da ociosidade ignorante, escola do vício e do crime; que é um dos primeiros deveres do Governo da República formar cidadãos uteis à Nação.

O processo que construiu a política educacional baseada em diretrizes que vão assumir de forma bem definida a capacitação para o trabalho está no período varguista (MENDONÇA, 2006). Esse período é considerado o grande marco estrutural da educação, pois apresenta uma marcha modernizadora dos aparelhos estatais de administração voltada para a formação do trabalhador.

Nesse contexto, o Governo Provisório criou o Ministério da Educação e Saúde Pública, (14/111930), tendo como seu primeiro titular Francisco de Campos, que, a partir de 1931, elaborou e implementou reformas no ensino secundário e superior. (ARAÚJO, 2013). Segundo Sobral (2009, p. 82):

A constituição de 1934 determinou que cabia à União a responsabilidade em traçar diretrizes educacionais para todo território nacional. Neste período, testemunhou-se uma expansão no meio industrial no Brasil. O ensino técnico industrial começou a fazer parte dos debates nacionais como elemento importante na defesa da indústria brasileira, que começava a se consolidar e, consequentemente, na formalização das relações de trabalho e das atividades sindicais.

Nessa lógica, foi criado o modelo de ensino técnico que marcou a fundação das primeiras Escolas Técnicas, perpassando décadas. Mas, somente após o fim da ditadura de Vargas foi que o ensino agrícola de 
nível médio teve sua primeira regulamentação estabelecida pelo Decreto-Lei $n^{\circ}$ 9.613, de 20 de agosto de 1946, denominado de "Lei Orgânica do Ensino Agrícola":

"Art. $1^{\circ}$. Esta lei estabelece as bases de organização e de regime do ensino agrícola, que é o ramo de ensino até o segundo grau, destinado essencialmente à preparação profissional dos trabalhadores da agricultura".

O que se percebe é que, após o governo de Getúlio Vargas, houve um progresso na construção dos currículos escolares com a criação de uma instituição especializada em organizar e planejar estratégias para o desenvolvimento das competências que norteiam as relações de trabalho no campo. A criação da primeira LDB ${ }^{10}$, Lei de Diretrizes e Bases em $1961^{11}$, teve a preocupação de padronizar e qualificar a grade curricular das escolas brasileiras, como escreve Sobral (2009, p. 84):

A partir de 1964, auge da modernização do país e da ênfase em sua participação na economia internacional, quando se discutiam as questões que embasaram o desenvolvimentismo, tanto o poder público como o setor privado, assumem a função de preparar recursos humanos para serem absorvidos pelo mercado de trabalho. De início, quem teve mais acesso aos postos de trabalho ainda foi o formado de nível superior, entretanto, a situação de dificuldades instalada nas universidades que não conseguiam absorver a demanda, além dos interesses mais imediatistas do mercado, provocaram o privilegiamento de uma educação profissional de nível médio.

Assim, o ensino técnico assume uma maior importância no sentido de contribuir com as funções político-ideológicas do país, em termos da política de modernização. Com efeito, foi a partir desse momento que o ensino agrícola, em especial o técnico profissionalizante, passa a se expandir pelo país.

Entre o final da década de 1960 e início da década de 1970, o Brasil passou por amplo processo de mudança nos padrões vigentes na produção, que tinha como principal característica a fabricação em

10 Lei de Diretrizes e Bases da Educação Brasileira (LDB) é a legislação que regulamenta o sistema educacional (público ou privado) do Brasil (da educação básica ao ensino superior). Responsável por regulamentar a estrutura e o funcionamento do sistema de educação do país, a lei definiu os objetivos a serem atingidos e reforçou o caráter federativo da educação brasileira.

In:http://portal.mec.gov.br/index.php?option=com docman\&view=download\&alias=6695-dcnparaeducacao-profissional-debate\&ltemid=30192. Consultado em 15/06/2017.

11 (...) Todavia, somente a Lei de Diretrizes e Bases n 4.024 de 20 de dezembro de 1961, manifesta articulação sem restrições entre o ensino secundário e profissional, abolindo, dessa forma, a discriminação contra o ensino profissional por meio da equivalência plena, colocandose, formalmente, um fim na dualidade do Ensino. (...) ( CANALI, 2009, p. 11) 
massa de bens e serviços nos setores econômicos clássicos, ou seja, na agricultura, na indústria e nos serviços.

Nesse contexto, com o advento da Reforma Administrativa dos Ministérios, ocorrida em 1967 e legitimada pelo Decreto Lei oㅡ 200/67, promoveu-se a absorção do Ensino Agrícola pelo Ministério da Educação e Cultura. Em consequência, o órgão responsável, a Superintendência do Ensino Agrícola e Veterinário também foi transferida ao MEC, através do Decreto no 60.731de 19 de maio de 1967, sob a denominação de Diretoria de Ensino Agrícola - DEA, inserindo-se no Departamento de Ensino Médio - DEM, daquele ministério, que absorveu as Diretorias do Ensino Agrícola, Industrial, Comercial e Secundário.

O ensino agrícola passou por inúmeras mudanças até a década de 1970. A“ descontinuidade administrativa", conforme analisa Maduro (1979), acarretada pelas mudanças na administração federal, representou um aspecto negativo para o ensino agrícola, que já não contava com o mesmo respaldo administrativo e financeiro correspondente aos setores de ensino industrial e comercial. Vale lembrar que o desenvolvimento do ensino industrial e comercial processou-se isento da descontinuidade administrativa que caracterizou a administração do ensino agrícola, no entanto o objetivo da formação técnica, independente da área, indicava claramente a formação de mãode-obra para o mercado de trabalho. Prevalecendo esta proposta até 1971, quando da aprovação da Lei no 5.692/71, através da qual tentouse implantar uma escola única em termos de uma educação profissionalizante para todos. Importa lembrar que nesse período histórico, as Escolas Técnicas Federais aumentam expressivamente o número de matrículas e implantam novos cursos técnicos.

Assim, na década de 1980, devido ao processo de mudanças no cenário da cadeia produtiva, impulsionado pela robotização e o alto índice inflacionário causado por planos econômicos fracassados, o Brasil se mobilizou a dirigir e alinhar suas perspectivas estruturais para novas transformações inteiramente condicionadas às exigências dos órgãos financeiros mundiais.

Nesse contexto, na última década de 1990, para atender as demandas da nova ordem mundial, o ensino técnico em Agropecuária passou a ser subordinado à Secretaria Nacional Tecnológica, que por sua vez, estabeleceu as políticas pedagógicas de diretrizes, bases e planos de curso. Segundo Sobral (2009, p. 91):

Nesse período, diferentes projetos de reestruturação do ensino médio e profissional que representavam aspirações de diferentes grupos sociais, foram debatidos antes da aprovação da lei de Diretrizes e Bases da Educação Nacional.

Além dessas discussões, que visam atender as aspirações do mercado em escala mundial, em 1996, foi aprovada a atual Lei de Diretrizes e Bases da Educação 
(Lei 9.394/96) e o Decreto Federal $n^{0}$ 2.208/97 que instituiu as diretrizes para reestruturação do ensino profissionalizante. Na visão de Sobral (2009, p. 91 e 92):

Essa Reforma é implantada dentro do ideário de Estado Mínimo, com fortes reflexos nas escolas federais de educação profissional do país, que vinham debatendo e articulando outro projeto de formação profissional orientado por uma formação profissional politécnica.

[...] A proposta da reforma visava atender à necessidade do grande capital, tanto urbano como agroindustrial em sua reestruturação. A tecnologia de ponta (entendida como dominante), requerida nesse processo demandava também a formação de profissionais polivalentes.

Dentro da expectativa de transformações e adaptações do mercado nacional, houve um grande avanço na produção da agroindústria, porém acompanhado pela drástica diminuição do número de produtores rurais em cidades nas quais os recursos existentes provêm unicamente da cadeia produtiva. O que fez com que o governo federal criasse novas medidas para educação profissional em 2003, a fim de auxiliar os problemas causados pela deficiência de profissionais, capazes de conduzir os setores mais frágeis, do agronegócio no interior do Brasil. Ainda em Sobral (2009, p. 92):

No ano de 2003, com o governo federal, são editadas novas medidas para educação profissional. Ocorre a substituição do Decreto n 2.208/97 pelo Decreto 5.154/04 que elimina determinadas amarras estabelecidas por aquele. A discussão de se construir um projeto politécnico de formação profissional é retomada. A formação profissional orientada exclusivamente para o mercado de trabalho é revista e o conceito de qualidade social passa a fazer parte dos novos projetos de curso.

Mesmo com tantas adequações realizadas pelos governos federais anteriores à educação, elas nunca serão suficientes, pois o mercado estará sempre em constante mutação, ansiando por inovações. Para tanto, faz-se necessária à recorrência da construção e implantação de novos paradigmas educacionais.

Nesse sentido, nas perspectivas educacionais brasileiras do século $\mathrm{XXI}$, novos parâmetros e diretrizes têm sido construídos, discutidos e tão logo serão inseridos na rotina das escolas, sejam públicas ou particulares.

Recentemente o Governo Federal tem trabalhado, visando mudanças na composição das disciplinas que formarão os estudantes para o futuro, ou seja, mercado de trabalho. Nesse sentido, abordam a inclusão no currículo escolar de disciplinas voltadas para a formação técnica no Ensino Médio.

O mais importante aqui é destacar que ao longo da história da educação brasileira a formação profissional passou por várias mudanças, principalmente no 
decorrer do século $X X$, desde o processo de criação de instituições especializadas até o aprimoramento da aquisição cognitiva de competências e habilidades do estudante. Segundo Nagamini (2004, p. 188), apud Molina (2010), essas mudanças vieram para atender os anseios da classe dirigente pautada na revolução técnico-científica, que não mediu esforços para ampliar sua infraestrutura no sentido de enfrentar os desafios desse modo momento econômico.

\subsection{Breve discussão sobre o papel das Escolas Técnicas Agrícolas do Centro Paula Souza e sua trajetória histórica}

Para uma melhor compreensão sobre o papel das escolas técnicas do Centro Paula Souza, é importante voltar à reflexão para o contexto histórico que sustentou seu aparecimento e, ressaltar a relevância político-econômica que o Estado de São Paulo conquistou,ainda como Província de São Paulo, no fim do segundo reinado de D. Pedro II. Nessa época a cultura cafeeira era a base econômica e, permitia a construção de um complexo de serviços e produtos que sustentou todo o alicerce necessário para o desenvolvimento industrial.

Segundo Azevedo (1971), apud Silva; Marques (2014, p. 82), essa situação de prosperidade permitiu que o Estado de São Paulo lançasse as bases para um sistema próprio de educação, especialmente do ensino técnico agrícola, da área agropecuária. É importante destacar que foi para São Paulo que se deslocou o centro econômico, instigando ao desenvolvimento da educação pública nos seus diversos níveis e modalidades.

Nesse contexto, o Estado de São Paulo promoveu algumas iniciativas que garantiram a satisfação de um mercado de trabalho crescente e variado, que desde o fim da escravidão passou a exigir maior qualificação e algum investimento em formação de pessoal.

Esse contexto de prosperidade fez com que o Estado destinasse mais recursos na execução de políticas públicas, principalmente no que diz respeito à criação ou até mesmo transferências de instituições de competência destinada à formação profissional. Sobre esse assunto, Silva; Marques (2014, p. 83) descrevem:

Relembramos que, no período imperial, o Ensino Agrícola recebe alguma atenção, com a criação de instituições escolares destinadas à formação profissional para o setor primário. A transferência do Instituto Agronômico situado em Campinas/SP para a esfera politico-jurídica do 
estado de São Paulo muito contribuiu para o fomento do setor agrícola, bem ainda para os estudos, pesquisa e desenvolvimento de tecnologia nessa região.

A partir da República, esses investimentos na educação profissional agrícola aumentaram. Com o crescimento da mão de obra aumentou também a proposta da oferta e procura de produtos e serviços. Segundo Silva; Marques (2014, p 83):

Entretanto, é na primeira fase da República que constatamos o maior desenvolvimento e expansão do ensino técnico agrícola paulista. As mudanças no contexto político-econômico acarretam implicações no plano educacional, trazendo à tona a questão da formação profissional. Intensificam-se a oferta de serviços técnicos do setor agropecuário e incentivos à pesquisa e experimentação agrícolas. Há necessidade de ampliação de instituições para formação de profissionais de nível técnico no setor agropecuário, sedimentado na lavoura cafeeira, o pilar de sustentação da economia agroexportadora da primeira república.

No início do período republicano a lavoura do café, tendo se iniciado no Rio de Janeiro, passando pelo Vale do Paraíba, expandiu-se para o oeste paulista. Os grandes fazendeiros de café do Estado de São Paulo organizaram a infra-estrutura para a expansão e consolidação da lavoura cafeeira, propiciaram e incentivaram a construção de rede ferroviária facilitando o acesso ao porto de exportação na cidade de Santos.

Nessa perspectiva, o Estado de São Paulo tornou-se um grande promotor e difusor do Ensino Agrícola no Brasil. Outras instituições foram implantadas deixando marca do seu pioneirismo, conforme descrevem Silva; Marques (2014, p. 83):

Em 1882 foi criado o Liceu de Artes e ofícios na capital de São Paulo, que tinha por objetivo ministrar gratuitamente a formação profissional mediante 0 oferecimento de cursos relacionados às artes e ofícios incluindo cursos da área primária. Já em 1885 foi criada a Escola Agrícola "Luiz de Queiróz" em Piracicaba, subordinada à Secretaria de Agricultura, tendo sido o grande centro difusor do Ensino Agrícola no Estado de São Paulo, alcançando projeção nacional. Em 1931, mediante o decreto № 5.206, de 24/9/31 a Escola Agrícola transformouse na atual Escola Superior de Agricultura "Luiz de Queiroz", da Universidade de São Paulo.

Na verdade, é no âmbito da Secretaria da Agricultura que surgem as primeiras iniciativas de organização do ensino agrícola no Estado de São Paulo. Segundo Lourdes M. Machado (1992, p.44) com essas iniciativas "o governo do Estado de São Paulo antecede o governo federal na organização do ensino agrícola e das atividades do setor agrário da economia [...]". Já no final do século XX tem-se organizado o Serviço Agronômico do Estado, sendo prevista a criação de escolas práticas elementares de agricultura, com a instituição de distritos agrícolas sob a responsabilidade de um inspetor de agricultura. 
Com o Decreto Federal № 8.319, de 20/11/1910, houve a regulamentação efetiva do Ensino Agrícola, no Brasil. No entanto, o Estado de São Paulo criou suas primeiras instituições de Aprendizados Agrícola voltadas para formação de chefes de culturas, administração e capatazes, nas cidades de Iguape e São Sebastião. Porém, esses cursos não apresentaram êxito, em função de alguns fatores como condições de infraestrutura, desorganização administrativa e insuficiências de profissionais para conduzir os estudantes, no caso agrônomos.

No entanto, para cumprir a missão educativa do Estado de São Paulo, ao longo de sua evolução, várias intuições de educação profissional agrícola coexistiram pertencendo a diferentes órgãos gestores. Essa subordinação a diferentes órgãos dificultou a homogeneidade de um projeto político pedagógico mais consistente e alinhado no mesmo propósito, alimentando um certo grau de complexidade para a direção da gestão destas unidades de ensino. Segundo Mizoguch ${ }^{12}$ (1980), apudSilva; Marques (2014, p. 85), as instituições de ensino estavam assim divididas: 1º) O Ensino da Agricultura na Secretaria da Educação ; 2º) O Ensino Agrícola na Secretaria da Agricultura ; 3o ) A diretoria do Ensino Agrícola. Essas divisões das escolas agrícolas nesses órgãos causaram, não somente uma certa complexidade em suas respectivas administrações, como também dificultou a evolução deste tipo de ensino no Estado de São Paulo.

Em 1934, foi criada a Superintendência da Educação Profissional e Doméstica. Esse novo órgão, cujo propósito inicial seria alinhar e unificar as diretrizes e bases pedagógicas específicas para o ensino agrícola do Estado de São Paulo, seria subordinado à Secretaria Estadual de Educação, com o efeito de atender a crescente demanda do Ensino Profissional. O intuito era formar profissionais de nível médio para o setor primário da economia, unindo os componentes científicos às práticas agrícolas modernas, além de formar donas de casa com orientação para a cultura do campo.

A primeira dessas escolas foi implantada no município de Espírito Santo do Pinhal, como o nome de: Escola Profissional Agrícola IndustrialMista de Espírito Santo do Pinhal. Silva; Marques (2014, p.86) observam:

12 ShigeoMizoguchi, professor e engenheiro agrônomo, importante pesquisador e ativo protagonista do ensino agrícola, foi também autor de um importante estudo sobre o tema: Escola Fazenda: um sistema brasileiro onde o jovem aprende, trabalha e ganha. São Paulo: CENAFOR, 1980. Trabalho apresentado no Seminário Internacional de Educação, Formação Profissional e Emprego nas periferias urbanas, Salvador, 1980. 
Em 1934, é criada a Superintendência da Educação Profissional e Doméstica, órgão subordinado à Secretaria Estadual de Educação, com a finalidade de atender às necessidades crescentes do Ensino Profissional. Sua criação tinha por objetivo unificação das diretrizes gerais administrativas e pedagógicas, estabelecendo normas e critérios uniformes a serem seguidos pelas escolas profissionais do Estado de São Paulo. Foi então elaborado um plano pedagógico específico para o ensino agrícola, que objetivava a formação profissional de jovens de ambos os sexos, em técnicas e ofícios, preponderantemente manuais e mecânicos, direcionados à Agricultura. Essa Superintendência argumentou quanto à necessidade de formação profissional de técnicos da área agrícola, nos seguintes termos:

[...] nosso aparelho em ensino técnico até há bem pouco tempo limitara suas atividades em manter institutos e escolas de índole industrial e doméstica. Entretanto, a vasta zona de cultura paulista aí está a clamar a substituição dos seus condutores improvisados, por elementos aptos que tornem o labor das fazendas mais eficaz e mais de acordo com a técnica moderna. [...] Eis o fundamento que levou o Governo a ampliar o aparelho do ensino profissional com esta interessante modalidade. (MIZOGUCHI, 1980, p. 8).

Atualmente, a unidade de ensino de Espirito Santo do Pinhal faz parte do quadro das Escolas Técnicas do Centro Paula Souza, compondo as 35 escolas que mantêm cursos voltados para o setor agrícola.

Em 1942, outras instituições agrícolas foram criadas, sendo as principais: as Escolas Práticas de Agricultura pelo projeto do Dr. Fernando Costa em Ribeirão Preto, Marília, Itapetininga, Guaratinguetá, Bauru, Araçatuba, Rio Preto, Amparo, Pirassununga e, Presidente Prudente. Essas escolas tinham por objetivos somente a base prática, já que se tratavam de escolas fazenda e recebiam alunos semianalfabetos, somente de sexo masculino, o que a diferenciava das Escolas Mistas. Essas escolas não obtiveram sucesso, pois era algo bastante desgastante e oneroso administrar uma escola e ao mesmo tempo uma fazenda para o Estado e os diretores de escola.

Em 1946, aconteceu a sistematização que unificou de certa forma os projetos político-pedagógicos dessas escolas através da criação da Lei Orgânica do Ensino Agrícola, composta por três decretos. Nesse contexto, Silva; Marques (2014, p.89) descrevem:

a) Decreto-Lei no 9.613 de 20/8/1946, publicado no DOU em 23/08/96. Seu Artigo $1^{\circ}$ estabelecia "as bases de organização e de regime do ensino agrícola, ramo de ensino até o segundo grau, destinado essencialmente à preparação profissional dos trabalhadores da agricultura" (MIZOCUCHI, 197-?, p. 4); 
b) Decreto-Lei o 9.614 de 20/8/1946, publicado no Diário Oficial de 23/8/46, cujo Artigo 1을 determinava que o Ministro da Agricultura deveria fazer a expedição de instruções necessárias à imediata adaptação dos estabelecimentos de ensino agrícola, ora mantidos pelas administrações estaduais e municipais ou pelas instituições particulares, aos preceitos de organização e de regime escolar da Lei Orgânica do Ensino Agrícola, bem ainda estabelecer o processo mediante o qual esses estabelecimentos de ensino poderiam obter a equiparação ou reconhecimento. [...]. O seu parágrafo único também determinava a expedição de instruções a fim de regular o prosseguimento da vida escolar dos alunos matriculados nos estabelecimentos de ensino que, na forma do referido artigo, viessem a obter a equiparação ou o reconhecimento. (MIZOCUCHI, 197-?, p. 4);

c) Decreto oㅜ 21.667 de 20/8/1946, publicado no Diário Oficial da União de 24/8/46, que determinava o Regulamento dos Currículos de Ensino Agrícola, e que foi posteriormente substituído pelo Decreto n 38.042 de 10/10/1955.

A década de 1950, foi o período de adequação e reestruturação das escolas agrícolas perante a exigência de tais decretos. A Superintendência de Ensino Profissional passou a chamar-se Departamento do Ensino Profissional; que, por sua vez, propunha um novo projeto com ações voltadas para a revitalização da situação precária em que se encontrava as instituições agrícolas paulista. Silva; Marques (2014, p. 90), destacam:

a) criação de novas escolas e adequação do ensino aos princípios, fins e objetivos das mesmas;

b) criação de novos cursos de complementação;

c) recrutamento de profissionais habilitados (médicos veterinários, engenheiros agrônomos etc) para o corpo docente as escolas.

Dentre as ações propostas pelo Departamento de Ensino Profissional, pode-se destacar ainda a:

a) revisão e organização de novos programas de cultura geral e cultura técnica;

b) atualização de recursos didático-pedagógicos e recursos tecnológicos (equipamentos, implementos agrícolas, maquinários etc);

c) adequação das Escolas Profissionais Agrícolas Industriais Mistas de Pinhal, Jacareí e São Manuel às disposições da Lei Orgânica do Ensino Agrícola (Lei Federal oㅜ 9.613 de 20 de agosto de 1946).

Nesse processo, várias escolas foram extintas, como a de Ribeirão Preto, Marília, Itapetininga, Guaratinguetá, Bauru, Araçatuba, Rio Preto, Amparo, Pirassununga, permanecendo somente a de Presidente Prudente.

Nesse ínterim, para completar os propósitos do decreto ํㅡ 38.042 de 10/10/1955, ocorreuno Departamento de Ensino Profissional, a incorporação da Lei de n 2.663, que 
visava a mudança dos Cursos Práticos de Ensino Profissional para Escolas Artesanais ou Escolas de Iniciação Agrícola, cujos objetivos eram formar operários agrícola, com dois anos de curso. Dessa forma, permitia aos estudantes, no final do curso, a oportunidade de ingressarem no curso de Mestria Agrícola (Escolas Profissionais Agrícolas Industriais).

Nesse conjunto de adaptações as Escolas Profissionais Agrícolas Industriais Mistas foram modificadas pela Lei 2.521, de 12 de janeiro de 1954 em Escolas Agrotécnicas. $\mathrm{O}$ objetivo dessas escolas era permitir ao estudante $\mathrm{o}$ acesso ao $2^{\circ}$ ciclo de ensino com a inclusão da disciplina "Mecânica Agrícola".

Em 1956, foi extinto o Departamento de Ensino Profissional da Secretaria da Educação e o Setor de cultura Técnica Agrícola. Com isso, todas as instituições a eles ligadas foram transferidas para Secretaria da Agricultura, mais especificamente a Diretoria de Ensino Agrícola.

Em 1957, já subordinadas à Secretaria da Agricultura as Escolas de Iniciação Agrícola ofereciam o ensino de nível primário voltado para a prática agrícola, por dois anos. Nessa fase, o Estado de São Paulo passa a contar com 157 unidades de Escolas de Iniciação Agrícola, como observam Silva; Marques (2014, p. 92):

Nesse período o Estado de São Paulo passou a contar com 157 escolas de Iniciação Agrícola, subordinadas à Secretaria da Agricultura, embora nem todas essas unidades escolares tivessem sido plenamente instaladas.

A primeira das Escolas de Iniciação Agrícola a ser fundada foi a de Monte Aprazível em 1957, quando já havia sido extinto o Departamento do Ensino Profissional da Secretaria da Educação e as escolas passaram, então, a subordinar-se à Diretoria do Ensino Agrícola da Secretaria da Agricultura. No mesmo ano, 1957, também foi criada a Escola de Iniciação Agrícola de Rancharia, e em 1960 a Escola de Iniciação Agrícola de Itu. Em 1961 a criação de mais uma escola no município de Jaboticabal e, em 1962, nos municípios de Guapiassu, Bálsamo, General Salgado, Indiaporã, Jales, Macaubal, Neves Paulista e Uchoa. E em 1961 foram criadas dez Escolas de Iniciação Agrícola nos municípios de: Santa Rita do Passa Quatro, São Simão, Franca, Igarapava, Garaimbê, Pederneiras, Vera Cruz, Mirassol, Miguelópolis e Jaú.

Cabe mencionar ainda o Instituto de Zootecnia e Indústrias Pecuárias "Fernando Costa", em Pirassununga, vinculado à Faculdade de Medicina Veterinária da Universidade de São Paulo que funcionava na antiga Escola Prática de Agricultura de Pirassununga e oferecia dois cursos em nível médio (Laticínios e Zootecnia). Em 1957, esse Instituto foi transferido para a Universidade de São Paulo. No entanto, já em 1961, a situação da rede de escolas. 
A escola de Santa Rita do Passa Quatro selecionada para essa pesquisa, foi fundada oficialmente em 1963. Esse contexto ficou marcado por descontinuidades e indefinições político-administrativas, dirigidas por vários órgãos gestores ao longo de sua trajetória, como mencionado na citação acima, como Escola de Iniciação Agrícola. Convém destacar que a unidade de Santa Rita do Passa Quatro inicia suas atividades sob a égide da primeira Lei de Diretrizes e Bases da Educação Nacional, n 4.024/61, instituída em 20 de dezembro de 1961, recodificando e reestruturando o Ensino Técnico Agrícola brasileiro, que, por sua vez, no Estado de São Paulo passa novamente para a jurisdição da Secretaria da Educação.

Mesmo a mudança de órgão gestor não foi suficiente para sanar as lacunas da agricultura paulista, que estava em defasagem de novas técnicas e com a oferta de profissionais qualificados, pois o mercado demandava de forma crescente esse tipo de profissional. Assim sendo, a unidade de Santa Rita do Passa Quatro foi incluída entre os Colégios Técnicos Agrícolas, de nível médio, conforme observam Silva; Marques (2014, p. 94):

Os Colégios Técnicos Agrícolas, de grau médio, foram criados em 1968, pelo Decreto 51.094, de 16/12, em dezoito municípios paulistas: Santa Rita do Passa Quatro, São Simão, Cabrália Paulista, Cândido Mota, Cerqueira César, Franca, Graça, Igarapava, Itu, Itapetininga, Jundiaí, Miguelópolis, Mirassol, Monte Aprazível, Paranapanema, Quatá, Rancharia e Vera Cruz.

A autorização de instalação do $2^{\circ}$ Ciclo é feita pelo Secretário da Educação, através do ATO no 45 , de 28/02/69, nos municípios de Santa Rita do Passa Quatro, Monte Aprazível, Franca, Igarapava, Vera Cruz, Rancharia e Jundiaí, Presidente Prudente e "Cônego José Bento", em Jacareí.

[...] Em 1976, o Decreto Estadual no 7510 reorganiza a Secretaria da Educação e extingue a Coordenadoria do Ensino Técnico, que comportava a Diretoria do Ensino Agrícola, subordinando as escolas agrícolas à Coordenadoria de Ensino do Interior. A Resolução SE de 27/05/1977 dispôs sobre a regularização das Habilitações de Técnico Agrícola e de Técnico em Agropecuária. O Curso de Técnico em Agricultura passa se denominar Técnico Agrícola, e era oferecido em 13 escolas, conforme dispunha a supracitada Resolução:

Fica autorizado o funcionamento da habilitação de Técnico Agrícola, a partir de 1968 ou 1969, nos 13 estabelecimentos adiante mencionados, que a ministraram até 1972 ou 73: EESG Prof Luiz Pires Barbosa de Cândido Mota, EESG Carmelito Correa Júnior de Franca, EESG de Igarapava, EESG José Bonifácio de Jaboticabal, EESG Benedito Storano de Jundiái, EESG de Monte Aprazível, EESG Carolino da Mota e silva de Pinhal, EESG de Presidente Prudente, EESG de Rancharia, EESG "Manoel dos Reis Araújo" de Santa Rita do Passa Quatro, EESG de D. Sebastiana de Barros de São Manoel e EESG Paulo Guerreiro Franco de Vera Cruz. (SÂO PAULO. 1977, apud Silva; Marques, 2014, p. 95). 
Através dessas reformas, é possível identificar o tipo de formação profissional pertinente para o técnico agrícola, afim de que esse profissional possa atender aos anseios do mercado produtivo e da demanda de consumo. Assim sendo, percebe-se que o perfil do então estudante seria como na visão de Mizoguchi (1980, p. 43), apud Silva; Marques (2014, p. 96):

\begin{abstract}
Nesse sentido podem ser consideradas como ocupações básicas do técnico agrícola o planejar, o organizar, enfim administrar/gerenciar a pequena e média propriedade, de maneira autônoma ou em sistema cooperativista, tendo produtividade e equilíbrio econômico. No entanto, conforme argumenta Mizoguchi (1980, p. 43) o agricultor polivalente independente, considerado isoladamente não está completo para o desempenho de sua missão.

[...] É, pois, a família, e não o indivíduo, o agente de desenvolvimento socioeconômico [...]. Sendo assim, compete ao ensino agrícola habilitar a jovem do meio rural que como esposa ou como profissional participará, ao lado do agricultor independente polivalente, da função de agente de desenvolvimento social e econômico do meio rural.
\end{abstract}

Com base nesse contexto, a dimensão pública e política da educação profissional e tecnológica precisam ser enfatizadas permanentemente. A sua regulamentação e evolução, ao longo do tempo, têm valorizado este aspecto (SILVA, 2009). Docentes e discentes envolvidos neste processo precisam estudá-lo de forma imanente.

Pesquisar a história da educação profissional e tecnológica das Escolas Agrícolas do Centro Paula Souza é essencial para compreender a formação para o trabalho, uma vez que proporciona uma visão acurada da qualificação profissional enquanto parte da formação integral do indivíduo (DENARDI, 2014).

No quesito formação em técnico agrícola encontra-se vários fatores que contribuem para transformação de profissionais que pretendem atuar nessa área. Esses quesitos vão desde a grade dos componentes curriculares até o estereótipo dos estudantes que ingressam nesses cursos. Em princípio, por volta da década de 1960, essas escolas eram frequentadas por filhos de grande, médio e pequeno proprietário rural ou indivíduos vinculados ao agronegócio (GARCIA, 2000).

$O$ interesse de formar profissional voltado para o agronegócio era defendido inclusive por educadores da época, como é o caso do professor DrShigeoMizoguchi, que em entrevista realizada no ano de 1981, defendia: “...basicamente o ideal seria que viessem a essas escolas apenas filhos de agricultores, seja pequeno, médio ou grande. 
Mas nós recebemos realmente muitos alunos da cidade, porque os meninos da roça não conseguem fazer nem a $4^{\mathrm{a}}$ série; do $1^{\circ}$ grau."(SILVA; MARQUES 2014, p. 95)

A seguir, foto tirada do livro ponto docente 01, 03/1964, da então Escola de Iniciação Agrícola, hoje Etec Manoel dos Reis Araújo.

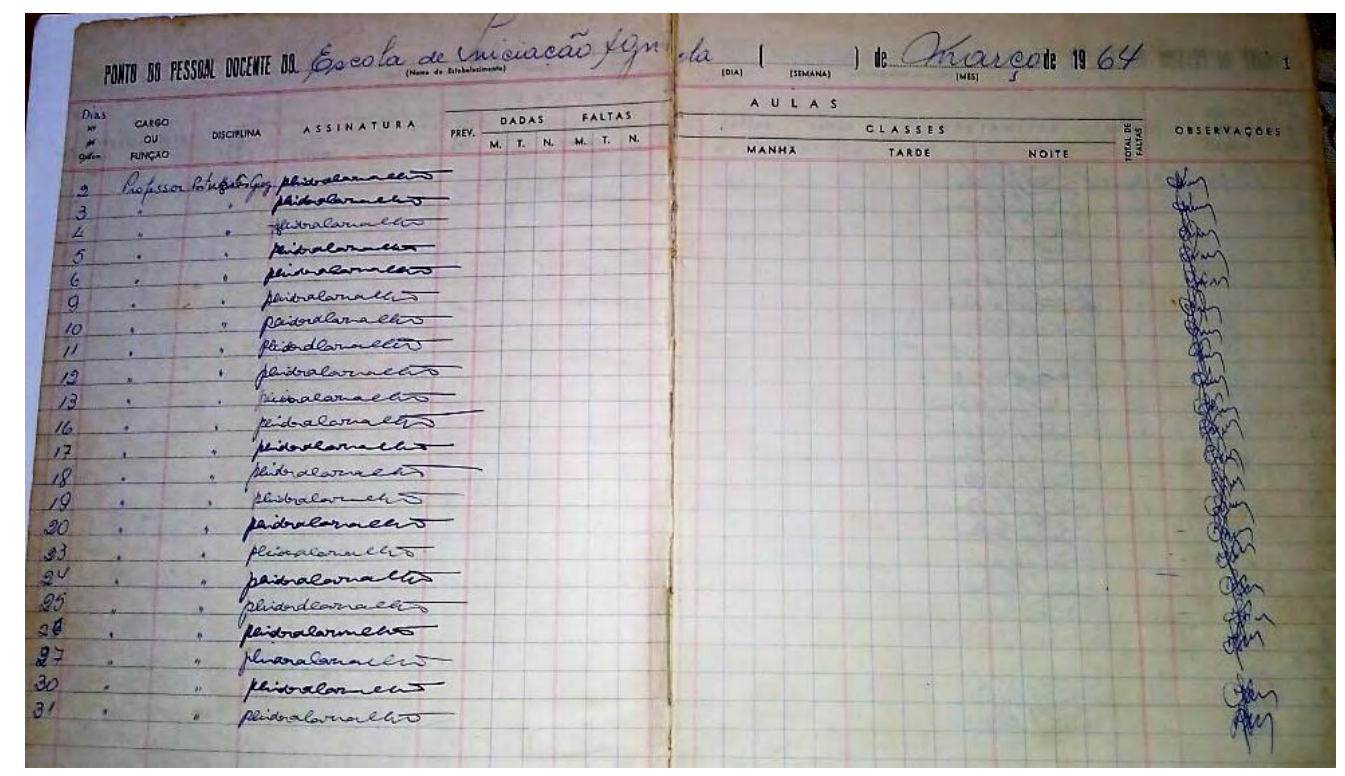

Figura 1: Livro ponto docente 01 - 03/64 a 05/69 - Pertencente ao acervo de documentos Etec Manoel dos Reis Araújo, na época Escola de Iniciação Agrícola

A Figura 1 evidencia que, em 1964, o curso já funcionava em Santa Rita do Passa Quatro e o primeiro docente a inaugurar suas páginas foi uma professora de Português, exemplificando que, além das matérias práticas, o curso de Iniciação Agrícola oferecia matérias do núcleo humanista.

Leva-se em conta que a proposta dos Planos de Cursos das ETECs para o de Ensino Médio integrado ao Técnico Agrícola tem como objetivo principal a formação dos discentes. Especificamente, busca alcançar os seguintes objetivos:

$\square \square$ planejar, executar, acompanhar e fiscaliza todas as fases dos projetos agropecuários;

$\square$ atuar na área agropecuária, prestando assistência e consultoria técnica sobre gestão da propriedade rural;

口elaborar, aplicar e monitorar programas preventivos de sanitização na produção vegetal animal e agroindústrial; .

$\square$ fiscalizar a produção de produtos de origem animal, vegetal e agroindustrial com procedimentos de biosseguridade;

$\square$ realizar medição, demarcação e levantamento topográficos rurais.

$\square$ supervisionar e realizar pesquisas e estudos de viabilidade econômica, financeira, social, política e ambiental; 
$\square$ desenvolver, implementar e disseminar tecnologias de produção agropecuária.

$\square$ implantar e gerenciar sistemas de controle de qualidade na produção agropecuária;

$\square$ identificar e aplicar técnicas mercadológicas para distribuição e comercialização de produtos;

$\square$ promover a integração e organização social no meio rural. ${ }^{13}$

Para chegar a essas bases quanto à aquisição de conhecimentos, a instituição analisou o mercado do agronegócio e o Plano de Curso do Ensino Médio integrado ao Técnico em Agropecuária, o qual foi atualizado em 2016:

A agropecuária tem um papel muito importante no Brasil, tanto no passado como no presente. É necessário saber que agropecuária remete a fusão da produção agrícola com a pecuária. Foi importante para o processo de povoamento do território brasileiro, pois na medida em que as propriedades rurais desbravavam o interior do país surgiam vilas e povoados.

A atividade agropecuária no Brasil representa $8 \%$ do PIB (Produto Interno Bruto) brasileiro e gera emprego para pelo menos $10 \%$ da população economicamente ativa do país.

A produção agropecuária tem como objetivo destinar seus produtos, tais como grãos, frutas, verduras e também carne, leite, ovos dentre outros, para abastecer o mercado interno e especialmente o mercado externo. Sem contar as matérias-primas.

São vários os fatores que favoreceu o acelerado crescimento desse tipo de produção no Brasil, dentre os principais estão:

a) grande população com perspectivas de mercado interno;

b) generosa oferta de áreas propícias ao desenvolvimento de tais atividades;

c) processo de modernização e mecanização da produção rural;

d) superfícies favoráveis à ocupação rural;

e) boa fertilidade em grande parte do território;

f) configuração climática determinante para a consolidação de culturas tropicais e criação de animais, uma vez que as temperaturas estão altas todo o ano em grande parte do território. (...)

A agropecuária brasileira está em desenvolvimento, o qual teve efeitos como a interiorização do crescimento, estabilização do abastecimento, redução do custo da cesta básica e o aumento nas exportações do

13 Centro Estadual de Educação Tecnológica Paula Souza. Plano de curso atualizado de acordo com a matriz curricular homologada para o $1^{\circ}$ semestre de 2016. Habilitação Profissional de TÉCNICO EM AGROPECUÁRIA INTEGRADO AO ENSINO MÉDIO. Lei Federal n. 9394, de 20-121996; Lei Federal n. 11741/2008; Resolução CNE/CEB n. 1, de 5-12-2014; Resolução CNE/CEB n.ำ 6, de 20-9-2012; Resolução CNE/CEB n.ํ 2, de 30-1-2012; Resolução CNE/CEB n. 4, de 13-7-2010; Resolução SE n.ำ 78, de 7-11-2008; Decreto Federal n.ํ 5154, de 23-7-2004. Plano de Curso aprovado pela Portaria Cetec - 754, de 10-9-2015, publicada no Diário Oficial de 11-9-2015 - Poder Executivo Seção I - página 54. 
setor. No novo ciclo de desenvolvimento a expectativa é de inserção definitiva do país no mercado global, minimização dos riscos ambientais, diminuição das diferenças regionais, ganhos sociais, além dos econômicos.

Algumas tendências para o Brasil também foram identificadas:

- continuada importância do agronegócio;

- nova dinâmica de desenvolvimento rural;

- redução do custo Brasil;

- crescimento do mercado interno;

- fortalecimento da agropecuária familiar;

$\square \square$ fortalecimento da política de exportação, ocupação de novos mercados e:

- ampliação da pauta de produtos exportados;

- ampliação e criação de vantagens competitivas na silvicultura;

- desenvolvimento de sistemas florestais, agroflorestais e cultivo mínimo com -- enfoque em produção e serviços ambientais;

- ampliação do uso sustentável da biodiversidade;

- novas tendências advindas da biotecnologia;

- reconfiguração profissional do agronegócio nacional. ${ }^{14}$

Assim, ao analisar o Plano de Curso, comprova-se que as "ETECs Agrícola" abordam o setor produtivo rural, ou seja, o curso Técnico em Agropecuária. A preocupação da instituição quanto à formação do discente vai além da qualificação técnica, posto competências, habilidades, valores e atitudes que são desejáveis nos profissionais ligados ao novo cenário brasileiro da agropecuária. Resta descobrir, com o decorrer da pesquisa, se este Plano é realmente eficaz ou precisa de alguns melhoramentos para atender às demandas do Agronegócio.

\subsection{Breve Histórico da ETEC Manuel dos Reis Araújo, Santa Rita do Passa Quatro - SP.}

A ETEC Manoel dos Reis Araújo é uma unidade de ensino que pertencente ao quadro das escolas do Centro Paula Souza. Localiza-se na cidade de Santa Rita do Passa Quatro, interior de São Paulo, na Avenida Paris, no 79, no Bairro Cinelândia. Atualmente, o terreno da referida escola integra mais de 20 alqueires de terras.

Segundo informações retiradas do Plano Plurianual de Gestão 2018-2022, p. $13,{ }^{15}$ que rege a gestão político administrativa do órgão, a ETEC Manuel dos Reis Araújo iniciou suas obras em 1958, durante a gestão do Prefeito Municipal Ivan Fleury

\footnotetext{
$14 \quad$ Idem nota 1, página 5 e 6

15 Disponível em: http://www.etecsantarita.com.br/Anexos/PPG-083.pdf. Consultado em $25 / 06 / 2018$
} 
Meirelles. O terreno foi doado por dois santa-ritenses: Professor Jaime Nori e DrAlciro Ribeiro Meirelles. A razão social "Escola de Iniciação Agrícola" prevaleceu até 1967. ( 2 - Atos legais de criação: Ato de Criação: Lei 7.887, publicado no DOE de 26/04/63, Decreto de integração CEETEPS: Decreto oㅜ 37.735 de 27, publicado no DOE de 28/10/93). Em 1968, em homenagem ao patrono da escola passou a denominar-se Escola de Iniciação Agrícola "Manoel dos Reis Araújo":

O patrono de nossa escola nasceu em 06 de janeiro de 1903. Era filho do jornalista Antônio José de Araújo Neto e de dona Teresa Carmelita Meireles de Araújo. Viveu na cidade de Santa Rita do Passa Quatro até os 17 anos. Cursou o grupo escolar "Francisco Ribeiro" e depois fez curso intensivo de grau secundário, iniciando nessa época atividades jornalísticas. Conta um amigo do pai de Maneco, como carinhosamente era conhecido, que o menino gostava de lidar com as terras da chácara do pai e que vendia na rua as frutas que eram produzidas no local. Formou-se jornalista. Em 1934, foi convidado a chefiar o gabinete do secretário da agricultura, Sr. Adalberto Bueno Netto, posto que exerceu até 1937, quando assumiu o cargo de sub diretor administrativo do Departamento da Produção Animal. Não escondia sua paixão pelo ensino desta área e procurou incentivar o cooperativismo. Manoel dos Reis Araújo morre em 25 de janeiro de 1966, vítima de um enfarte aos 63 anos.

Para homenageá-lo o governo de São Paulo, pelos poderes Legislativo e Executivo, promulgou a lei no 9952, de dezembro de 1967, denominando Escola de Iniciação Agrícola "Manoel dos Reis Araújo", a de Santa Rita do Passa Quatro, sua terra natal.

Em 16/12/1968, pela Lei no 51.094, as escolas de iniciação agrícola passaram a funcionar como ensino de Segundo Grau, com o nome de Colégio Técnico Agrícola Estadual, sendo que esta ação foi disciplinada pelo Ato $\mathrm{n}^{\circ} \mathbf{4 5}$, de fevereiro de $1969 .^{16}$

No final da década de 1960, a referida escola recebe verbas para implantação de um novo projeto de gestão pedagógica. A unidade escolar recebe mais alunos (500 aproximadamente) em regime de internato, sendo que essa disposição para os estudantes já existia desde 1964:

Em 1970 com o apoio da prefeitura municipal, a escola começa a passar por uma ampliação para receber mais alunos em regime de internato.

Pela resolução S.E. no 13 de 21/07/76, o Colégio Técnico Agrícola tornou-se Escola Estadual de Segundo Grau "Manoel do Reis Araújo" e posteriormente pela Resolução S.E. no120 de 21/06/85, o colégio passa a ser denominado de Escola Técnica Agrícola Estadual de Segundo Grau "Manoel dos Reis Araújo", sendo que acabou transferida da 
Secretaria da Educação para a Secretaria da Ciência, Tecnologia e Desenvolvimento Econômico, pelo Decreto Estadual 34.032 de 22/10/91.

Posteriormente, pelo Decreto № 37.735 de 27/10/93, o governador do Estado de São Paulo, Luiz Antônio Fleury Filho autoriza a transferência das Escolas Técnicas Estaduais para o Centro Estadual de Educação Tecnológica "Paula Souza". A partir daí, a Escola passa a denominar-se de Etec Manoel dos Reis Araújo - Centro Paula Souza ${ }^{17}$

De acordo com o referido texto, a partir da década de 1970 a ETEC Manuel dos Reis Araújo passa a integrar o quadro do chamado Segundo Grau da educação básica. Na década de 1990 passa a fazer parte do Centro Paula Souza.

Pela regra do Centro Paula Souza a cada quatro anos a unidade escolar elege entre seus pares o diretor da escola, que tem o dever de cumprir e zelar pela política administrativa pedagógica local.

Atualmente, a ETEC de Santa Rita do Passa Quatro, como também é conhecida, conta com outros cursos, além do Ensino Médio Integrado ao Técnico Agrícola: Ensino Técnico Integrado ao Médio em Agropecuária e Informática para Internet; técnicos em Enfermagem, Química, Recursos Humanos.

Segundo informações fornecidas pelo Plano de Gestão da escola:

No ano de 2017, tivemos concluintes do Curso Técnico em Agropecuária Integrado ao Ensino Médio ocupando cargos em várias empresas da região: Fazenda Colorado (Cidade de Descalvado), Fazenda Muller- Companhia 51 (cidade de Pirassununga), Usina São João (em Araras), Empresa Rural Particular (na cidade de Tambaú). (PLANO DE GESTÃO, ano, p. 15)

A ETEC de Santa Rita do Passa Quatro, como unidade escolar de nível médio e técnico integrante do Centro Paula Souza, juntamente com as Fatecs (Faculdade Tecnológica), tem que seguir obrigatoriamente os padrões de competências, habilidades, valores e atitudesestabelecidos pela instituição, que por sua vez, segue as Leis de Diretrizes de Bases promulgadas pelo governo Federal, sendo a última deliberada no ano de 1996.

Porém, devido às mudanças que ocorreram desde o seu projeto inicial, as Leis de Diretrizes e Bases da Educação tentam sanar a problemática educação brasileira, conforme foi abordado em parágrafos anteriores, sob suas perspectivas de aplicação prática quanto à sua validade para o ensino técnico agrícola.

$17 \quad$ Idem nota 24 p. 15 
Dentro desse viés de compromissos, cada unidade da ETEC estabelece sua missão social, levando em consideração os cursos oferecidos à comunidade local e o perfil do alunado. No caso da ETEC de Santa Rita do Passa Quatro, pretende-se cumprir a seguinte missão, segundo Plano de Gestão (2018-2022, p. 4, 5 e 6):

\section{2- Valores e crenças:}

Durante o ano de 2017, priorizamos a melhora no rendimento dos alunos e a diminuição no índice de PP's( Progressões Parciais), o que resulta no aumento, ainda tímido, da qualidade de aprendizagem. Isso foi possível com um trabalho de acompanhamento efetivo e individualizado dos discentes por parte da Orientadora Educacional, dos Coordenadores de área, dos professores, da Equipe Gestora e funcionários como um todo.

Em 2018, buscaremos como valor essencial a participação dos alunos no ambiente escolar. Participação esta que não se restringe a estar na sala de aula ou em eventos como simples espectadores, porém, em serem protagonistas nos diferentes segmentos da Etec.

Temos como crença o ideal de que a gestão participativa é o melhor caminho a ser seguido.

\section{3- Princípios Pedagógicos:}

Capacitar os professores motivando-os a reconhecerem as dificuldades comuns ao magistério na contemporaneidade e a refletirem sobre formas de ultrapassar os diferentes obstáculos.

Capacitar professores, através de reuniões agendadas em calendário ou feitas individualmente, sobre a importância de motivar os alunos a participarem como agentes no ambiente escolar, utilizando-se de diferentes metodologias de aprendizagem, que promovem a ação discente.

Capacitar os docentes, também, sobre o apoio necessário para com o discente no processo de avaliação e recuperação, tornando-o transparente e facilitador.

Capacitar os funcionários para que estes também se sintam parte do processo de ensino- aprendizagem, estando cientes de seu papel como educadores e auxiliares da ação docente, trabalhando em conjunto, porém, com autonomia e favorecendo abertura para que o aluno participe do ambiente escolar.

Orientar o Grêmio Estudantil sobre sua importância e possibilidades de atuação dentro da Etec, como representação ATIVA os discentes, acompanhando desde a eleição, para que seja feita de modo consciente, até a execução das tarefas.

Reunir cooperativa escola e equipe docente do Curso Técnico em Agropecuária, de modo que haja o diálogo constante entre as partes e que sejam planejadas ações que envolvam os discentes nas diversas atividades produtivas da escola.

Selecionar alunos para a formação de comitês de discentes responsáveis por auxiliar na resolução de conflitos e na organização do espaço sala de aula e laboratórios, além de áreas livres, para que desenvolvam o cuidado com o ambiente escolar e sejam amenizadas ações que depredem o patrimônio público (escrita em carteiras, paredes, vitros, entre outros).

Realizar reuniões, juntamente com o coordenador de curso e a Orientadora Educacional, com os alunos com excesso de faltas, 
registrando em atas os motivos e o comprometimento na resolução dos problemas por parte dos alunos.

Propor eventos com a participação dos discentes e dos docentes e funcionários, para que seja incentivada a integração entre os diferentes segmentos da U.E. e para que haja a cooperação entre as partes.

Capacitar docentes sobre o processo de Inclusão na Etec, para que compreendam o papel do educador como aquele que acolhe e respeita as diferenças, priorizando o relacionamento interpessoal e combatendo a intolerância às diferenças.

Perante o contexto discutido, no que se refere à constituição e consolidação da performance educacional da ETEC Manoel dos Reis Araújo, observa-se que permite como prioridade a formação dos educandos, condizente com a realidade da vida e da área escolhida para qualificação técnica.

Assim sendo, essa unidade de ensino se mostra eminente e pertinente para trilhar as propostas do presente estudo, tendo como foco a investigação sobre o perfil profissional do estudante ingresso, habilitado nas competências e habilidades do ensino aprendizagem estabelecido com muita pauta, democracia e rigor, visando atingir o segmento do agronegócio. O conteúdo a seguir descreve a metodologia adotada para o desenvolvimento dessa pesquisa. 


\section{METODOLOGIA}

De acordo com Spink e Menegon (2013, p.44), o método científico é um conjunto de concepções sobre a natureza, sobre o ser humano e sobre o seu próprio conhecimento, embasando os procedimentos utilizados na construção de um novo conhecimento, agora de caráter científico.

Para as autoras, a validade científica pode ser obtida tanto pelo método quantitativo quanto pela análise qualitativa, mostrando que crescentemente nas ciências sociais as metodologias coexistem e a abordagem qualitativa encontra respaldo teórico para o tratamento dos dados.

Desse modo, a prática de pesquisa resulta da junção de diversos saberes e fazeres científicos, que promovem uma prática crítica, reflexiva, direcionada também para a prática social.

Pode-se, então, compreender a metodologia de uma pesquisa como um conjunto de técnicas teórico-práticas que contemplam as ciências em geral, de modo a auxiliá-las na sua formação de questionamentos e de possíveis interpretações sobre a realidade. É considerada, em grande medida, o elemento epistemológico de construção de como pode ser conduzida a escrita da dissertação. Considera-se que os métodos são os caminhos que se trilha a composição do conhecimento científico ao buscar fundamentos empíricos. (SILVA, 2008)

Para atender a conjuntura da proposta desta pesquisa, no que diz respeito aos aspectos metodológicos pretende-se usar dados quantitativos, os quais baseiam-se nos dados estatísticos oferecidos pelas Etecs, Escolas Técnicas do Centro Paula Souza, e os qualitativos, retirados das entrevistas com os estudantes, professores das matérias práticas, e proprietários rurais locais para identificar 0 atual perfil desse discente do curso do Ensino Médio Integrado ao Técnico em Agropecuária se está em consonância com as necessidades do mercado do agronegócio.

A recorrência da utilização dos dois métodos, qualitativo e quantitativo, está vinculada ao fato de os dados oferecidos por um ser completado ou confirmado por outro. Pode-se concluir como observa Skate (1983, p 21 apud: SILVA, 2008, p 26) que os elementos recolhidos em ambas pesquisas se completam:

(...) determinados momentos, lugares ou pessoas passam a ser o centro do enfoque. 
A sua singularidade, ironicamente, pode ser considerada como base para acompreensão do típico e do geral. Em estudos quantitativos, a singularidade individual é tratada como variância do erro. Ao contrário, na pesquisa naturalista, o problema é investigado mais cuidadosamente. (STAKE, 1983, p. 21 apud: SILVA, 2008, p 26).

Nas pesquisas qualitativas, segundo Ramos (2017), o pesquisador busca conhecer opiniões e atitudes para descrever situações. As questões a investigar não se estabelecem mediante a operacionalização de variáveis, mas são previamente formuladas com o objetivo de estudar fenômenos complexos em contexto natural (MEIRINHOS; OSORIO, 2010, apud RAMOS, 2017). Já em pesquisas quantitativas, há a reunião, registros e análise de dados numéricos que se referem às atitudes e aos comportamentos de um público-alvo através uma amostra e/ou espaço amostral (HAIR et al. 1998, apud RAMOS, 2017).

No caso das entrevistas, como pretendem valorizar as experiências vividas pelos estudantes, quanto à aquisição de competência e habilidades oferecidas pelo curso, sua utilização é fundamental para mapear as práticas, valores e o sistema de uma forma geral, além de entender o universo social que os atores estão compartilhando. É importante ressaltar que a entrevista é um trabalho árduo e imparcial, porém não um bate papo informal. Segundo Duarte (2004, p. 15):

(...) realizar entrevistas de forma adequada e rigorosa não é mais simples do que lançar mão de qualquer outro recurso destinado a coletar informações no campo: talvez elas tomem menos tempo na fase preparatória do que a elaboração de questionários ou checklist por exemplo, mas para serem realizadas de modo a que forneçam material empírico rico e denso o suficiente para ser tomado como fonte de investigação, demandam preparo teórico e competência técnica por parte do pesquisador.

Levando em consideração o parecer desse autor, o pesquisador deve reconhecer que o homem não é um ser passivo e interpreta o mundo em que vive continuamente, atuando com muita propriedade sobre o conjunto evolutivo de sua espécie. Sob esse aspecto, que utiliza o ser humano como objeto, existem estudos chamados de Interpretacionistas, recorrentes do método qualitativo, conforme observa Oliveira (2008, p. 03): 
O outro posicionamento metodológico para se fazer pesquisa é o que defende o estudo do homem, levando em conta que o ser humano não é passivo, mas sim que interpreta o mundo em que vive continuamente. Esse ponto de vista encaminha os estudos que têm como objeto os seres humanos aos métodos qualitativos, sendo chamado de Interpretacionismo. Os estudiosos que se dedicam a esse tipo de pesquisa são chamados de interpretacionistas e afirmam que o homem é diferente dos objetos, por isso o seu estudo necessita de uma metodologia que considere essas diferenças. Nesse posicionamento teórico, a vida humana é vista como uma atividade interativa e interpretativa, realizada pelo contato das pessoas. Os procedimentos metodológicos, então, são do tipo etnográfico como, por exemplo: observação participante, entrevista, história de vida, dentre outros.

Esse método de interpretação dos discursos obtidos através de entrevistas também é chamado pelos historiadores, profissionais responsáveis pela pesquisa histórica, de história oral, procedimento já discutido em outro capítulo.

A realização de uma entrevista não é, portanto, uma tarefa banal. Segundo Duarte (2004, p. 216):

a) que o pesquisador tenha bem definidos os objetos de pesquisa; b) que ele conheça com alguma profundidade 0 contexto em que pretende realizar sua investigação (a experiência pessoal, conversa com as pessoas que participar daquele universo- egos focais/informantes privilegiados -, leitura de estudos precedentes e uma cuidadosa revisão bibliográfica são requisitos fundamentais para a entrada do pesquisador no campo); c) a introjeção, pelo entrevistador, do roteiro da entrevista (fazer uma entrevista "não-válida" com o roteiro é fundamental para evitar "engasgos" no momento da realização das entrevistas válidas); d) segurança e autoconfiança; e) algum nível de informalidade, sem jamais perder de vista os objetivos que levaram a buscar aquele sujeito específico como fonte de material empírico para sua investigação.

Quanto ao procedimento de analisar as pesquisas também é uma tarefa que exige muita atenção por parte do pesquisador. Duarte (2004, p.216) descreve que:

[...] exige muito cuidado com a interpretação, a construção de categorias e, principalmente, com uma tendência bastante comum entre pesquisadores de debruçar-se sobre o material empírico procurando 'extrair' dali elementos que confirmem suas hipóteses de trabalho e/ou os pressupostos de suas teorias de referência. Precisa-se estar muito atento à interferência de nossa subjetividade, ter consciência dela e assumi-la como parte do processo de investigação. 
No caso da subjetividade obtida nas entrevistas com os sujeitos que envolvem o universo pedagógico convém observar, segundo Cappelle; Silva (2013, p. 02), que apesar de tratar-se de questionamentos com propósitos de maximização de resultados, sempre haverá algo a mais escondidos nas entrelinhas desse movimento de busca da subjetividade dos indivíduos. Também, há desenvolvimentos teóricos dentro dos diálogos dos entrevistados capazes de fornecer subsídios para uma compreensão mais abrangente da inserção das pessoas no mundo do trabalho.

Dessa maneira, Rey (2003, p. 240), apudCappelle; Silva (2013, p. 02), analisa:

A teoria da subjetividade assumida por se orientar para uma apresentação da subjetividade que em todo o momento se manifesta na dialética entre o momento social e o individual, em que o momento individual está representado por um sujeito comprometido permanentemente no processo de suas práticas sociais, de suas reflexões e de seus sentidos subjetivos.

Sendo assim, as entrevistas são imprescindíveis no caso do presente estudo, pois favorecem o desenvolvimento de um projeto que busca crenças, valores, práticas e sistema classificatório de universos sociais específicos de sujeitos envolvidos na mesma finalidade, buscando a qualificação profissional para atender anseios pessoais de futuro (DUARTE,2004)

Quanto ao método quantitativo que será utilizado para observação dos números estatísticos fornecidos pelo Centro Paula Souza, será definido: "[...] a Pesquisa Quantitativa caracteriza-se pelo emprego de instrumentos estatísticos, tanto na coleta como no tratamento dos dados" (DUARTE; LAMONIER; COLAUTO, 2008, p. 256, apud: COSTA; CLEMENTE; CRUZ; GLAUSSNER; LOURENÇO, 2010, p.04 ).

Trata-se de um processo de coleta numérica, combinado com teorias e cálculos matemáticos, sem a interferência direta dos indivíduos observados, que serão investigados para quantificar e mensurar a relevância da pesquisa. O objetivo de tal trabalho é apontar preferências, comportamentos, e outras ações dos indivíduos que pertencem a determinado grupo ou sociedade em geral.

Nesse sentido, Günther (2006, p. 03) ressalta que através da pesquisa quantitativa "tenta-se obter um controle máximo sobre o contexto, inclusive produzindo ambientes artificiais com o objetivo de reduzir ou eliminar a interferência de variáveis interferentes e irrelevantes" para apresentar resultados mais precisos no final. 


\section{RESULTADOS E DISCUSSÂO}

\subsection{Análise Quantitativa}

A análise dos dados para cumprir com os propósitos desse trabalho inicia-se com a utilização de números obtidos para a formação do Plano Plurianual de Gestão,2018-2022, p. 15, referente à demanda nos Cursos Técnicos. Pretende-se uma demanda mínima de 02 alunos por vaga. Esse número foi atingido em 2017 e, existe a expectativa de que esses números continuem subindo.

\section{Agropecuária}

$\begin{array}{lccc}\text { Semestre } & \text { Inscritos } & \text { Vagas } & \text { Demanda } \\ 1 / 17 & 82 & 40 & 2,05 \\ 1 / 16 & 57 & 40 & 1,43 \\ 1 / 15 & 45 & 40 & 1,13 \\ 1 / 14 & 36 & 40 & 0,9 \\ 1 / 13 & 41 & 40 & 1,03 \\ 1 / 10 & 31 & 40 & 0,78\end{array}$

\section{Formandos - Agro}

\section{Ano Término Início \% Formado}

$\begin{array}{llll}14 \text { a } 16 & 36 & 35 & 1,03 \\ 13 \text { a } 15 & 27 & 32 & 0,84 \\ 10 \text { a } 12 & 12 & 32 & 0,38\end{array}$

Fonte: Plano Plurianual de Gestão 2018-2022, p. 05

Verifica-se que os números referentes à demanda do curso do Ensino Médio Integrado ao curso de Agropecuária, vêm se recuperando lentamente. É importante lembrar que essa proposta do Ensino Médio Integrado ao curso técnico foi retomada há pouco tempo, tendo sido apoiada com maior ênfase, pelo governo estadual, a partir de 2013.

Segundo informação da secretaria da escola Manoel dos Reis Araújo, o ensino básico integrado ao técnico teve sua última turma formada em 2003.Somente nos anos 2010, foi retomado com o plano de expansão das Etecs, do Centro Paula Souza, devido a identificação da demanda de profissionais qualificados nessa área para 0 mercado de trabalho. 
Através dessa proposta educacional, que envolve o ensino técnico integrado ao médio, o estudante entra nas escolas às $7 \mathrm{~h}$ e permanece até às $15 \mathrm{~h}$ diariamente, de segunda a sexta-feira. São oferecidos alojamentos para os que residem em outras cidades, porém o regime de internato não é obrigatório. Para os residentes na escola são oferecidas 05 refeições diárias.

Dessa maneira, pelo Plano de Curso oferecido pelo Centro Paulo Souza para as Etecs que oferecem esse tipo de formação, os educandos cumprem 4207 horas de estudos, divididos em três séries de tempo integral e, mais 120 horas com o Trabalho de Conclusão de Curso.

A Matriz Curricular é composta por matérias do núcleo básico: Português, Matemática, História, Geografia, Biologia, Artes, Física, Química, Inglês, Educação Física, Sociologia, Filosofia e por componentes voltados para área técnica: Nutrição Vegetal, Uso Sustentável do Solo e da Água, Plano de Negócios Agropecuário, Microbiologia e Botânica, Planejamento de Desenvolvimento de Trabalho de Conclusão de Curso, etc. ${ }^{18}$

Os estudantes cumprem algumas tarefas relacionadas à fazenda, que vão desde o plantio até a sondagem e manutenção da pocilga, curral, granja, cuja finalidade é o desenvolvimento do Trabalho de Conclusão de Curso, o qual deve ser entregue no final do curso como pré-requisito para receber o certificado.

Outra preocupação da unidade de Santa Rita do Passa Quatro, quanto à formação dos discentes, está vinculada aos dados quantitativos fornecidos pelos SARESP ${ }^{19}$.

A Tabela 1 faz referência a participação dos alunos na prova do Saresp.

\footnotetext{
18 Matriz Curricular segue nos anexos

19 O Sistema de Avaliação de Rendimento Escolar do Estado de São Paulo (Saresp) é aplicado pela Secretaria da Educação do Estado de São Paulo com a finalidade de produzir um diagnóstico da situação da escolaridade básica paulista, visando orientar os gestores do ensino no monitoramento das políticas voltadas para a melhoria da qualidade educacional. No Sistema

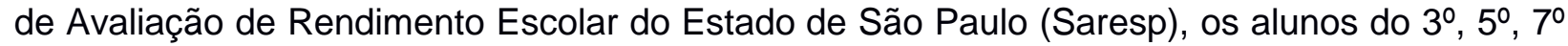
e $9^{\circ}$ anos do Ensino Fundamental e da $3^{\text {a }}$ série do Ensino Médio têm seus conhecimentos avaliados por meio de provas com questões de Língua Portuguesa, Matemática e redação. Os resultados são utilizados para orientar as ações da Pasta e também integram o cálculo do Índice de Desenvolvimento da Educação do Estado de São Paulo (Idesp). Disponível em: http://www.educacao.sp.gov.br/saresp. Consultado em: 01/10/218.
} 
PARTICIPAÇÃO DOS ALUNOS NO SARESP 2016

\begin{tabular}{|l|c|c|c|c|c|c|c|}
\hline \multicolumn{1}{|c|}{ INSTÄNCIAS } & $\mathbf{3}^{\circ} \mathrm{EF}$ & $\mathbf{5}^{\circ} \mathrm{EF}$ & $\mathbf{7}^{\circ} \mathbf{E F}$ & $\mathbf{9}^{\circ} \mathrm{EF}$ & $\mathbf{3}^{\circ} \mathrm{EM}$ & \multicolumn{2}{c|}{ TOTAL } \\
\hline ESTADO & 153.443 & 152.538 & 43.971 & 331.631 & 370.451 & $\mathbf{1 . 0 5 2 . 0 3 4}$ & 84,8 \\
\hline REDE ESTADUAL & 118.656 & 120.355 & 39.354 & 327.604 & 350.851 & 956.820 & 84,4 \\
\hline DIRETORIA DE ENSINO & 460 & 423 & 548 & 2.578 & 2.574 & 6.583 & 85,1 \\
\hline ESCOLAS DO CENTRO PAULA SOUZA & - & - & - & - & 19.451 & 19.451 & 85,0 \\
\hline ESCOLA & - & - & - & - & 65 & 65 & 94,2 \\
\hline
\end{tabular}

Referência: alunos presentes no $1^{\circ}$ dia de avaliação

- Escolas do Centro Paula Souza que participaram do SARESP 2016: 200 escolas.

Fonte: Disponível <http://www.educacao.sp.gov.br/saresp. > Acesso em: 01/10/2018

Essa prova aplicada aos alunos da terceira série avalia o nível de desenvolvimento e aprendizagem das matérias do núcleo básico: Português e Matemática.

A Tabela 2 a seguir refere-se ao nível de desenvolvimento e aprendizagem dos estudantes da Etec na disciplina de Português:

\begin{tabular}{|c|c|c|c|c|c|c|}
\hline \multicolumn{7}{|c|}{ 3" SÉAIE DO ENSINO MÉDIO } \\
\hline CLASSIFICAÇĀO & \multicolumn{2}{|c|}{ NIVEL } & $\begin{array}{c}\text { REDE } \\
\text { ESTADUAL }\end{array}$ & $\begin{array}{l}\text { DIRETORIA } \\
\text { DE ENSINO }\end{array}$ & $\begin{array}{c}\text { ESCOLAS DO } \\
\text { CENTRO PAULA SOUZA }\end{array}$ & ESCOLA \\
\hline Insuficiente & Abaixo do Básico & $<250$ & 30,9 & 26,2 & 7,6 & 36,4 \\
\hline \multirow{3}{*}{ Suficiente } & Básico & $250 a<300$ & 37,0 & 39,9 & 17,4 & 34,8 \\
\hline & Adequado & $300 a<375$ & 31,3 & 33,1 & 69,0 & 27,3 \\
\hline & Básico + Adequado & & 68,4 & 73,0 & 86,4 & 62,1 \\
\hline Avançado & Avançado & 2375 & 0,8 & 0,8 & 6,0 & 1,5 \\
\hline
\end{tabular}

Fonte: Disponível <http://www.educacao.sp.gov.br/saresp. > Acesso em: 01/10/2018

Segue o Gráfico 1 que faz uma comparação do percentual de alunos níveis da escala de proficiência no SARESP, 2014 a 2016, em Língua Portuguesa. 


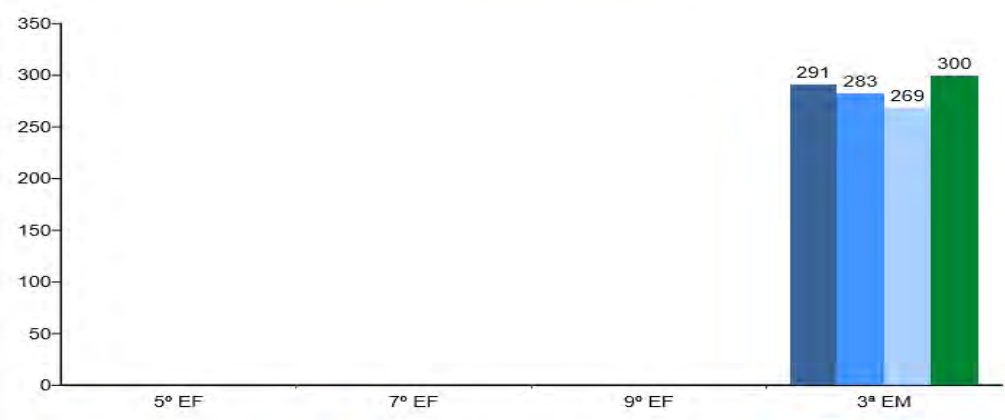
II 2014
2015
2016
meta esperada

Comparação do percentual de alunos nos níveis da Escala de Proficiência no SARESP 2014 a 2016

Fonte: Disponível <http://www.educacao.sp.gov.br/saresp. $>$ Acesso em: 01/10/2018

No Gráfico 2 observa-se ainda uma Comparação do percentual de alunos níveis da escala de proficiência no SARESP, 2014 a 2016.

\section{Comparação do percentual de alunos nos níveis da Escala de Proficiência no SARESP 2014 a 2016}

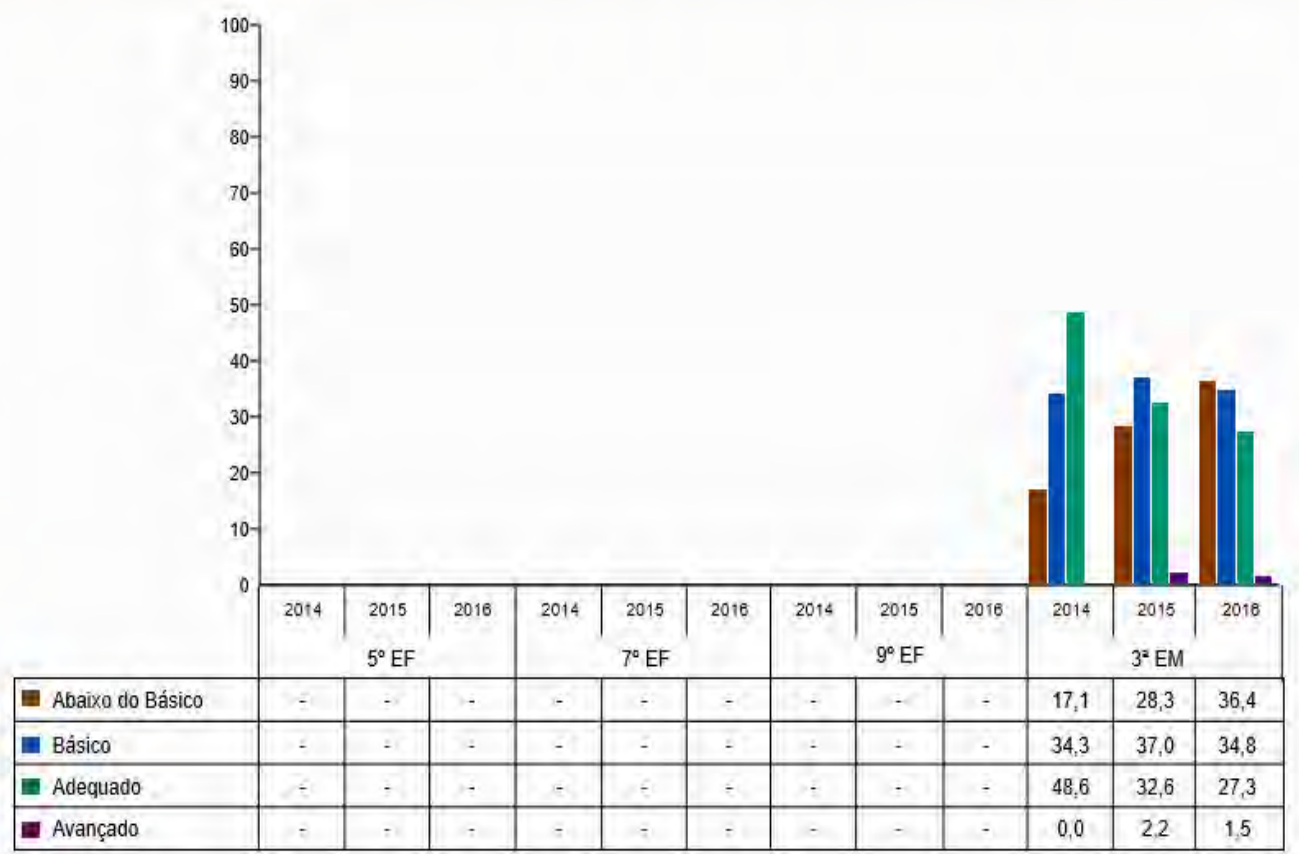

Fonte: Disponível <http://www.educacao.sp.gov.br/saresp. >Acesso em: 01/10/2018

$\mathrm{Na}$ Tabela 3 segue os dados sobre a do nível de desenvolvimento e aprendizagem, em Matemática: 


\begin{tabular}{|c|c|c|c|c|c|c|}
\hline \multicolumn{7}{|c|}{ 3" SÉRIE DO ENSINO MÉDIO } \\
\hline CLASSIFICAÇÃO & \multicolumn{2}{|c|}{ NIVEL } & $\begin{array}{l}\text { REDE } \\
\text { ESTADUAL }\end{array}$ & $\begin{array}{l}\text { DIRETORIA } \\
\text { DE ENSINO }\end{array}$ & $\begin{array}{c}\text { ESCOLAS DO } \\
\text { CENTRO PAULA SOUZA }\end{array}$ & ESCOLA \\
\hline Insuliciente & Abaixo do Básico & $<275$ & 47,6 & 43,0 & 10,4 & 44,6 \\
\hline \multirow{3}{*}{ Suficiente } & Básico & $275 a<350$ & 47,4 & 51,2 & 54,7 & 50,8 \\
\hline & Adequado & $350 a<400$ & 4,8 & 5,7 & 31,2 & 4,6 \\
\hline & Básico + Adequado & & 52,2 & 56,9 & 85,9 & 55,4 \\
\hline Avançado & Avançado & $\geq 400$ & 0,3 & 0,1 & 3,8 & 0,0 \\
\hline
\end{tabular}

Fonte: Disponível <http://www.educacao.sp.gov.br/saresp. $>$ Acesso em: 01/10/2018

No Gráfico 3 segue a comparação do percentual de alunos níveis da escala de proficiência no SARESP, 2014 a 2016, e com a meta esperada no Saresp.
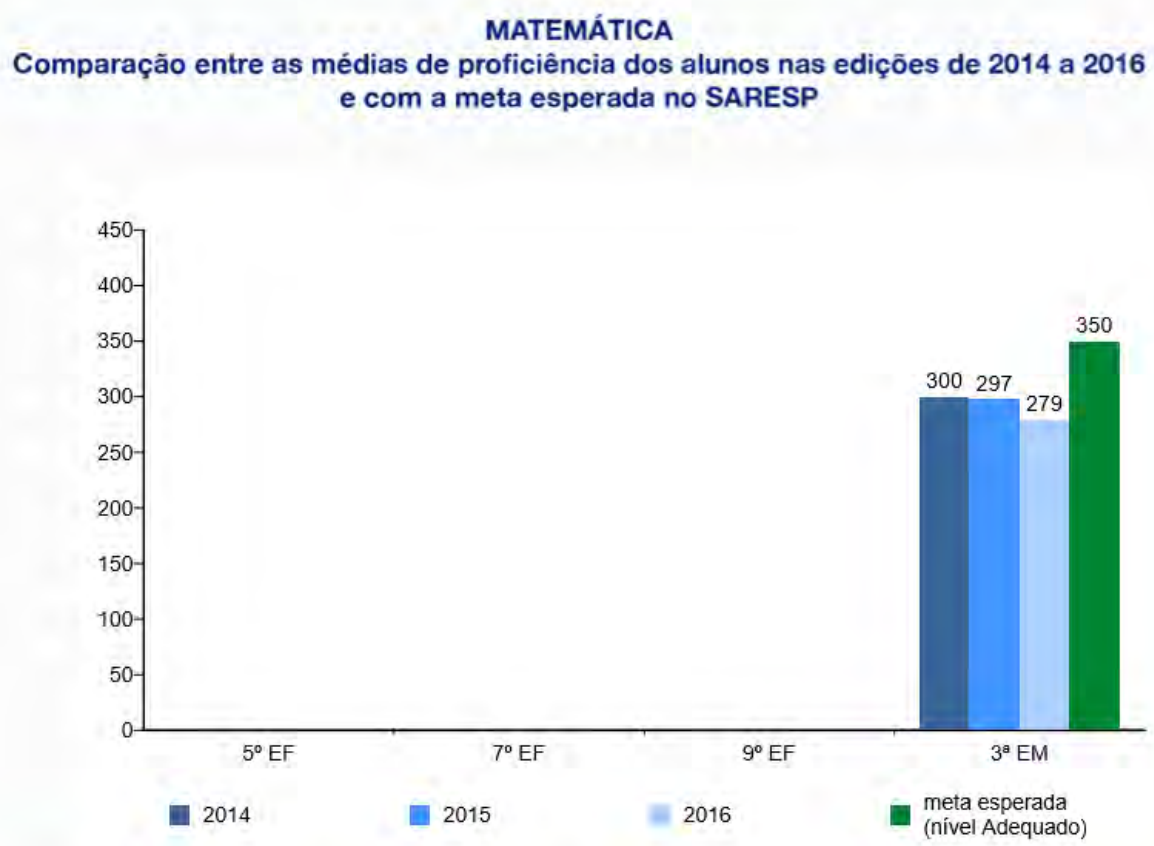

Comparação do percentual de alunos nos niveis da Escala de Proficiência no SARESP 2014 a 2016

Fonte: Disponível <http://www.educacao.sp.gov.br/saresp. $>$ Acesso em: 01/10/2018

O Gráfico 4 demonstra uma comparação do percentual de alunos níveis da escala de proficiência no SARESP, 2014 a 2016, em Matemática. 


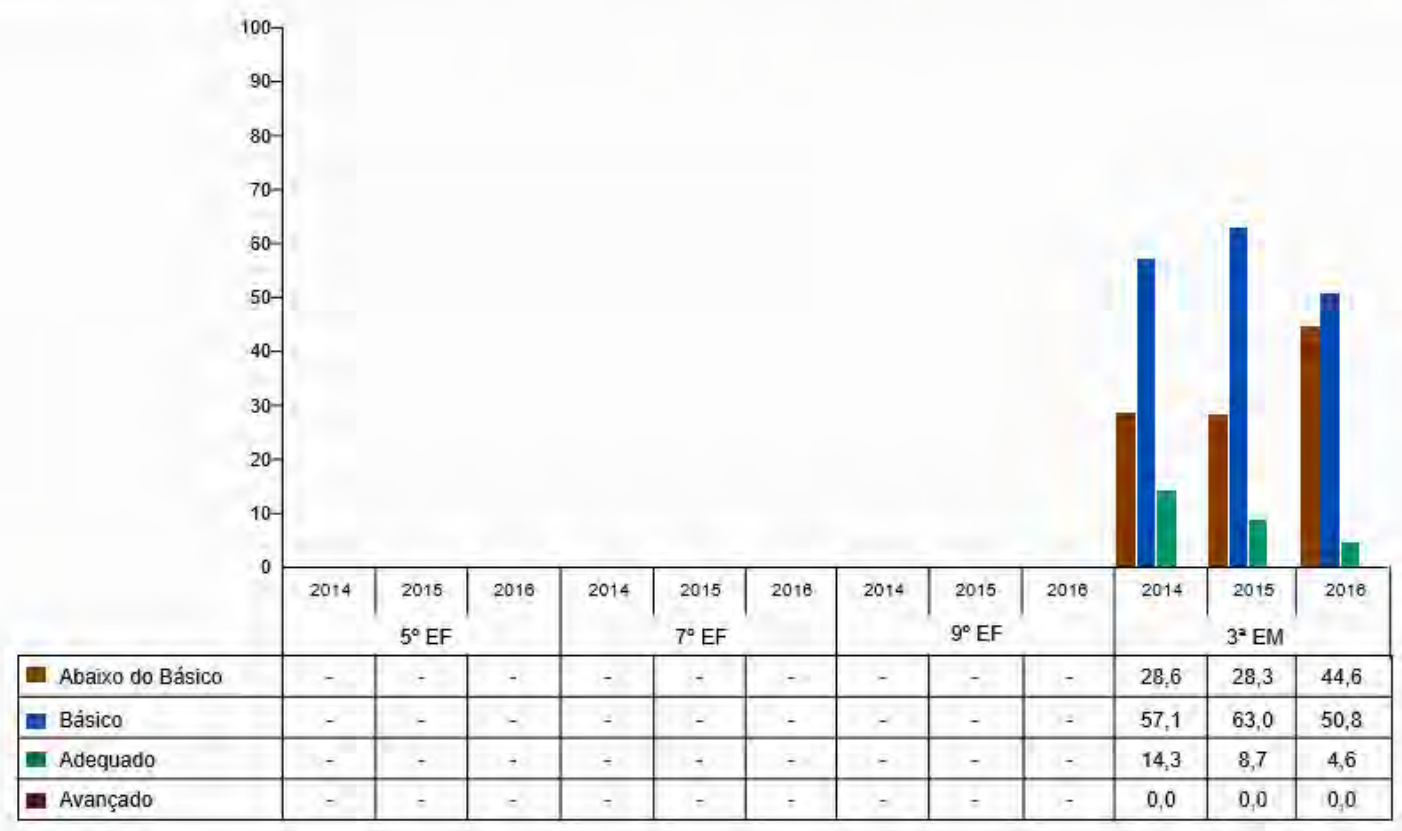

Fonte: Disponível <http://www.educacao.sp.gov.br/saresp. $>$ Acesso em: 01/10/2018.

Observa-se pelos gráficos 1, 2, 3 e 4, que essas disciplinas apresentam números de defasagem muito grande, o que torna bastante preocupante e aumenta a responsabilidade técnico pedagógica da instituição quanto ao nível de melhoramento nos procedimentos que compõe a formação do estudante.

Para tanto, ações foram embutidas no Plano Plurianual de Gestão da escola, visando atender o aprimoramento da aprendizagem das ferramentas utilizadas na vida social e profissional do educando, o Português e a Matemática.

Essas ações oferecidas pela unidade ensino são pautadas na constituição de parcerias do corpo docente, com a equipe pedagógica e alunos, nas quais se disponibilizam monitorias e plantão de dúvidas diários após aulas, ou em horários estratégicos, sobre as disciplinas que apresentam níveis dificuldades maiores, para conjuntamente melhorarem o desempenho cognitivo. 
Um outro recurso quantitativo a que esta pesquisa recorreu, foi a aplicação de um questionário socioeconômico, utilizando o recurso do Googledocs $^{20}$, respondido na ocasião por 35 alunos:

1) Sexo?
35 respostas

2) Como você se considera?

35 respostas

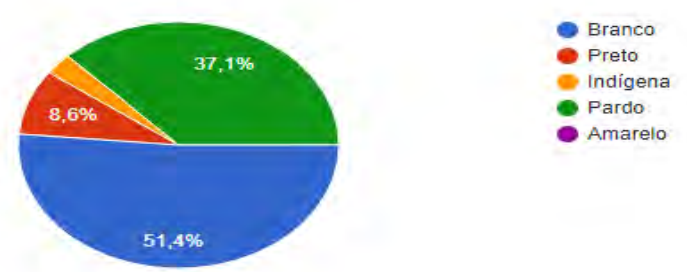

3) Qual é o mês do seu aniversário?

35 respostas

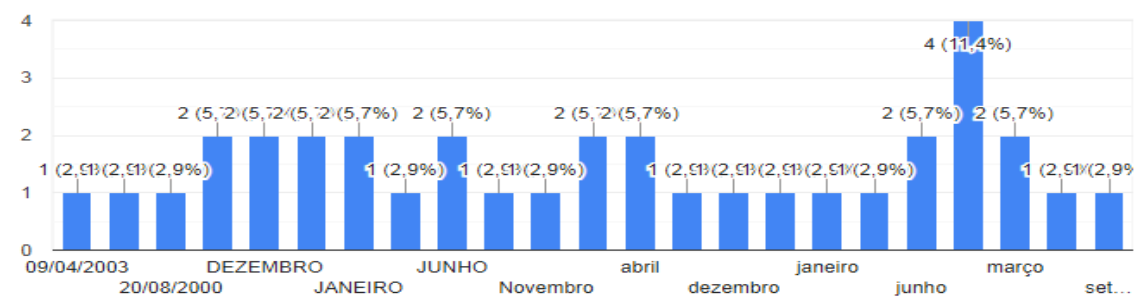

4) Em que ano você nasceu?

35 respostas

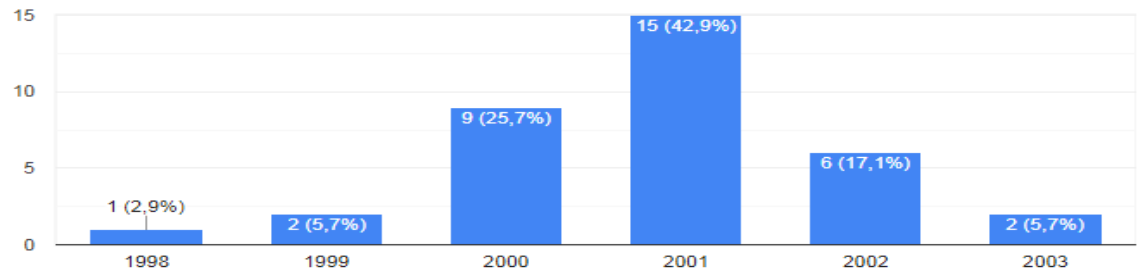

20 Disponível em:

https://docs.google.com/forms/d/1VNFjWIGB h9HADzJfJeSMwvE9 Twj sL8xXvWmj6uM/edit. Acessado em: 05/11/2018. 
5) Na sua casa tem televisão?

35 respostas

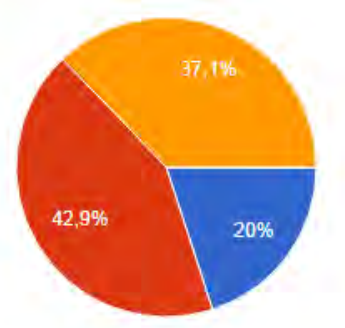

- Sim, uma

- Sim, duas

- Sim, três ou mais

- Não tem

6) Na sua casa tem radio?

35 respostas

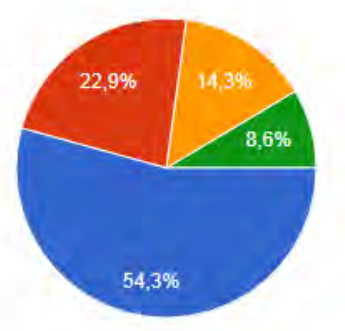

- Sim, uma

- Sim, duas

- Sim, três ou mais

- Não tem

7) Na sua casa tem DVD?

35 respostas

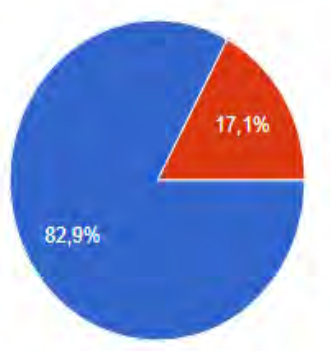

C Não

8) Na sua casa tem geladeira?

35 respostas

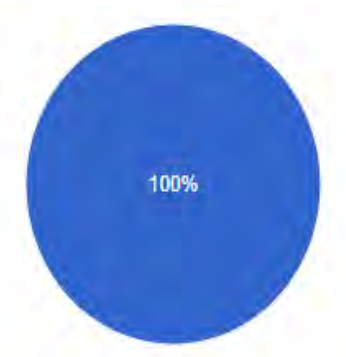

Sim

- Não 
9) Sua casa é própria?

35 respostas

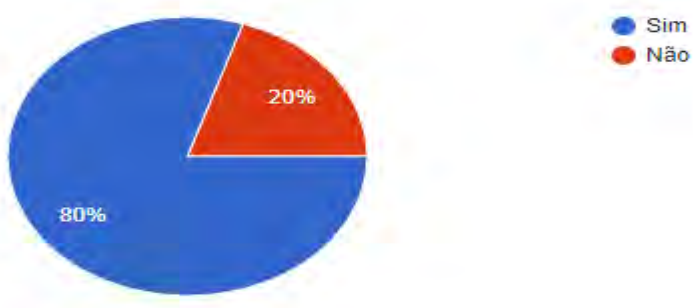

10) Quantas pessoas moram na sua casa contando com você?

35 respastas

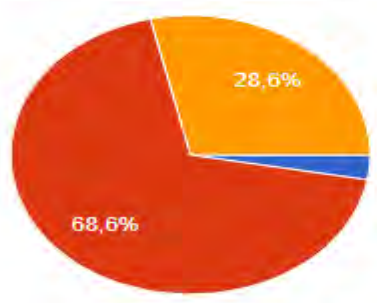

- 1 a 2

- 5 ou mais

11) Na sua casa tem carro?

35 respostas

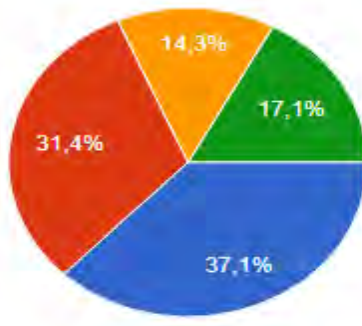

- Sim, um

- Sim, dois

Sim, três ou mais

- Não tem

12) Na sua casa tem computador?

35 respostas

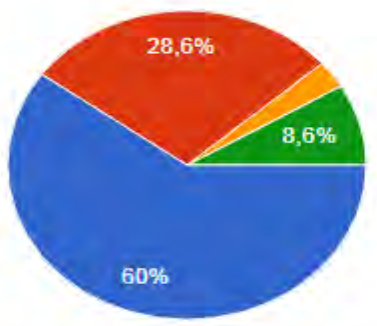

Sim, um

- Sim, dois

Sim, três ou mais

- Não tem 
13) Na sua casa tem internet?

35 respostas

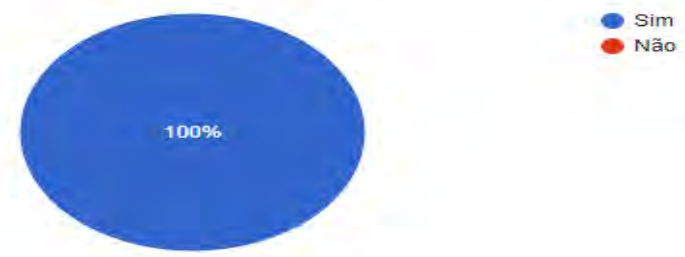

14) Você tem celular?

35 respastas

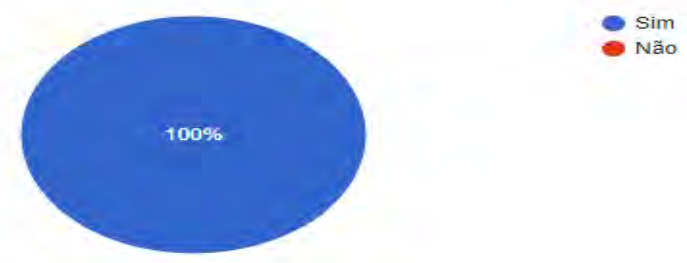

\section{Modelo de Celular}

35 respostas

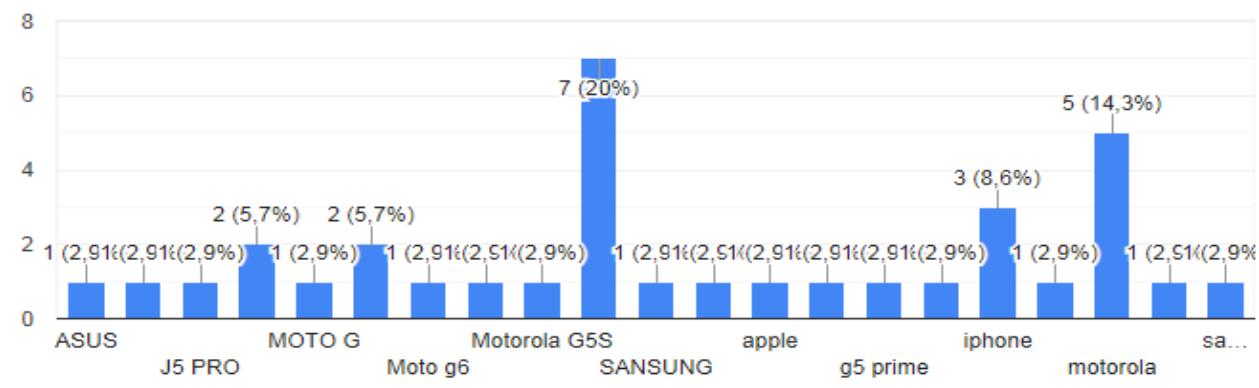

15) Qual a escolaridade da sua mãe?

35 respostas

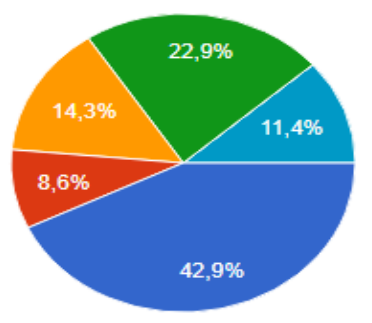

- Ensino Fundamental Incompleto

- Ensino Fundamental Completo

Ensino Médio Incompleto

Ensino Médio Completo

- Ensino Superior Incompleto

- Ensino Superior Completo 
16) Qual a escolaridade do seu pai?

35 respostas

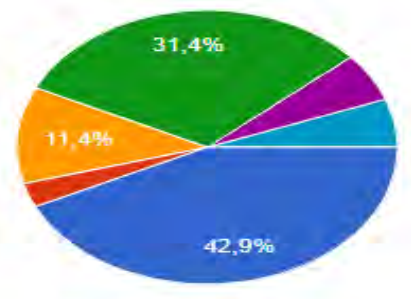

Ensino Fundamental Incompleto

- Ensino Fundamental Completo

- Ensino Médio Incompleto

- Ensino Médio Completo

- Ensino Superior Incompleto

- Ensino Superior Completo

17) Você lê revistas, jornais e livros?

35 respastas

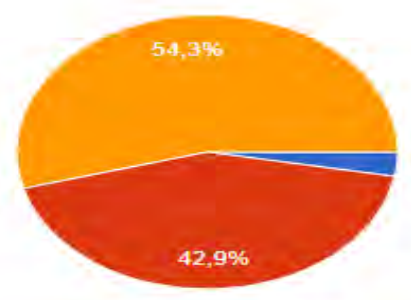

Sempre ou quase sempre

- De vez em quando

- Nunca ou quase nunca

18) Como você ficou sabendo do curso?

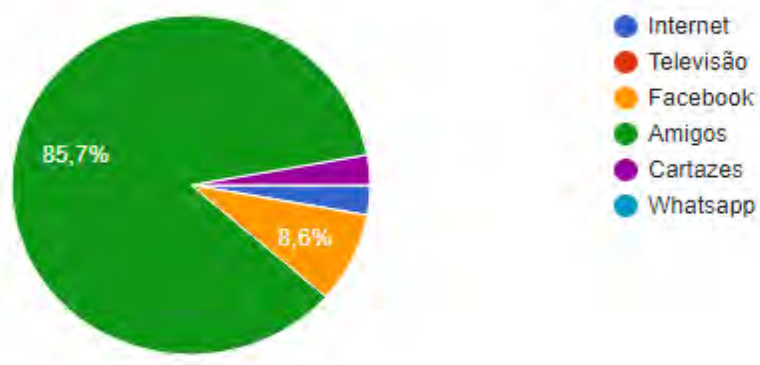

19) Você trabalha ou já trabalhou com propriedades rurais?

35 respostas

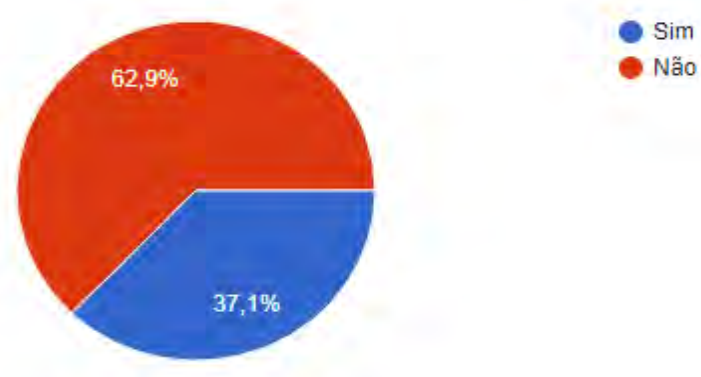




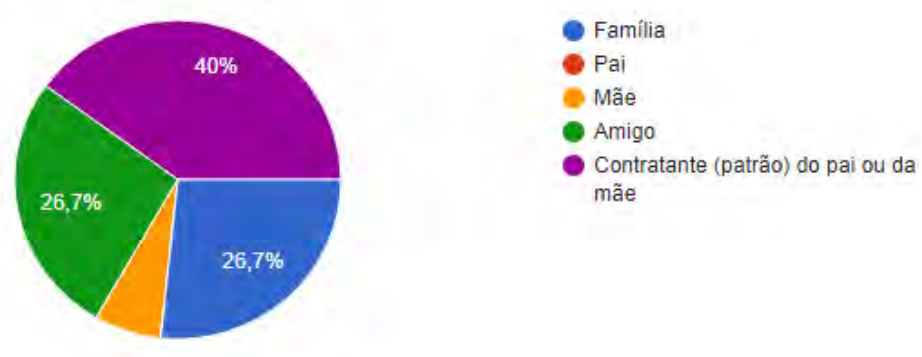

Nesta pesquisa, observa-se que a maioria dos estudantes conheceram o curso por informação de amigos. Ainda, que parte significativa de seus pais (42\%) não terminaram o Ensino Fundamental ou concluíram o Ensino Médio. Possuem celulares de baixo custo, computadores, casa própria, carros populares dado que indica que a grande maioria vem de classe social média baixa, com formação bastante limitada.

Na prática, esses dados, levam a crer, que o perfil da clientela que hoje procura o curso de Ensino Médio Integrado ao Técnico em Agropecuária é um grupo bem específico, voltado para desenvolver trabalhos voltados junto ao setor primário e com procedência familiar de baixa renda e pouca formação formal.

Quanto a questão de gênero, o ingresso se mantem equilibrado. Porém, a cada ano o número de meninas que procuram o curso vem aumentando, levando em consideração que as turmas, no passado, eram massivamente compostas por homens.

\subsection{Análise qualitativa}

Para começar a análise da pesquisa sobre o método qualitativo primeiramente conversou-se com cinco alunos do curso do Ensino Médio Integrado ao Técnico em Agropecuária, interessados em colaborar com a pesquisa, quando estavam cursando a primeira série. A finalidade desse diálogo é acompanhar a progressão do desenvolvimento desses alunos ao longo do curso, entender seus propósitos de escolha e, por último, reavaliá-los na terceira série quanto aos mesmos aspectos.

Com isso, observa se a hipótese contida na pesquisa é pertinente, levando em consideração o objetivo pressuposto em questão sobre o novo perfil dos estudantes que estão matriculados no curso; quanto aos aspectos desenvolvidos no decorrer do ensino aprendizagem, se estão de encontro com os anseios que os motivaram a 
ingressarem na jornada do mercado da Agropecuária, que por sua vez, está ligada ao agronegócio.

Faz-se necessário ressaltar que para a elaboração das perguntas foi usado um vocabulário bastante simplificado e de fácil entendimento, por conta do público estar em processo de aprendizagem. O que em certa medida fica evidenciado, pelos dados oferecidos no SARESP na disciplina de Português e pelas palavras utilizadas pelos estudantes para respostas, que existem certas limitações para entenderem questionamentos feitos com uma linguagem um pouco mais rebuscada.

É importante salientar que as entrevistas dos estudantes aqui reproduzidas, foram, em grande maioria, com questionário escrito, em alguns poucos casos utilizouse gravação de vídeos; e por meio de questões abertas em diálogo estabelecido a partir da aplicação do questionário.

\subsubsection{Entrevistas realizadas com alunos do ETIM em Agropecuária}

O conteúdo a seguir tem por base o questionário aplicado aos alunos da primeira série do ETIM em Agropecuária (Apêndice 1), no mês de setembro de 2016. Para não expor o nome dos alunos participantes dessa entrevista, cada aluno foi identificado com uma letra do alfabeto, sendo: aluno $A$, aluno $B$, aluno $C$.

Aqui foram selecionadas três entrevistas com informações mais relevantes para sustentar essa pesquisa.

\section{Aluno A, da primeira série do ETIM em Agropecuária, setembro de 2016:}

A entrevista foi feita com um aluno que em 2016 cursava a $1^{\text {a }}$ série do curso Técnico em Agropecuária Integrado ao Ensino Médio. Na ocasião, quando questionado sobre o motivo que o levou a matricular-se no curso, o discente alega gostar de animais e quer aprimorar seus conhecimentos: "Porque eu gosto da área de agropecuária, porque eu gosto de animal." (Aluno A). Depois, numa conversa mais informal revelou para entrevistadora (autora da presente pesquisa) que seu avô materno era empregado numa fazenda próxima da sua cidade natal, Tambaú, vizinha de Santa Rita do Passa Quatro. Assim, o fato de passar boa parte da infância brincando com os bichos levou a interessar-se em buscar mais informação sobre a área. 
Ele considera as matérias da área técnica do curso muito boas, e apresentou como justificativa a sua preparação para o mercado de trabalho. A maior dificuldade apontada pelo discente, no curso até o momento da realização dessa entrevista, foi com relação às disciplinas "Química" e "Física".

Quando questionado sobre o que mais gosta no curso e o que acrescentaria, o estudante deixa claro a importância das aulas práticas: "As aulas práticas porque vejo no campo principalmente na matéria microbiologia botânico" (Aluno A). O discente sugere a introdução de mecânica voltada para os equipamentos agrícolas e mais matérias práticas afins, alegando que as já existentes são bastante agregadoras para sua formação, porém existe a necessidade de mais vivência no campo.

Ao ser interrogado sobre o que pretende fazer depois de formado no curso de Agropecuária, o estudante A respondeu: "Formar em agrônomo porque quero atuar na área de silagem e pastagem." Quanto ao seu desempenho nas aulas práticas, o estudante $A$ justifica que oferece o de melhor nessas aulas porque "as aulas práticas também valem nota e pra ser um bom técnico" (Aluno A).

Outro posicionamento do discente de extrema relevância é o fato de estar ainda na primeira série do curso e pré-disposto a dar continuidade aos estudos após a formação no Etim (Ensino Médio Integrado ao curso Técnico em Agropecuária) dentro do eixo, o que levar a crer que a instituição está de acordo com sua aptidão (perfil) e visão futura profissional.

Na pergunta número dez, a perspectiva do discente com relação à formação oferecida pelo curso deixou ainda mais claro que a missão formadora da instituição vai de encontro às suas expectativas. Pois, quando questionado sobre se acha que está se preparando adequadamente para o mercado de trabalho, o mesmo responde que o curso técnico oferece o "preparamento" necessário para atingir o mercado de trabalho.

\section{Aluna B, da primeira série do ETIM, em Agropecuária, da turma de 2018}

Ao ser interrogada por que escolheu o curso de Agropecuária, a aluna B apresenta a seguinte resposta: "Nunca tive tanto contato, com esse mundo, mas sempre gostei, e quando descobri o curso com o ensino médio, e essa oportunidade." Ao contrário do outro entrevistado, a estudante, da turma da primeira série do Etim Agropecuária, 2018, nunca teve contato com a área agrícola, porém, demonstra estar bastante satisfeita e segura com a escolha. 
Ao ser interrogada sobre o que acha das matérias da área técnica do curso, sua resposta é "Bom". Como justificativa apresenta: "Acho que pode melhorar mais, os professores já são ótimos, inteligentes demais, por isso sei que podemos ter mais." (Aluna B). Ao ser questionada sobre qual sua maior dificuldade no curso até agora, a aluna $B$ ressalta que não apresenta dificuldades, mas às vezes se encontra a vontade ou seguro para realizar a atividade.

Quanto à importância das aulas práticas, a estudante B apresenta a seguinte resposta: "Estar mais envolvido, as aulas práticas nos ajudam a entender melhor" (Estudante B). Nas próximas séries do curso ela espera "ter mais contato com os animais, ou seja, espero aprender mais e por em prática." (Aluna B). Também sugere que o curso tenha mais aulas práticas envolvendo contato com os animais.

Após sua formação no curso de Agropecuária, a estudante B pretende continuar trabalhando na área, fazendo curso de Medicina Veterinária pois tem muita afinidade com os professores. O que ela mais gosta no curso são os assuntos voltados aos animais.

Ao ser interrogada sobre as aulas práticas, a estudante B responde que sua participação tem sido "em partes". Como justificativa ressalta: "Sempre tento, mas às vezes não me sinto tão tranquila de realizar algumas coisas e acabo não fazendo." (Estudante B). Ela sente que está se preparando para o mercado de trabalho, mesmo cursando o primeiro ano do curso técnico em Agropecuária.

\section{Aluno C, da terceira serie do ETIM em Agropecuária, ano de 2016.}

Ao ser interrogado por qual motivo escolheu o curso de Agropecuária, o estudante $C$ respondeu que se identifica com a área e sempre gostou do trabalho com animais, plantas e instalações rurais. Na sua concepção, as disciplinas da área técnica do curso são "boas". Como justificativa ressalta que "todas as matérias passam um conhecimento indispensável a qualquer técnico agrícola, mas a explicação de alguns professores ainda pode melhorar."(Aluno $\mathrm{C}$ ).

Ao ser interrogado sobre o que achou do curso até o momento responde "Bom". Justifica sua resposta apontando que aprendeu na prática muitas coisas que ainda não tinha noção com o manejo de hortas e animais, uso de ferramentas etc. Ele considera as aulas práticas de altíssima importância, pois "nessa área o aprendizado só é possível com o uso das mãos e do esforço físico"(Aluno C). 
Ao ser interrogado sobre qual a disciplina que mais gostou, o estudante $\mathrm{C}$ aponta quatro disciplinas, sendo: História, Geografia, sociologia e Filosofia. Como justificativa, ressalta: "Gosto de todas as matérias do curso menos topografia por não dominar matérias exatas, mas a matéria de curso que mais gosto é sanidade de bem estar animal." (Aluno C). Assim sendo, o curso contribuirá para sua vida profissional, pois proporciona experiência para trabalhar em uma propriedade agrícola.

Ao ser questionado sobre o que pretende fazer depois de formado no curso de Agropecuária, o aluno $C$ respondeu que, "caso eu não passe no vestibular vou me dedicar inteiramente ao trabalho com ordenha de gado girolando ou holandês." Ele pretende trabalhar com ordenha ou berçário de animais recém nascidos.

$\mathrm{Na}$ visão do aluno $\mathrm{C}$, a estrutura da escola atende às necessidades do curso: "O lugar é adaptado até para ensinos acadêmicos com grandes áreas para plantio, pastagem, confinamento animal, tratores, pastagem, implementos. Tudo que é necessário ao curso de agropecuária." No entanto, ele considera que está se preparando em partes para o mercado de trabalho, pois sua experiência especifica é com ordenhas mecanizadas, mas para atuar em outros setores dentro de uma propriedade agrícola ainda precisa de mais experiência.

$\mathrm{Na}$ sua perspectiva afirma o que mais falta no curso de Agropecuária são estágios. Como justificativa ele responde que "o estágio especializa o aluno na prática para o trabalho em setores específicos dentro de uma propriedade". (Aluno C). Para melhoria do curso, o aluno $C$ propõe: oferecer mais estágios ao estudante em cada setor da agropecuária, usando os recursos disponíveis em toda escola em prol do aprendizado do aluno, uma vez que a maioria dos recursos existentes na referida escola é utilizada somente para o lucro e não para o ensino didático.

Quando interrogado sobre a sua maior dificuldade no curso, o aluno $\mathrm{C}$ aponta: "Matérias com conceitos exatos como topografia, matemática, física e química." Ao apresentar uma área do curso que gostaria de atuar o aluno $\mathrm{C}$ aponta a agropecuária com manejo animal, ordenha, vacinação e tratamento de doenças de bovinos e suínos.

O segundo estudante entrevistado cursava, em 2016, a terceira série do Etim (Ensino Médio Integrado ao curso Técnico em Agropecuária). Apesar de apresentar uma desenvoltura maior para âmbito das ciências humanas, especificamente a História, também concluiu o questionário e a conversa informal com a entrevistadora dizendo que o curso foi de encontro às suas expectativas e que pretende trabalhar na área, utilizando-se de sua aptidão com o setor agrícola para realizar trabalhos braçais. 
Acredita que para exercer o trabalho agrícola falta mais experiência e para isso sugeriu algumas melhorias no preparo e explicação das aulas práticas com didáticas inovadoras $^{21}$ e mais aulas no campo para vivenciarem mais a rotina de uma propriedade produtiva.

\subsubsection{QUESTIONÁRIO PARA OS ALUNOS DA TERCEIRA SÉRIE, DO ETIM EM AGROPECUÁRIA, TURMA DE 2018}

No ano de 2018, o mesmo questionário foi aplicado aos alunos da terceira série do Ensino Médio Integrado ao técnico em Agropecuária. Na ocasião, a entrevistadora se utilizou não só do instrumento estruturado, mas permitiu espaços para inclusão de questões de forma participativa e os alunos foram se posicionando com mais clareza, oralmente ou por escrito, sobre o que encontraram no curso. Aqui, novamente foram escolhidas duas entrevistas com informações mais relevantes para o caso que se pretende analisar.

Para não expor o nome dos alunos participantes dessa entrevista, eles foram $f$ identificados com uma letra do alfabeto, sendo: aluno $D$ e aluno $E$.

\section{Aluno D, da terceira série do ETIM em Agropecuária, ano de 2018.}

Ao ser interrogado por qual motivo escolheu o curso de Agropecuária, o estudante D respondeu que se identifica com essa área. Ele considera "boas" as matérias da área técnica do curso, pois as "aulas são boas, mas faltam aulas práticas, faltam aulas práticas de mecanização agrícola e reprodução e seleção animal (estar animal)" (Aluno D).

Para ele, o curso foi bom até o momento, pois the forneceu muito conhecimento na área agrícola. Para ele, as aulas práticas são de "total importância, pois precisamos saber executar o que aprendemos nas aulas teóricas, para sair da escola preparados para o campo." (Estudante D).

21 Na parte aberta da entrevista, não somente esse aluno, mas vários outros, reclamaram dos procedimentos didáticos do corpo docente, que já se encontram em idade mais avançada, acima dos 60 anos e, utilizam técnicas de aula bastante engessadas e antiquadas. Todos os estudantes veem a necessidade de renovação dos professores com a contratação de novos para inovar não somente o curso como também a fazenda onde a escola está instalada. 
Ao ser interrogado sobre a disciplina que mais gostou ou gosta, o estudante $D$ respondeu "Mecanização agrícola e reprodução e seleção animal." O curso de Agropecuária contribui com bastante conhecimento teórico e gera experiência para sua vida profissional. Após sua formação no curso de Agropecuária, o estudante $D$ pretende se formar em medicina veterinária ou em algum outro curso relacionado à agricultura, uma vez que pretende trabalhar na área.

$O$ Estudante $D$ também foi interrogado se a estrutura da escola atende às necessidades do curso. Na sua concepção, a escola atende as necessidades do curso pois "tem um ótimo espaço, muita estrutura, porém muitas vezes não é tão bem utilizada." (Estudante D).

Ao ser interrogado se está se preparando adequadamente para o mercado o estudante $D$ responde que, em algumas áreas está preparado, mas tem muito o que aprender, Ihe falta experiência. Ele sente falta no curso de aulas práticas com animais e com máquinas agrícolas. Como melhoria para o curso, o estudante $D$ propõe: "Aumentaria as aulas práticas e aproveitaria melhor os espaços da escola (aprender ao invésde Trabalho )."

Sua maior dificuldade foi no trato com os professores. Além de ser muito tímido, o estudante $D$ alegou a necessidade de inovação do corpo docente, que se encontra com muitos anos de carreira e por esse motivo a didática está ultrapassada.

O estudante $D$ disse que dará continuidade nos estudos com a graduação em Medicina Veterinária ou Pecuária.

Nesta entrevista, o estudante $D$, diz se identificar com a área, por esse motivo procurou o curso e que seu avô paterno possui pequena propriedade rural. Por isso, desde criança sentiu vontade de buscar mais conhecimentos sobre as coisas relacionadas ao campo.

\section{Entrevista aluno E}

Através de um vídeo gravado, foi possível entrevistar o aluno E, o qual cursa o Terceiro Agro e tem dezessete anos de idade. Ele veio para a escola por gostar da Agronomia. Seu avô sempre teve sítio e trabalhou com animais e com a terra. Por isso, veio para escola agrícola para aperfeiçoar os aprendizados de como trabalhar com gados, equinos, aves, ou seja, veio mesmo para aperfeiçoar o seu conhecimento.

Essa era a ideia que ele tinha do curso técnico e quando iniciou seus estudos achou que ia ter bastante coisa. E teve sim bastante coisa diferente das outras escolas. 
Mas na visão dele, "foi a mesma coisa do que as escolas normais porque teve mais aula teórica do que prática desses anos para cá." (Aluno E)

Na visão do aluno, os pontos positivos oferecidos pelo curso são: "Você pode ter bastante convivência com os animais... aprende a administrar bastante coisa, porque tem bastante projeto... aprende a fazer projetos pra melhorar a infraestrutura das propriedades e das empresas que você entrar um dia." Como ponto frágil do curso ele aponta: "Aumento das aulas práticas, porque com a prática você alcança melhor a teoria." (Aluno E)

Segundo o aluno E, as matérias de Zootecnia e Hortaliças devem ter mais aulas, para se ter mais conhecimento. Ele ressalta que o conhecimento adquirido no decorrer do curso agregou valores para sua vida: "[...] serviu para abrir minha cabeça, porque antes era bastante complexo, agora consigo fazer melhor de um jeito, se não dá certo faço de outro bem mais amplo o jeito que aprende aqui." (Aluno E). Portanto, ele espera do mercado de trabalho bastante oportunidade, como justificativa aponta: "[...] essa área de agropecuária, mexer com animais e plantas, está abrindo bastante mercado de trabalho, tem que gostar e querer correr atrás." (Aluno E) Assim sendo, ele pretende seguir uma área específica dentro da Agropecuária, ou seja, Agronomia ou Veterinária. Se fosse atualmente, ele trabalharia na Agronomia em plantações, animais e etc.

Ao ser questionado se alguém o incentivou a fazer esse curso, o mesmo responde que foram seus pais. Mesmo não sendo da área de Agropecuária, mas seu avô por parte de mãe, o incentivou a trabalhar nessa área.

Ao ser interrogado sobre o que ele tem a dizer sobre a Etec, o aluno $\mathrm{E}$ responde: "Abriu bem minha cabeça, conheci coisas e gente que eu nem sabia que existia, ela me deu oportunidade. É "perigoso" você já sair da Etec com emprego se for dedicado."

Observa-se pela linguagem primária do estudante, que a procura pelo curso foi em grande medida motivada pela família, que por sua vez, possui pequena propriedade na cidade vizinha de Tambaú. Ele pretende dar continuidade aos estudos voltados para carreira profissional do eixo da Agropecuária.

Dentro das expectativas criadas a partir dos posicionamentos familiares e pessoais, o discente revela na conversa com a entrevistadora que o curso e seus conteúdos foram de encontro com o que esperava e completou que os conhecimentos ali adquiridos foram melhor do que esperava, abrindo sua visão de mundo, visto que conheceu novos colegas, situações, costumes, condutas que agregaram na construção 
do seu processo de ensino/aprendizagem que levará para prática no mercado de trabalho.

Da mesma maneira que os outros entrevistados, o estudante em questão, aponta a necessidade do aumento do número de aulas práticas, pois esses conhecimentos são de suma relevância na aquisição de experiências vivenciadas. Assim, acredita que certa dose de dedicação poderá levá-lo a oportunidade de sair da escola com possibilidade de emprego.

\subsubsection{Questionário para os professores de matérias técnicas do ETIM, em Agropecuária}

Com relação aos professores das matérias práticas dois deles, se habilitaram a responder o questionário (Apêndice 2). Assim sendo, o conteúdo a seguir traz um relatório das respostas obtidas através dessas entrevistas. Os nomes dos professores não serão divulgados, sendo os mesmos reconhecidos como professor $A$ e professor B.

Com relação às disciplinas ministradas pelos professores $A$ e $B$, foi possível identificar as seguintes disciplinas: Processamento de Produtos Agropecuários, Vivericultura, Nutrição Animal, Mecanização Agrícola, Gestão Ambiental Saúde e Segurança no Trabalho Rural (Professor A); Nutrição vegetal, Microbiologia e Botânica, Plano de Negócios Agropecuários, Fitosanidade, Uso sustentável do solo e da água, TCC (Professor B).

Ambos os professores responderam que a infraestrutura da Etec atende os propósitos das disciplinas de aulas práticas. Como justificativa, o professor A ressalta: "A Etec possui tratores com equipamentos implementos, criação de bovinos, criação de suínos."

Na visão do professor A, o plano do curso é regular, e aponta como justificativa: "O Plano e adequado a formação do Técnico agropecuário." (Professor A). Já o professor B considera o plano do curso muito bom, mas não apresenta justificativas para sua resposta.

Ao serem questionados se mudariam a grade do curso os professores entrevistados apresentaram respostas diferentes. $\mathrm{Na}$ visão do professor $\mathrm{A}$, é importante uma mudança na grade do curso, a fim de realizar adaptações em algumas 
partes. Já, o professor B ressalta que não há necessidade de realizar alterações na grade do curso.

Ao ser interrogado se encontra dificuldades com o perfil do discente do curso, o professor A respondeu "sim"; em sua resposta a "maior dificuldade é a falta de conhecimento básico". Já, o professor B aponta que essas dificuldades são "em partes", porém não justificou sua resposta.

Ao serem interrogados sobre a concepção deles com relação ao aluno que cursa a primeira série do ETIM de Agropecuária, foi possível obter os seguintes pareceres: "Como eles vêm de diferentes formações o maior problema é a adaptação." (Professor A). "Partes dos alunos são desinteressados em alguns conteúdos" (Professor B).

A respeito dos alunos que cursam a segunda e a terceira série do ETIM de Agropecuária, foi possível obter os seguintes posicionamentos: "Ele desenvolve melhor as atividades, pois já está adaptado ao modelo do curso."(Professor A). "Parte dos alunos não tem interesse em alguns conteúdos." (Professor B)

Tanto o professor $A$, quanto o professor $B$, concordam que os alunos saem preparados "em partes" para o mercado de trabalho. Ao serem interrogados se contratariam esses profissionais para trabalhar, ambos responderam "sim". Apenas o professor A apresentou justificativa: "Sim, logicamente escolheria os que melhor se sobre saíram durante o curso." (Professor A).

$\mathrm{Na}$ visão do professor $\mathrm{A}$, os pontos fortes do curso para formação dos alunos são: "As bases tecnológicas abrangem de uma forma qual para experiência em relação ao mercado de trabalho." Segundo o professor B, os pontos fortes são: "Além das disciplinas básicas, a agropecuária é bastante explorada, pelos alunos".

Em relação aos pontos frágeis do curso na formação dos alunos, os entrevistados responderam: "Mais parcerias para a realização de estágios." (Professor A); "Acho que pela falta de interesse por parte dos alunos de modo geral influencia nos conhecimentos profissionalmente" (Professor B).

\subsubsection{Resultados obtidos através de entrevistas com proprietários de terras}

Também foram realizadas entrevistas com proprietários de terras, buscando um melhor esclarecimento sobre a atuação de técnicos em Agropecuária, formados pela Etec. Participaram dessa entrevista dois proprietários de terras, os quais responderam livremente o questionário a eles aplicado (Apêndice 4). O conteúdo a 
seguir obedece a sequência das perguntas apontadas no referido questionário. Os proprietários de terras são identificados como Proprietário A e Proprietário B.

Ao serem questionados se conhecem as escolas Técnicas de Centro Paula Souza, ambos responderam "sim" e ressaltaram que conhecem algum profissional formado no curso Técnico em Agropecuária da Etec.

O proprietário A possui uma propriedade de 30 a 40 hectares. Já, o proprietário B possui uma propriedade com mais de 40 hectares. Ambos já utilizaram, ou utilizam, alguém com formação técnica em Agropecuária para trabalhar em sua propriedade. As propriedades dos referidos entrevistados atuam tanto na área agrícola, quanto agropecuária (Proprietário $A$; Proprietário $B$ ).

Ao serem interrogados sobre a faixa salarial do Técnico em Agropecuária, ambos responderam que varia entre $R \$ 1.700,00$ a $R \$ 2.000,00$ (Proprietário $A$, Proprietário B).

Ao ser questionado sobre o que não pode faltar na formação de um Técnico em Agropecuária, o proprietário A respondeu: "A parte prática é fundamental." Já, na visão do proprietário $B$, não pode faltar na formação de um Técnico em Agropecuária “Interesse, criatividade, competência, responsável e honestidade".

É importante destacar que apenas o proprietário $A$ respondeu à pergunta que se refere ao tipo de profissional que necessita para trabalhar em sua propriedade e quais as aptidões que ele teria para auxiliá-lo. Como justificativa destaca-se: "Que tenha conhecimento prático e que saiba ou tenha conhecimento de um modo atual" (Proprietário A).

Foi possível comprovar que ambos os proprietários utilizam algum tipo de tecnologia em sua propriedade. O proprietário A faz uso de trator, pulverizador e serviços terceirizados. Já o proprietário B utiliza adubação adequada às culturas e colheita mecanizada de cana de açúcar.

\subsection{ANÁLISE GERAL DOS RESULTADOS OBTIDOS}

Perante as respostas oferecidas pelas entrevistas, verificou-se a compatibilidade da proposta inicial do projeto, que é observar o perfil do atual estudante da Etec Manoel dos Reis Araújo a partir de sua ótica. Ou seja, se os recursos pedagógicos oferecidos pela instituição ao longo dos três anos do Ensino Médio Integrado ao Técnico em Agropecuária vão de encontro às suas expectativas. O que se conclui é 
que o estudante que procura o curso está concatenado com as propostas do ensino aprendizagem e que muitos darão continuidade aos estudos, visto que a hipótese do presente trabalho de pesquisa também se comprovou, entendem que seus conhecimentos serão aproveitados no agronegócio.

Através do conteúdo abordado na pesquisa qualitativa é possível ressaltar que todos os alunos que participaram dessa pesquisa se sentiram motivados a cursar o Ensino Técnico em Agropecuária Integrado. Os fatores motivacionais são variam: alguns alunos passaram boa parte da infância brincando com animais, outros alunos porque seus avós são proprietários de imóveis rurais.

Assim, o referido curso contribui para o preparo do futuro profissional para o mercado de trabalho. Foi possível verificar que todos os entrevistados valorizam as aulas práticas. É através das aulas práticas que eles adquirem maior experiência na área agropecuária e se preparam para o mercado de trabalho, o que justifica a importância do trabalho docente nessa área. Inclusive, eles sugerem mais investimentos nas disciplinas práticas, inclusão de novas tecnologias voltadas para o agronegócio.

Outro aspecto que chama a atenção entre os estudantes é o interesse de ingressar em um curso superior voltado para a Agropecuária. Todos eles pretendem dar continuidade aos seus estudos, buscando novos conhecimentos na área agrícola, o que justifica que o ETIM e a estrutura da escola atendem as aptidões (perfil) dos seus estudantes.

Os professores que responderam o questionário (Apêndice 3), possuem mais de 30 anos de trabalhos exercidos dentro da Etec Manoel dos Reis Araújo, oferecendo aos discentes um gama de conhecimentos teórico práticoS.

Ao longo do exercício do magistério a maior queixa dos docentes em questão é justamente o problema enfrentado pela maior parte dos professores na atualidade: a falta de interesse por parte dos alunos, fazendo com que o trabalho pedagógico fique limitado.

Na observação de ambos, a matriz curricular do curso é condizente com a realidade do mercado. Porém, a maior dificuldade, segundo o primeiro entrevistado, é a adaptação do estudante à realidade de uma escola técnica, pois além de não possuírem conhecimentos básicos de todas as matérias, os estudantes demoram a amadurecer com relação aos trabalhos que têm que desempenhar.

Contudo, ao serem questionados se contratariam a mão de obra formada pela instituição, ambos foram prontamente positivos, pois acreditam que 0 ensino 
aprendizagem desenvolvido ao longo dos três anos os capacita para tornarem-se bons profissionais.

Os proprietários de terras que se habilitaram na ajuda dessa pesquisa são possuidores de área rural de médio porte, moradores da cidade de Santa Rita do Passa Quatro, e afirmaram que conhecem o curso e a mão de obra formada pela instituição.

Em suas propriedades utilizam tecnologias tradicionais, como uso de tratores, por exemplo. Quando necessitam de implementos mais sofisticados, devido ao custo ser alto, acabam terceirizando o trabalho para gastarem menos e lucrarem mais.

Os dois disseram que já contrataram e, ainda contratam alunos para trabalhar em suas respectivas propriedades, levando em consideração a tradição da instituição, que há mais de 50 anos vêm oferecendo ensino técnico especializado. 


\section{Considerações finais}

A motivação principal deste presente estudo esteve vinculada ao desejo de contribuir para o aprofundamento dos estudos relacionados com os propósitos da linha de pesquisa do programa de Mestrado Profissional de Gestão e Inovação da Indústria Animal, o agronegócio.

Visto que este tema se compõe dos princípios que constituem os interesses do setor mercadológico do agronegócio, sobretudo em função da relevância que o mesmo conquistou ao longo de sua trajetória para nossa economia brasileira. De forma mais específica, objetivou colaborar para a compreensão da introdução de aprimoramento de mão de obra qualificada, para o melhor atender os anseios da cadeia produtiva, que buscam, cada vez mais, investimentos em projeto inovadores.

Nesse sentido, o estudo proposto nesta pesquisa foi também compreender, se os processos produtivos no campo brasileiro, contam com a formação que os estudantes absorvem no curso do Ensino Médio Integrado ao Técnico em Agropecuária de forma oportuna para o setor.

Para elucidar as finalidades aqui explicitas, observou-se a evolução do ensino profissional agropecuário e como a construção de seu currículo esteve presente na agenda da sociedade e dos governos estadual e federal, tornando-se uma problemática a ser pensada e repensada durante todo o último século, que implicou em reformas políticos pedagógicas para atenderem as questões das demandas sócio econômicas, que não pararam de crescer.

No caso da Etec Manoel dos Reis Araújo dentro de tudo que foi observado, um dado oferecido pelo Plano Anual de Gestão, página 5, chamou bastante a atenção que foi o número de alunos egressos maiores que o de iniciantes.

Posto que por isso, entende-se a existência de um bom aproveitamento do curso por parte dos estudantes com relação aos conteúdos ministrados e, em contrapartida, vem á procura da mão de obra ali formada pelo mercado produtivo. Dessa maneira, conclui-se que mais alunos são atraídos no decorrer do curso, confirmando assim a hipótese da pesquisa, como se vê no Gráfico 5: 


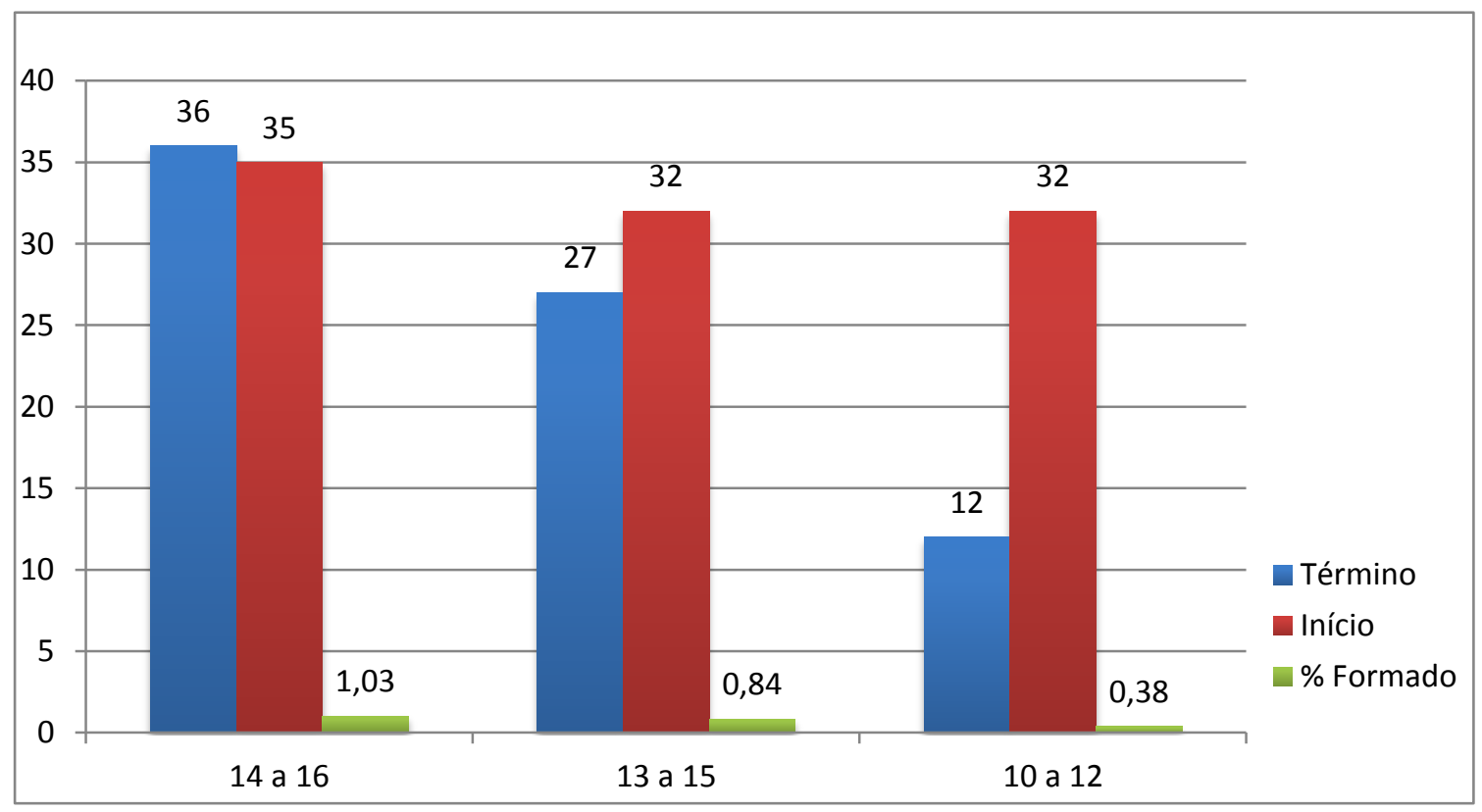

Nas entrevistas feitas com os professores das matérias técnicas e proprietários rurais locais comprovou-se, em grande medida, pelas respectivas falas obtidas, que 0 aprimoramento desses princípios institucionais é muito pertinente para formação dos discentes, que em contrapartida, oferecem trabalhos práticos com maior desempenho e qualidade.

Constatou-se, quantos aos objetivos específicos, que a formação oferecida pelo Plano de Curso da instituição Etec Manoel do Reis Araújo foi de encontro com as expectativas dos estudantes e, por meio das entrevistas, os mesmos transcreveram e afirmaram oralmente que os conhecimento compartilhados no curso foram de acordo com suas expectativas e, em alguns casos, disseram que foi até além do que esperavam. Parte significativa dos estudantes afirmou que pretende dar continuidade aos estudos referentes a agropecuária e estudos afins, em futuras graduações universitárias para aprimorar seus conhecimentos, tendo mais qualificação profissional para seguir atuando nesse ramo profissional.

Nesse contexto, é importante concluir que é relevante continuar investindo em pesquisas destinadas ao agronegócio, pois o mesmo contribui para a formação do Produto Interno Bruto-PIB brasileiro.

O profissional de agronegócio precisa acompanhar a evolução que ocorre no mercado agrícola, pois é dele que depende, em grande medida, como já visto aqui, a economia da nação brasileira e, claro que esse processo só pode encontrar melhora e futuro com os investimentos na educação. 
Assim, sugere que novas pesquisas sejam realizadas nessa área, a fim de comparar os resultados obtidos e traçar novas estratégias para o setor produtivo. 


\section{REFERÊNCIAS BIBLIOGRÁFICAS}

AGRICULTURA NO BRASIL ATUAL. Disponível em: https://mundoeducacao.bol.uol.com.br/geografia/agricultura-no-brasil-atual.htm.

Consultado em 31/08/2018.

ALBUQUERQUE, Marcos Cintra Cavalcante de. Quatro séculos de História econômica brasileira. Disponível em: https://bibliotecadigital.fgv.br/dspace/bitstream/handle/10438/14291/Quatro\%20s\%C3\% A9culos\%20de\%20hist\%C3\%B3ria\%20econ\%C3\%B4mica\%20brasileira.pdf.

Consultado em 23/08/2018.

ARAÚJO, Bruno Mello de. Ensino Agrícola e a Educação. XXVII Simpósio Nacional de História. Conhecimento Histórico e dialogo social. ANPUH. Natal, RN, 22 a 26 de julho de 2013.

BRASIL., Ministério da Educação e do Desporto. Lei № 9.394, de 20/12/96.

estabelece as Diretrizes e Bases da Educação Nacional. Diário oficial(da) República Federativa do Brasil. Brasília, DF, 1996.

Lei Federal n. 9.613 de 20 de agosto de 1946.

CANALI, Heloisa Helena Barbosa. A trajetória da Educação Profissional no Brasil e os Desafios da Construção de um Ensino Médio Integrado à Educação Profissional. Universidade Federal do Paraná. Paraná, 2009.In:www.uepg.br/formped/disciplinas/PoliticaEducacional/CANALI.pdf. Consultado em $21 / 04 / 2017$

CANO, Wilson. Raízes da Concentração Industrial em São Paulo. Rio de Janeiro: Difel, 1977.

Centro Estadual de Educação Tecnológica Paula Souza. Plano de curso atualizado de acordo com a matriz curricular homologada para o $1^{\circ}$ semestre de 2016. Habilitação Profissional de TÉCNICO EM AGROPECUÁRIA INTEGRADO AO ENSINO MÉDIO. Lei Federal n.ำ 9394, de 20-12-1996; Lei Federal n. 11741/2008; Resolução CNE/CEB n. 1, de 5-12-2014; Resolução CNE/CEB n.ำ 6, de 20-9-2012; Resolução CNE/CEB n.․ 2, de 30-1-2012; Resolução CNE/CEB n.․ 4, de 13-7-2010; Resolução SE n.ำ 78, de 7-11-2008; Decreto Federal n.ํ 5154, de 23-7-2004. Plano de Curso aprovado pela Portaria Cetec - 754, de 10-9-2015, publicada no Diário Oficial de 11-9-2015 - Poder Executivo - Seção I - página 54.

COMECON. Disponível em: https://www.estudopratico.com.br/comecon-integracaodas-nacoes-do-leste-europeu/. Consultado em 10/08/2018.

CORRÊA, Vera. A nova cultura do trabalho: subjetividades e novas identidades dos trabalhos. In: FRIGOTTO, Gaudêncio; CIAVATTA, Maria (orgs.). A Formação do 
cidadão produtivo: a cultura de mercado no ensino médio técnico, Brasília: Inep/MECInstituto Nacional de estudos e pesquisas sociais Anísio Teixeira, 2006. P 237-257.

COSTA, Flaviano; CLEMENTE, Ademir; CRUZ, Ana Paula Capuano da; GASSNER, Flavia Pozzera; LOURENÇO, Rosenery Loureiro. Utilização de métodos quantitativos em pesquisa científica: $O$ caso da Associação Brasileira de Custos Disponível em: https://anaiscbc.emnuvens.com.br/anais/article/download/856/856. Consultado em 01/10/2018.

CUNHA, Luís Antônio. $O$ ensino de ofícios nos primórdios da industrialização. São Paulo, Ed. Unesp, Brasília, DF, 2005.

DENARDI, Cláudia Bevilacqua. Ensino superior e o Centro Estadual de Educação Tecnológica Paula Souza (1960-1975). Tese de Doutorado. Campinas: Unicamp, 2014.

DUARTE, Rosalina. Entrevistas em pesquisas qualitativas. Revista educar, p 213225. Editora UFPR. Curitiba, 2004.

FONSECA, Laura Souza, Reestruturação produtiva, reforma do estado e formação profissional no início dos anos de 1990. In: FRIGOTTO, Gaudêncio; CIAVATTA, Maria (orgs.). A formação do cidadão produtivo: a cultura de mercado no ensino médio técnico. Brasília, DF: Inep/MEC-Instituto Nacional de estudos e pesquisas sociais Anísio Teixeira, 2006. p.201-220.

FURTADO, Celso. Formação Econômica do Brasil. São Paulo: Companhia das Letras, edição 34, 2007.

GASQUES, J.G. et al. Desempenho e crescimento do agronegócio no Brasil. Brasília: Instituto de Pesquisa Econômica Aplicada, fev.39p. (IPEA. Texto para discussão, 1009)

GARCIA, Sandra Regina de Oliveira. O Fio da História: A Gênese da Formação Profissional no Brasil. In: www.educacao.rs.gov.br/dados/.../sandra garcia genese form profis.pdf .Consultado em:01/05/2017

GERHARDT, Tatiana Engel, SILVEIRA, Denise Tolfo (org). Método de Pesquisa.1 Edição. Editora UFRGS. Universidade Federal do Rio Grande do Sul, R.S., 2009.

GONCALVES, Walter Vicioni. Mapeamento da Educação Profissional no Estado de São Paulo: Centro Paula Souza e Senai/SP. Imprensa oficial do Estado de São Paulo, 2006.

GRITTI, Silvana Maria. Técnico em Agropecuária: servir à agricultura familiar ou ser desempregado da agricultura capitalista. Tese de Doutoramento defendida na UFRGS, Porto Alegre, 2007. Consultado em 20/04/ 2017.

GÜNTHER, Hartmut. Pesquisa Qualitativa Versus Pesquisa Quantitativa: Esta é a Questão? Universidade de Brasília. Psicologia: Teoria e Pesquisa Mai-Ago 2006, Vol. 22 n. 2, pp. 201-210 
IANNI, O. O estado e o trabalhador rural. Contexto, São Paulo, n. 4, p. 1-15, nov. 1977.

JORNAL ESTADÃO. Disponível em: https://economia.estadao.com.br/noticias/geral,brasil-ja-e-o-terceiro-maior-exportadoragricola-do-mundo,520500. Consultado em 31/08/2018

KUNZE, N. C. Revista Brasileira da educação Profissional e tecnológica/ Ministério da Educação, Secretaria de Educação Profissional e Tecnológica v. 2, №2, (nov. 2009). - Brasília: MEC, SETEC,2009

MANFREDI, S. M, Educação profissional no Brasil. São Paulo: Cortez, 2003.

MELLO, João Manuel Cardoso de. O Capitalismo Tardio: Contribuição à revisão crítica da formação e desenvolvimento da economia brasileira. 2 ed. São Paulo: Editora Brasiliense, 1982.

MENDONÇA, Sonia Regina de. Estado de ensino agrícola no Brasil: da dimensão escolar ao extensionismo-assistencialismo, 1930-1950, Rio de janeiro UFF, 2.006.

MAIA, Luís Carlos Zanirato. Mapeamento das Unidades do Centro Paula Souza 2.014, 2.015, 2.016 e 2.017. CEETEPS, SP

MINISTÉRIO DA EDUCAÇÃO. Educação Profissional Técnica de Nível Médio Integrada ao Ensino Médio. Documento Base. Brasília, dezembro de 2007.

MINISTÉRIO DA EDUCAÇÃO. Diretrizes Curriculares Nacionais para a Educação Profissional Técnica de Nível Médio em Debate. In:http://portal.mec.gov.br/index.php?option=com docman\&view=download\&alias=6695 -den-paraeducacao-profissional-debate\&ltemid=30192

MINISTÉRIO DA EDUCAÇÃO. Catálogo Nacional dos Cursos Técnicos. Brasília: MEC: 2008. Eixo Tecnológico: "RECURSOS NATURAIS" (site: http://www.mec.gov.br/)

MOLINA, Rodrigo Sarruge. História da Educação Agrícola no século XIX: formação gerencial e operária do trabalhador.www.histedbr.fe.unicamp.br/acer histedbr/jornada/jornada9/ files/pUHrQ5 Z8.doc. Consultado em 01/05/2017.

MORAES, C.S.V.; J.F (orgs.). Contribuição à pesquisa do ensino técnico no estado de São Paulo: inventário de fontes documentais. São Paulo: Centro Paula Souza, 2002.

MORAES, C.S.V.;ALVES, J.E (orgs). Escolas profissionais públicas do estado de São Paulo: uma história em imagens( álbum fotográficos).São Paulo: Cento Paula Souza. 2002.

OLIVEIRA, Cristiano Lessa de. Um apanhado teórico-conceitual sobre a pesquisa qualitativa: Tipos, técnicas e Características. Disponível em: http://erevista.unioeste.br/index.php/travessias/article/view/3122. Consultado em: 01/01/2018. 
PACHECO, Eliezer (org). Perspectivas da Educação Profissional Técnica de Nível Médio: Proposta de Diretrizes Curriculares Nacionais. São Paulo: Editora Moderna, 2012.

PERECIN, Marly Therezinha Germano. Os Passo do Saber: A Escola Agrícola Prática Luiz de Queiroz. São Paulo: Edusp, 2.004.

PETEROSSI, H. G., Araújo, A. M, Políticas públicas de educação profissional: uma reforma em construção no sistema de escolas técnicas públicas em São Paulo. In: SEVERINO, A.J.; FAZENDA, I. C. A. (Orgs.) Políticas educacionais: o ensino nacional em questão. Campinas: Papirus, 2003.

PLANO MARSHALL. Disponível em: https://mundoeducacao.bol.uol.com.br/geografia/plano-marshall.htm. Consultado em: $10 / 08 / 2018$

Plano Plurianual de Gestão 2018-2022 da Etec Manoel dos Reis Araújo Santa Rita do Passa Quatro- SP. Disponível em: http://www.etecsantarita.com.br/Anexos/PPG083.pdf. Consultado em 25/06/2018.

PRADO JÚNIOR, Caio. "Contribuição para a Análise de questão agrária no Brasil e "Nova Constituição para a Análise d questão agrária no Brasil", artigos publicados originalmente em 1960 e 1962 na Revista Brasiliense e reproduzidos na coletânea do Autor, A Questão Agrária, São Paulo, Brasiliense, 1979.

PRADO JR., Caio. Formação do Brasil Contemporâneo. São Paulo: Companhia das Letras, 2011.

PRADO JR., Caio. História Econômica do Brasil. São Paulo: Brasiliense,1969.

QUEIROZ, Maria Isaura Pereira. Cultura, Sociedade Rural, Sociedade Urbana no Brasil. Edusp, São Paulo, 1978.

RAMOS, Paulo Bertolucci. Priorização de ideias inovadoras em projetos no agronegócio por meio de modelo de apoio à dedicação multicritério: Estudo de caso "Startup in School" Dissertação de Mestrado. FZEA - USP, Pirassununga, 2017.

ROMANELLI, Otaíza de Oliveira. História da educação no Brasil (1930/1973), 26 ed. Petrópolis: Vozes, 2001.

SACILOTTO, Jose Vitorio. A educação profissional na agenda de políticas públicas de educação no Estado de São Paulo e a expansão do Centro Estadual de Educação Tecnológica Paula Souza. Tese de doutorado. Disponível em: http://repositorio.unicamp.br/jspui/bitstream/REPOSIP/321566/1/Sacilotto JoseVitorio D.pdf. Consultado em: 01/07/2018

SANTILLI, Juliana. Agrobiodiversidade e Direitos dos Agricultores. Editora Petrópolis. 1 Edição. São Paulo, 2009. 
SARESP. Disponível em: http://www.educacao.sp.gov.br/saresp. Consultado em: 01/10/218.

SAVIANI, D. História da História da Educação no Brasil: Um balanço prévio e necessário. EccoS, São Paulo, v.10, № especial, p. 150-151, 2008.

SAVIANI, D. Pedagogia histórico-crítica: primeiras aproximações. 11. ed. São Paulo: Autores Associados/Cortez, 2013.

SILVA, Késia Aparecida Teixeira; CAPPELLE, Mônica Carvalho Alves. A Teoria da Subjetividade e a Epistemologia Qualitativa de Gonzalez Rey como possibilidade Teórico-Metodológica nos Estudos de Administração. IV Encontro de Ensino e Pesquisa em Administração e Contabilidade. Brasília/DF - 3 a 5 de novembro de 2013.

SILVA, Marta Leandro da. A avaliação Institucional das Escolas Técnicas do Centro Paula Souza (1997-2007). Tese de Doutorado apresentada ao Programa de Pós-Graduação em Educação da Universidade Federal de São Carlos, como parte dos requisitos para a obtenção do título de Doutor em Educação - Área de concentração em Fundamentos em Educação. São Carlos, 2008.

SILVA, Marta Leandro da; MARQUES, Waldemar. A trajetória política e históriconormativa do ensino técnico da área de agropecuária no estado de São Paulo: a história política de transição por decretos (de 1882 a 2001). Disponível em: https://periodicos.fclar.unesp.br/rpge/article/view/9362. Consultado em 01/01/2018.

SILVA, Nivaldo Pereira da. Agronegócio: Contribuição nos processos de produção. Monografia apresentada como exigência final do curso de especialização em gestão industrial (conhecimento e inovação), sob orientação do Professor Dr. Antônio Carlos de Francisco. Universidade Tecnológica Federal do Paraná, Campus Ponta Grossa. Paraná, 2007.

SOBRAL, Francisco José M. Retrospectiva histórica do ensino agrícola no Brasil. 2009. Disponível em: http://www2.ifrn.edu.br/ojs/index.php/RBEPT/article/view/2953. Consultado em 01/08/2018

SPINK, M.J.; MENEGON, V.M. A pesquisa como prática discursiva. In: Práticas discursivas e produção de sentidos no cotidiano: aproximações teóricas e metodológicas. Rio de Janeiro: Cortez, 2013. P.42-70.

SZMRECSÁNYI, Tamás. Pequena História da Agricultura no Brasil: do escravismo ao trabalho livre estrutura agrária e Relações de trabalho para onde vai a Agroindústria? Editora Contexto, São Paulo, 1990.

Teles, Tereza Cristina; IOKOI, ZILDA Marcia Gricoli. Campus da USP de Pirassununga: Memória e História. Edusp. São Paulo, 2005

TORESAN, Luiz. Marketing e agribusiness. Disponível em :www.ufsc.com. Acessado em: 26/04/2018.

ZYLBERSZTAJN, D. Conceitos gerais, evolução e apresentação do sistema agroindustrial. In. Gestão dos negócios agroalimentares: Indústria de alimentos, 
indústria de insumo, produção agropecuária. Décio Zylbersztajn \& Marcos Fava Neto (org.). São Paulo: Pioneira,2000

ZOTTI, S.A. Sociedade, educação e currículo no Brasil: dos jesuítas aos anos de 1980. Campinas, SP: Autores Associados; Brasília, DF: Plano, 2014. 240 p. 


\section{Apêndices}

\section{Apêndice 1}

\section{QUESTIONÁRIO PARA OS ALUNOS DA PRIMEIRA SÉRIE DO ETIM EM AGROPECUÁRIA}

1) Por que você escolheu o curso de Agropecuária?

2) O que você acha das matérias da área técnica do curso?

( )MB ( )B ( ) R ( )I

Justifique

3) Qual a sua maior dificuldade no curso até agora?

4) Pra você qual é a importância das aulas práticas?

5) O que você espera aprender nas próximas séries do curso?

6) O que você gostaria que tivesse no curso e não tem?

7) O que você pretende fazer depois de formado no curso de Agropecuária?

8) O que você mais gosta no curso? 
9) Você tem oferecido o seu melhor nas aulas práticas?

( ) SIM NÃO ( ) ( ) EM PARTES

JUSTIFIQUE

10) Você acha que está se preparando adequadamente para o mercado de trabalho?

( ) SIM ( ) NÃO ( ) EM PARTES

Justifique

\section{Apêndice 2}

QUESTIONÁRIO PARA OS ALUNOS DA TERCEIRA SÉRIE DO ETIM EM

AGROPECUÁRIA

1) Por que você escolheu o curso de Agropecuária?

2) O que você acha das matérias da área técnica do curso?

( )MB ( ) B ( ) R ( ) I

Justifique

3) O que você achou do curso até o momento?

4) Pra você qual é a importância das aulas práticas?

5) Qual a disciplina que você mais gostou ou gosta? 
6) Qual a contribuição que o curso dará na sua vida?

7) O que você pretende fazer depois de formado no curso de Agropecuária?

8) Você pretende trabalhar na área?

9) A estrutura da escola atende as necessidades do curso? ( ) SIM NÃO ( ) ( ) EM PARTES Justifique

10) Você acha que está se preparando adequadamente para o mercado de trabalho?

( ) SIM ( ) NÃO ( ) EM PARTES Justifique

11)O que você sente falta no curso?

12)O que você melhoraria no curso?

13)Qual é a sua maior dificuldade no curso? 
14)Se você pudesse escolher, qual a área do curso que você gostaria de atuar?

Apêndice 3

\section{QUESTIONÁRIO PARA OS PROFESSORES DE MATÉRIAS TÉCNICASDO ETIM EM AGROPECUÁRIA}

1) Qual é disciplina que você ministra?

2) A infraestrutura da Etec está adequada para exercer os propósitos das disciplinas de aulas práticas? ( ) SIM ( ) NÃO ( ) EM PARTES Justifique

3) Como você avalia o Plano de Curso?

( )MB ( ) B ( ) R ( ) I

Justifique

4) Você mudaria a grade do curso?

( ) SIM ( ) NÃO ( ) EM PARTES

Oque?

5) Você tem dificuldade com o perfil do discente do curso?

( ) SIM ( ) NÃO ( ) EM PARTES

Quais?

6) Como é o aluno da primeira série do Etim de Agropecuária? 
7) Como é o aluno da segunda e terceira série?

8) Você acha que o aluno sai preparado para o mercado de trabalho? ( ) SIM ( ) NÃO ( ) EM PARTES

9) Você o contrataria?

( ) SIM ( ) NÃO

Justifique

10)Quais os pontos fortes do curso para a formação do aluno?

11)Quais os pontos frágeis do curso da formação do aluno?

Apêndice 4

QUESTIONÁRIO PARA OS PROPRIETÁRIOS DE TERRAS

1) Você conhece as escolas Técnicas do Centro Paula Souza?

( ) SIM ( ) NÃO

2) Você conhece algum profissional formado no curso Técnico em Agropecuária da Etec? 

( ) SIM ( ) NÃO

3) Qual o tamanho da sua propriedade?

( ) até 10 hecares

( ) 10 a 20 hectares

( ) 20 a 30 hectares

( ) 30 a 40 hectares

( ) mais de 40 hectares

4) Você já utilizou ou utiliza alguém com formação técnica em Agropecuária para trabalhar em sua propriedade?

( ) SIM ( ) NÃO

5) Qual a faixa salarial do Técnico em Agropecuária?

() $\mathrm{R} \$ 800,00$ a $\mathrm{R} \$ 1.000,00$

( ) $\mathrm{R} \$ 1.000,00$ a $\mathrm{R} \$ 1.200,00$

( ) $\mathrm{R} \$ 1.200,00$ a $\mathrm{R} \$ 1.500,00$

( ) $\mathrm{R} \$ 1.500,00$ a $\mathrm{R} \$ 1.700,00$

( ) $\mathrm{R} \$ 1.700,00$ a $\mathrm{R} \$ 2.000,00$

6) Sua propriedade é Agrícola ou pecuária?

7) O que não pode faltar na formação de um Técnico em Agropecuária?

8) Qual é o tipo de profissional que você necessita para trabalhar na sua propriedade? Quais as aptidões ele teria que ter para auxiliá-lo?

9) Você utiliza algum tipo de tecnologia em sua propriedade?

( ) Sim -

Qual?

( ) Não 


\section{Apêndice 5}

\section{QUESTIONÁRIO SÓCIOECONOMICO APLICADO AOS ALUNOS QUE PARTICIPARÃO DO PROCESSO DA PESQUISA.}

1) Sexo?

( ) feminino ( ) masculino

2) Como você se considera?
( ) branco ( ) preto ( ) indígena
( ) pardo ( ) amarelo

3) Qual é o mês do seu aniversário?

4) Em que ano você nasceu?

5) Na sua casa tem televisão?
( ) sim, uma
( ) sim, duas
( ) sim, três ou mais ( ) não tem

6) Na sua casa tem radio?
( ) sim, uma
( ) sim, duas
( ) sim, três ou mais ( ) não tem

7) Na sua casa tem DVD?

( ) $\operatorname{sim}($ ) não

8) Na sua casa tem geladeira?

( ) $\operatorname{sim}$ ( ) não

9) Sua casa é própria?

( ) $\operatorname{sim}($ ) não

10)Quantas pessoas moram na sua casa contando com você?

11) Na sua casa tem carro?
( ) sim, um
( ) sim, dois
( ) sim, três ou mais ( ) não tem

12) Na sua casa tem computador?
( ) sim, um
( ) $\operatorname{sim}$, dois
( ) sim, três ou mais ( ) não tem 
13) Na sua casa tem internet?

( ) $\operatorname{sim}($ ) não

14) Você tem celular?

( ) sim ( ) não

Modelo?

15) Qual a escolaridade da sua mãe?

( ) Ensino Fundamental Incompleto ( ) Ensino Fundamental Completo

( ) Ensino Médio Incompleto ( ) Ensino Médio Completo

( ) Ensino Superior Incompleto ( ) Ensino Superior Completo

16) Qual a escolaridade do seu pai?

( ) Ensino Fundamental Incompleto ( ) Ensino Fundamental Completo

( ) Ensino Médio Incompleto ( ) Ensino Médio Completo

( ) Ensino Superior Incompleto ( ) Ensino Superior Completo

17) Você lê revistas, jornais e livros?

( ) sempre ou quase sempre

( ) de vez em quando

( ) nunca ou quase nunca

18) Como você ficou sabendo do curso?

( ) internet

( )Televisão

( ) Facebook

( ) Amigos

( ) Cartazes

( ) Whatsapp

19) Você trabalha ou já trabalhou com propriedades rurais?
( ) Sim
( ) Não

20) Caso sim na pergunta anterior, de quem era essa propriedade?

( ) família

( ) pai

( ) mãe

( ) amigo

( ) contratante ( patrão) do pai ou da mãe 


\section{ANEXO}

Centro Estadual de Educaçäo Tecnolónica Paula Souza

Governo do Esiado de Sáo Paulo

Rua dos Andradas, 140 - Santa lfigénia - CEP 01208-000 - Sso Paulo - SP

\section{ANEXO II MATRIZES CURRICULARES ATUALIZADAS}

\section{a) Sem Espanhol}

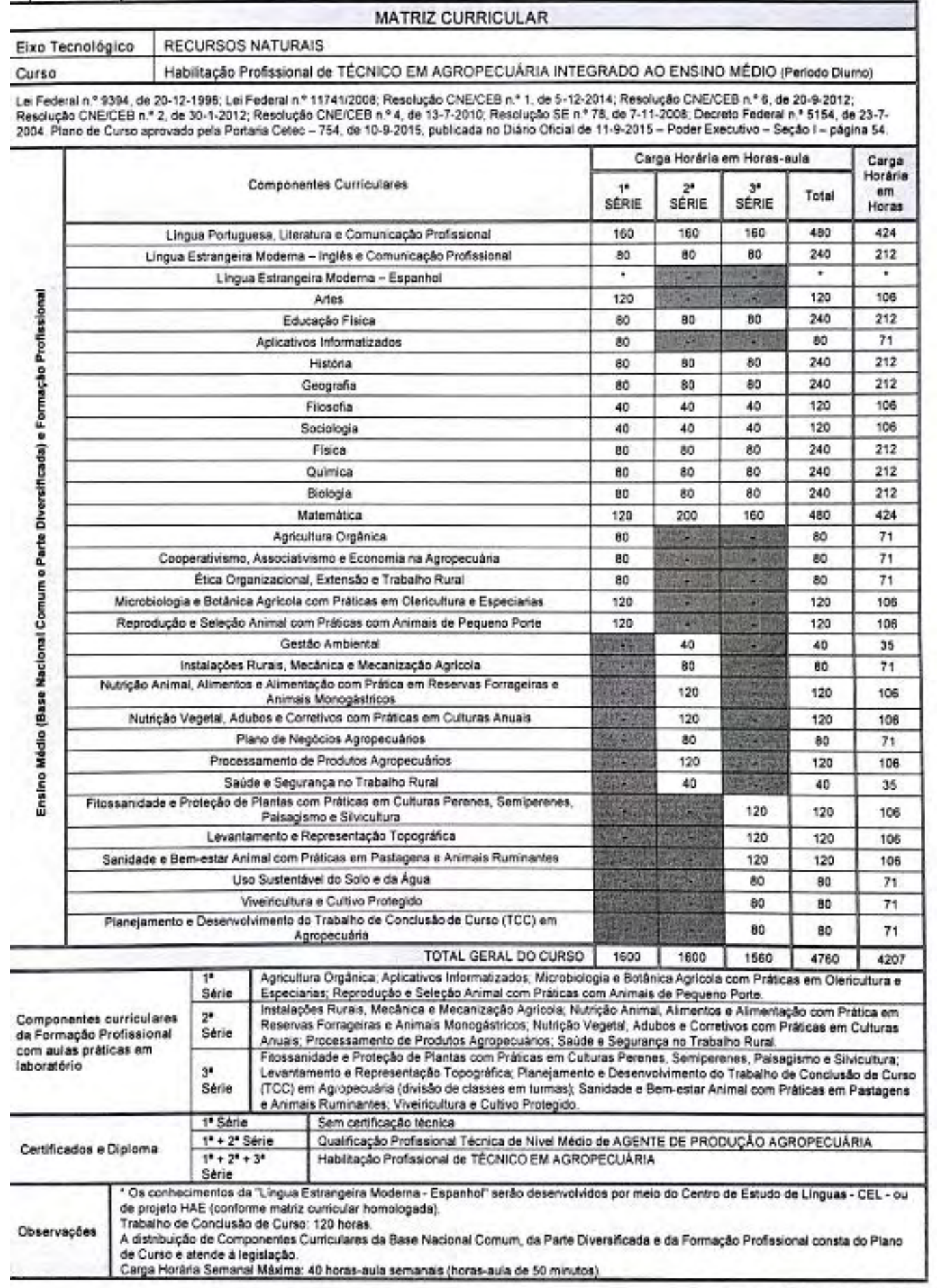

